\title{
THE FOSSIL STALK-EYED CRUSTACEA OF THE PACIFIC SLOPE OF NORTH AMERICA
}

\author{
By Mary J. Rathbun \\ Associate in Zoology, United States National Museum
}

\section{INTRODUCTION}

Some years ago Prof. Bruce L. Clark, of the University of California, sent me for study a collection of Oligocene crabs obtained in Washington and Vancouver Island by Harold Hannibal for Stanford University. The material proved so interesting that an effort was made to gather together all the fossil decapod Crustacea from the Pacific slope which were scattered in museums and in private collections.

Among the contributors besides the University of California were the following: The University of Oregon, through Dr. Earl L. Packard; the University of Washington, through Dr. Charles E. Weaver and Dr. Katherine Van Winkle Palmer; the California Academy of Sciences, through Dr. B. W. Evermann and Dr. G. Dallas Hanna; Stanford University, through Mrs. Ida S. Oldroyd; the San Diego Society of Natural History, through Mrs. Kate Stephens; the Academy of Natural Sciences, Philadelphia, through Dr. H. A. Pilsbry; the Yale University Museum, through Dr. Charles Schuchert; the Provincial Museum, Victoria, B. C., through F. Kermode and Dr. C. F. Newcombe; T. S. Oldroyd, Palo Alto, California; Dr. F. C. Clark, Santa Monica, California; Marcus A. Hanna, University of Washington; Oscar Gorrell, principal of the public schools, Sutherlin, Oregon; and R. H. Palmer, Palo Alto, California.

The collections in the National Museum also were placed at my disposal. These consist chiefly of material transferred by the United States Geological Survey, and obtained by Chester W. Washburne and other geologists, among them Dr. J. C. Schenk, Dr. Ralph Arnold, Robert Anderson, Dr. J. S. Diller, H. J. Karstner, Dr. G. C. Martin, and Dr. L. F. Noble. Other contributors to the museum collection are C. R. Orcutt and Frank Stephens.

Aside from the work done by Woodward and Whiteaves on the British Columbia Cretaceous, very little has been written about the fossil Crustacea of the Pacific slope. (See Bibliography, pp. 138-140.) 
Therefore it is not surprising that the accumulated material yielded 91 species, of which 54 are described as new. In order to make this report complete for the region involved, those species described by Woodward, Whiteaves, and Gabb have been included in the list. This brings the total number of known species for the West Coast up to 105 . The area covered extends from the oil fields of Alaska (Controller Bay region) to the northern part of Lower California, and embraces the Cretaceous, Tertiary, and Pleistocene.

Fossil remains of Crustacea are rare. Their shells are so fragile that they are easily destroyed. Only the hardest parts, such as the chelae, the terminal articles of the walking legs, and less often the sternum are ordinarily preserved. Entire specimens of the body with attached appendages are seldom found except singly in the interior of concretions.

To such concretions is due the preservation of more than 200 specimens of Zanthopsis vulgaris. This appears to have been the common crab of the Oligocene in British Columbia, Washington, and Oregon, and has no counterpart at the present day. The average size varies from about $11 / 2$ to 2 inches across the back and in one case reaches 3 inches. The largest nodule measures 19 centimeters in its greatest diameter and weighs $111 / 2$ pounds. The species forms a third of the bulk of Pacific material examined.

The next most abundant species represented is a fresh-water crayfish from eastern Oregon and southwestern Idaho, Astacus chenoderma. A mass of material from the Yale Museum demonstrates the identity of this species with $A$. breviforceps Cope, which was founded on the smaller of a pair of asymmetrical chelae.

Worthy of note is the prevalence of members of the family Raninidae beginning with the Eocene. The family is not now living on the west coast of America north of Mexico.

Two species of Stomatopoda are here described, the first to be found fossil in America.

In the several lists which follow are given not only the new discoveries and the extent of the relationships of the various species but also a summary of their geologic occurrence. The manuscript was submitted to Prof. Bruce L. Clark and Miss Nellie M. Tegland, research assistant in paleontology at the University of California, who have corrected the horizons according to the latest researches. In spite of the number of species it is to be regretted that the paucity of material makes it impossible to draw any broad general conclusions.

In order to render this paper of the greatest possible use to interested workers, brief characterizations of the major groups have been introduced.

For full data regarding the various specimens, see under list of localities, pages 11 to 22 . 
FOSSIL STALK-EYED CRUSTACEA OF THE PACIFIC SLOPE OF NORTH AMERICA

Pugettia producta (Randall)

Pugettia richii Dana

Scyra acutifrons Dana_________-_ 24

Loxorhynchus grandis Stimpson____________ 24

Loxorhynchus crispatus Stimpson_________ 25

Chorilia, species, Rathbun

Libinia setosa Lockington

Mesorhoea idae, new species___._. 27

Heterocrypta occidentalis (Dana) $\quad 28$

Uca oldroydi, new species_______ 29

Uca hamlini, new species________ 30

Archaeopus antennatus Rathbun_._._._. 31

Hemigrapsus, species, Rathbun___ 32

Hemigrapsus nudus (Dana)

Hemigrapsus oregonensis (Dana) 33

Pinnixa eocenica, new species___ 34

Plagiolophus weaveri, new species______________ 35

Plagiolophus vancouverensis Woodward_______ 37

Pilumnoplax carmanahensis, new species_..___________ 38

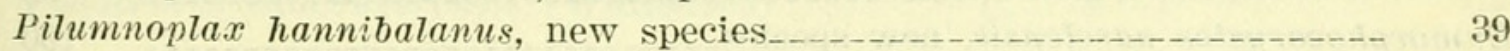

Pilumnoplax soledadensis, new species________ 41

Branchioplax washingtoniana Rathbun____ 42

Eucrate martini, new species____._. 44

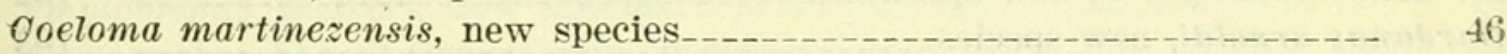

Zanthopsis vulgaris, new species_________._. 48

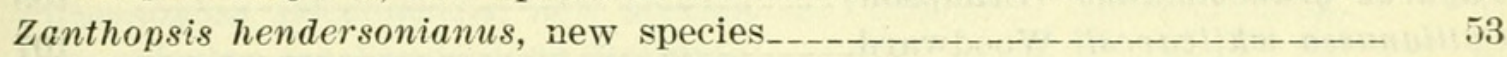

Zanthopsis sternbergi, new species______- 54

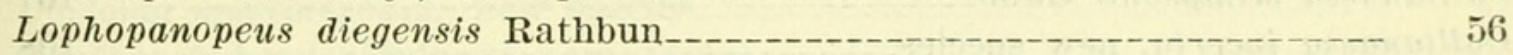

Lophopanopeus leucomanus (Lockington) _-______._. 56

Lophopanopeus lockingtoni Rathbun____._._. 57

Lophopanopeus olearis, new species_________ 57

Cycloxanthops novemdentatus (Lockington) _-________ 58

Cancer gabbi, new species_____ 59

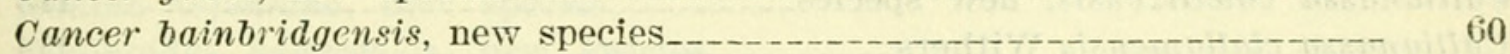

Cancer fissus Rathbun

Cancer urbanus Rathbun___________________ 61

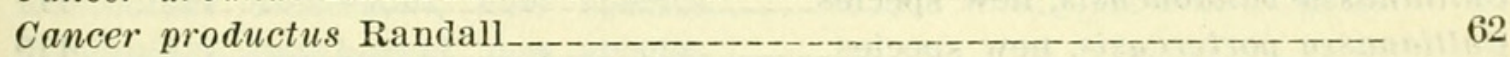

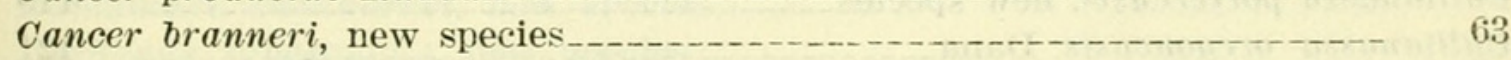

Cancer anthonyi Rathbun_._. 64

Cancer jordani Rathbun

Cancer magister Dana__._. 64

Cancer gracilis Dana________._._. 65

Branchiolambrus altus Rathbun 
Carcinides minor, new species

Portunites triangulum, new species

Portunites insculpta, new species

Portunites alaskensis, new species

Poriunus (Portunus) xantusii (Stimpson)

Callinectes bellicosus (Stimpson)

Randallia ornata (Randall)

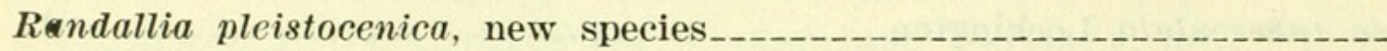

Persephona bigranulata, new species__._.

Calappa lanensis, new species.

Mursia yaquinensis, new species

Mursia marcusana, new species.

Hepatus lineatus Rathbun.

Necrocarcinus hannae, new species

Homolopsis richardsoni Woodward

Palehomola gorrelli, new genus and species._-___-

Graptocarcinus (?), species, Rathbun_______-__-

Ranina tejoniana, new species_____

Ranina americana Withers

Raninoides vaderensis, new species__._.

Raninoides lewisanus, new species

Raninoides dickersoni, new species

Raninoides washburnei, new species

Raninoides eugenensis, new species

Raninoides fulgidus, new species

Raninoides asper, new species

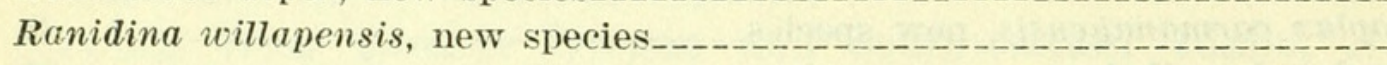

Eumorphocorystes naselensis, new species___________________ 100

Palaeocorystes harveyi Woodward________- 101

Paguristes, species, Rathbun___ 102

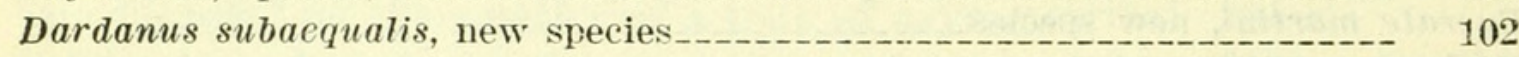

Dardanus arnoldi, new species_____ 103

Pagurus granosimanus (Stimpson) _-_______-_ 105

Callianassa whiteavesii Woodward__________ 107

Callianassa stimpsonii Gabb_________ 107

Callianassa incerta, new species_______________ 108

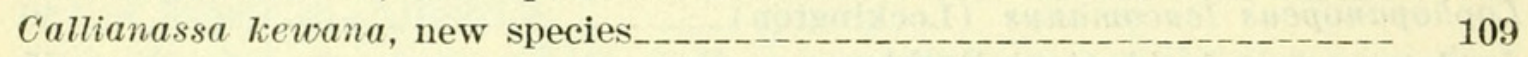

Callianassa fresnoensis, new species______________ 109

Callianassa umpquaensis, new species________ 110

Callianassa knapptonensis, new species__ 112

Callianassa cowlitzensis, new species_____________________ 113

Callianassa clallamensis Withers____________ 114

Callianassa twinensis, new species_________________________ 115

Callianassa bandonensis, new species_________________ 118

Callianassa porterensis, new species___________- 119

Callianassa oregonensis Dana_________ 121

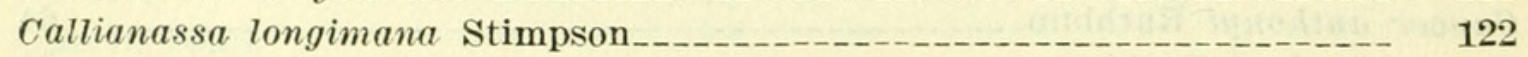

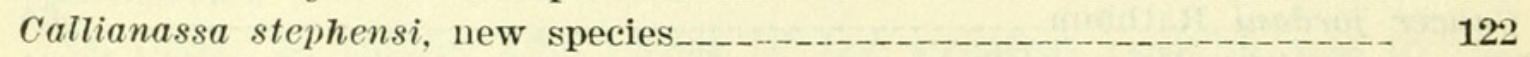

Upogebia (Upogebia) eocenica, new species_____________ 124

Blepharipoda brucei, new species___ 126

Eryma dawsoni Woodward______________ 128

Enoploclytia minor Woodward_____ 128 
Meyeria (?) harveyi Woodward

Page

Hoploparia bennetti Woodward

129

129

Hoploparia (?), species (Gabb)

129

Astacus chenoderma Cope.

Glyphea, species, Whiteaves

130

134

Podocratus canadensis (Whiteaves) - 134

Podocratus vancouverensis (Whiteaves) _._._._- 135

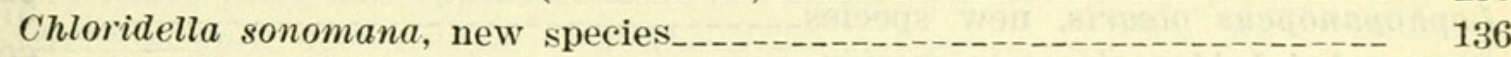

Pseudosquilla adelaidensis, new species_____________ 137

\section{SPECIES ARRANGED ACCORDING TO AGE ${ }^{1}$}

CRETACEOUS

Archaeopus antennatus Rathbun_._. 31

Plagiolophus vancouverensis Woodward__________________________-_ 37

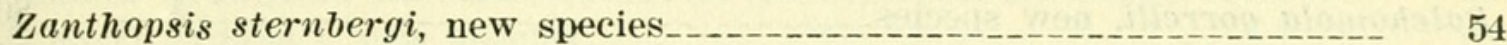

Homolopsis richardsoni Woodward

Callianassa whiteavesii Woodward

(?) Callianassa stimpsonii Gabb__________ 107

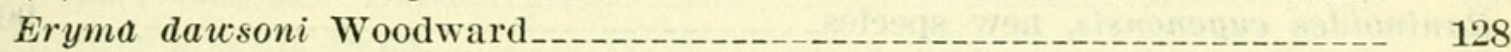

Enoploclytia minor Woodward__. 128

Meyeria ? harveyi Woodward__ 129

Hoploparia bennetti Woodward____________ 129

Hoploparia (?), species (Gabb)

Glyphea, species, Whiteaves__- 134

Podocratus canadensis (Whiteaves) - 134

Podocratus vancouverensis (Whiteaves)

EOCENE

Pinnixa eocenica, new species_____- 34

Plagiolophus weaveri, new species__________ 35

Pilumnoplax hannibalanus, new species____________- 39

Pilumnoplax soledadensis, new species____________._. 41

Branchioplax washingtoniana Rathbun

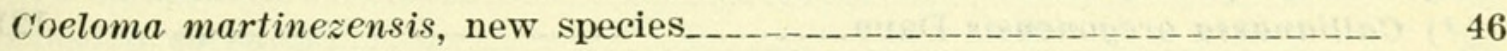

Zanthopsis hendersonianus, new species ____________ 53

Cancer gabbi, new species______._. 59

Carcinides minor, new species.__._. 66

Portunites insculpta, new species._- 71

Necrocarcinus hannae, new species

Ranina tejoniana, new species___._. 90

Raninoides vaderensis, new species

Raninoides lewisanus, new species

Raninoides dickersoni, new species

Raninoides washburnei, new species

Dardanus subaequalis, new species____ 102

(9) Callianassa stimpsonii Gabb_____ 107

Callianassa incerta, new species______ 108.

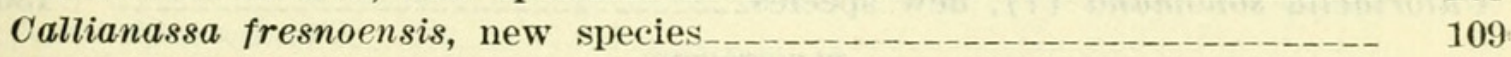

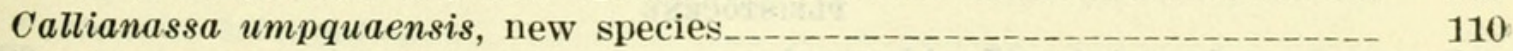

Callianassa cowlitzensis, new species.___________ 113.

Upogebia (Upogebia) eocenica, new species______ 124

1 Those species prefixed by a * are still living. 
OLIGOCENE

Pilumnoplax carmanahensis, new species

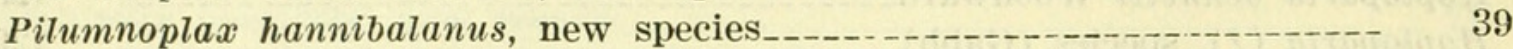

Branchioplax washingtoniana Rathbun___._.................... 42

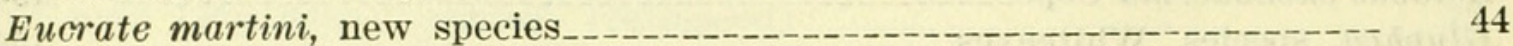

Zanthopsis vulgaris, new species____._._. 48

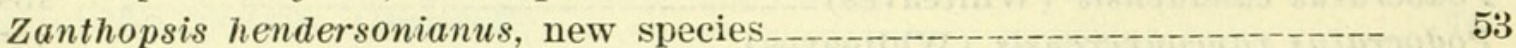

Lophopanopeus olearis, new species___._._._. 57

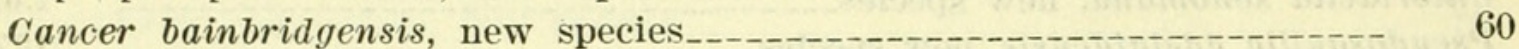

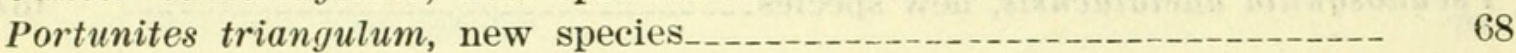

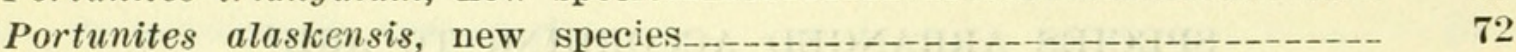

Persephona bigranulata, new species._______

Calappa lanensis, new species_______- 79

Mursia yaquinensis, new species____ 81

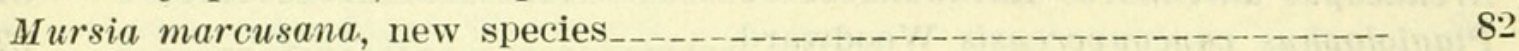

Palehomola gorrelli, new species______._._._._. 86

Graptocarcinus (?), species, Rathbun _._._._._._. 88

Ranina americana Withers_____________._. 91

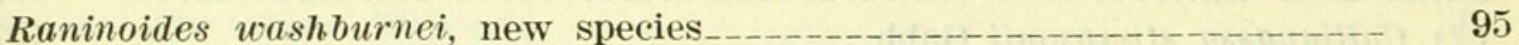

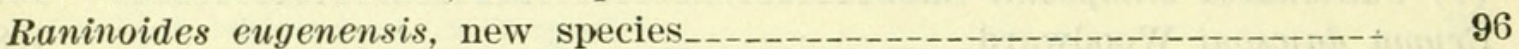

Raninoides fulgidus, new species______________ 96

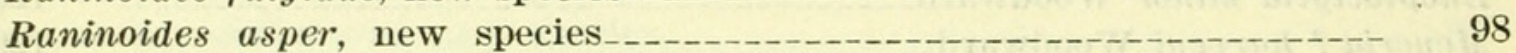

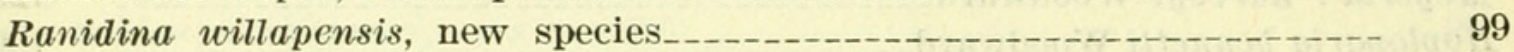

Eumorphocorystes naselensis, new species_____________ 100

Callianassa knapptonensis, new species__________ 112

Callianassa clallamensis Withers_______ 114

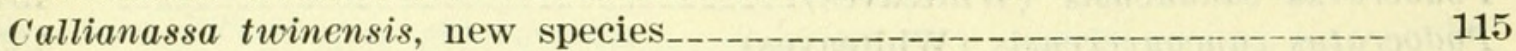

Callianassa bandonensis, new species____._._. 118

Callianassa porterensis, new species_______- 119

Callianassa oregonensis Dana_____________________ 121

Blepharipoda brucei, new species____ 126

MIOCENE

Branchiolambrus altus Rathbun

Paguristes, species, Rathbun 102

(?) Callianassa oregonensis Dana______________________________ 121

Astacus chenoderma Cope-__ 130

$\begin{array}{lll}P s e u d o s q u i l l a & \text { adelaidensis, new species________ } & 137\end{array}$

PLIOCENE

*Loxorhynchus grandis Stimpson

Uca oldroydi, new species___-__-_- 29

Uca hamlini, new species___-___- 30

Hemigrapsus, species, Rathbun

Cancer fissus Rathbun

Cancer urbanus Rathbun 61

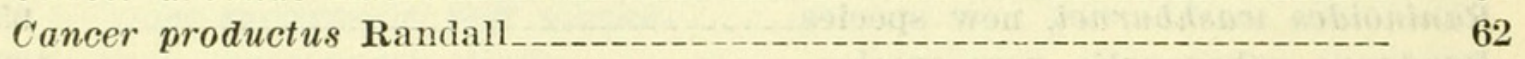

Callianassa kewana, new species______ 109

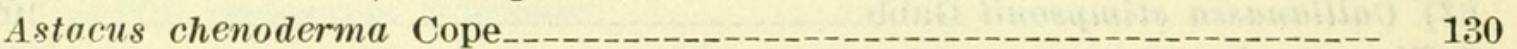

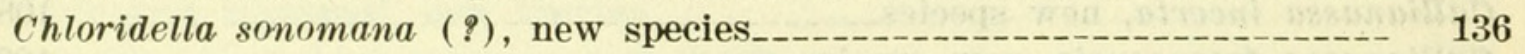

PLEISTOCENE

*Pyromaia tuberculata (Lockington) - 22

*Pugettia producta (Randall) 
*Pugettia richii Dana

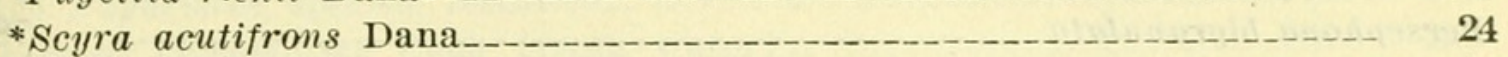

*Loxorhynchus grandis Stimpson

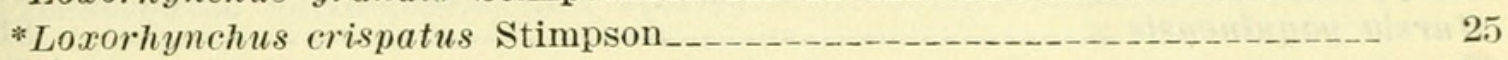

Chorilia, species, Rathbun

*Libinia setosa Lockington

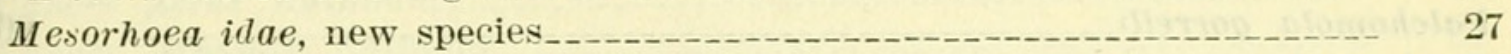

*Heterocrypta occidentalis (Dana)

*Hemigrapsus nudus (Dana)

*Hemigrapsus oregonensis (Dana)

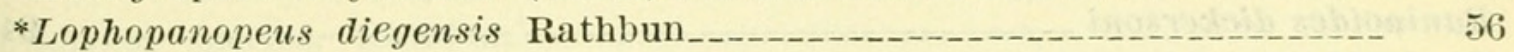

*Lophopanopeus leucomanus (Lockington) _-____- 56

*Lophopanopeus lockingtoni Rathbun

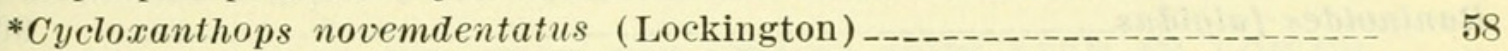

* Cancer productus Randall__________

* Cancer branneri, new species________- 63

* Cancer anthonyi Rathbun

* Cancer jordani Rathbun__.________- 64

*Cancer magister Dana

* Cancer gracilis Dana

*Portunus (Portunus) xantusii (Stimpson)

*Callinectes bellicosus (Stimpson)

*Randallia ornata (Randall)

Randallia pleistocenica, new species__________ 77

*Hepatus lineatus Rathbun___________ 84

Dardanus arnoldi, new species

*Pagurus granosimanus (Stimpson)

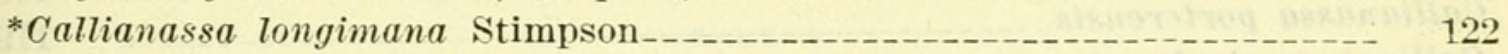

Callianassa stephensi, new species________ 122

NEW SPECIES

Mesorhoea idae

Uca oldroydi

Uca hamlini

Pinnixa eocenica

Playiolophus weaveri__._-__- 35

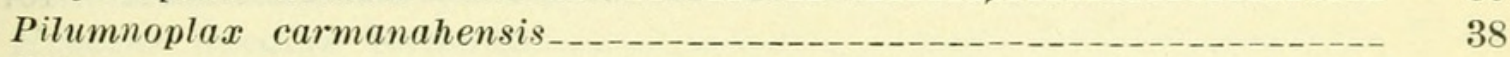

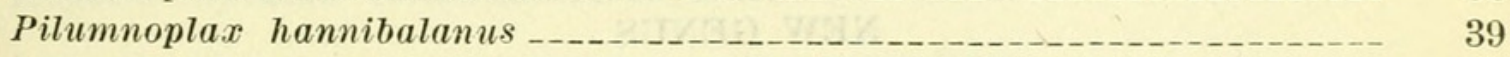

Pilumnoplax soledadensis _._- 41

Eucrate martini

Coeloma martinezensis _._.______

Zanthopsis vulgaris _._._. 48

Zanthopsis hendersonianus _._____ 53

Zanthopsis sternbergi

Lophopanopeus olearis _._. 57

Cancer gabbi

Cancer bainbridgensis________ 60

Cancer branneri________ 63

Carcinides minor

Portunites triangulum__________ 68

Portunites insculpta________

Portunites alaskensis____ 
Randallia pleistocenica

Persephona bigranulata

Calappa lanensis___ 79

Mursia yaquinensis _..._. 81

Mursia marcusana

Necrocarcinus hannae _..._. 84

Palehomola gorrelli

Ranina tejoniana________. 90

Raninoides vaderensis_____._. 93

Raninoides lewisanus_________ 94

Raninoides dickersoni

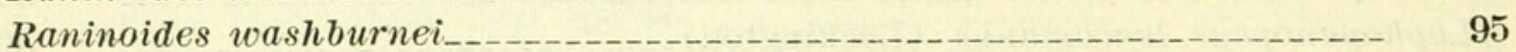

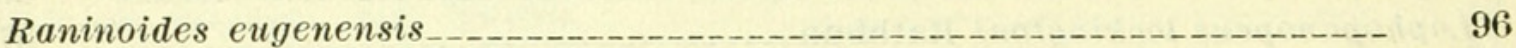

Raninoides fulgidus______._. 96

Raninoides asper._- 98

Ranidina willapensis _____ 99

Eumorphocorystes naselensis___________ 100

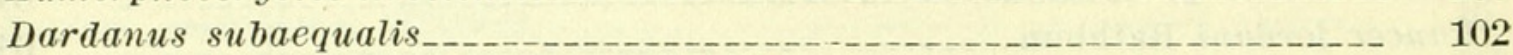

Dardanus arnoldi _._._._._. 103

Callianassa incerta____ 108

Callianassa kewana

Callianassa fresnoensis___________ 109

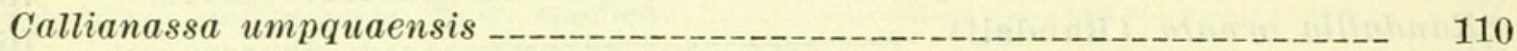

Callianassa knapptonensis ___ 112

Callianassa cowlitzensis_____________ 113

Callianassa twinensis_______ 115

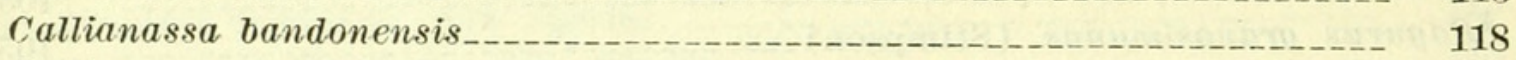

Callianassa porterensis_______ 119

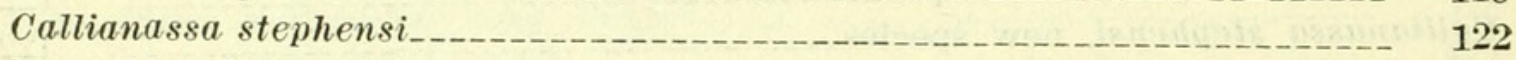

Upogebia (Upogebia) eocenica

Blepharipoda brucei

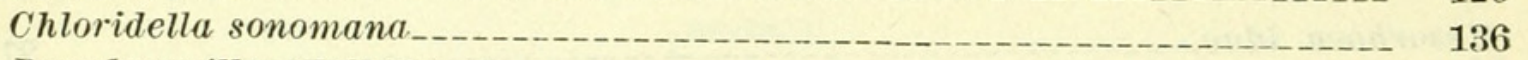

Pseudosquilla adelaidensis_____ 137

NEW NAME

Callianassa atlantica (Recent) 107

\section{NEW GENUS}

Palehomola

\section{SPECIES WHOSE NEAREST RELATIVES NOW LIVE IN SIMILAR LATITUDES}

EOCENE

Pinnixa eocenica, new species__________ 34

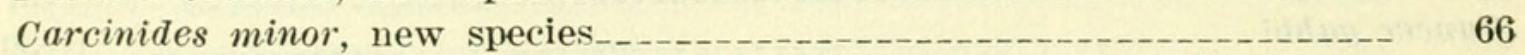

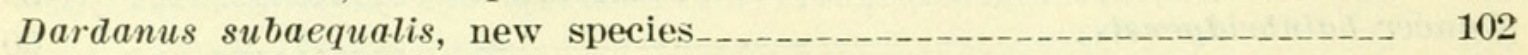

Upogebia (Upogebia) eocenica, new species____._. 124

OLIGOCENE

Eucrate martini, new species_..... 44

Lophopanopeus olearis, new species 
MIOCENE

(?) Paguristes, species, Rathbun

Astacus chenoderma Cope (fresh water)

130

Pseudosquilla adelaidensis, new species

PLIGCENE

Cancer fissus Rathbun

Cancer urbanus Rathbun

Astacus chenoderma Cope (fresh water)

PLEISTOCENH

Chorilia, species, Rathbun

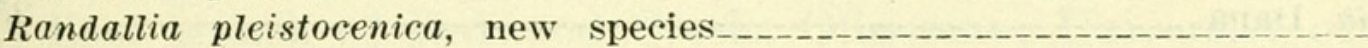

Callianassa stephensi, new species

\section{SPECIES WHOSE NEAREST RELATIVES NOW LIVE IN LOWER LATITUDES}

OLIGOCENE

Pilumnoplax carmanahensis, new species

Persephona bigramulata, new species

Calappa lanensis, new species____ 79

Mursia yaquinensis, new species___ 81

Mursia marcusana, new species._. 82

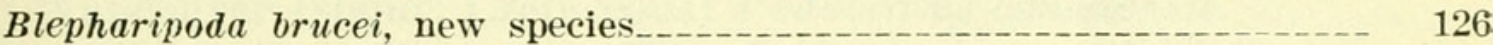

MIOCENE

Branchiolambius altus Rathbun

PLIOCENE

Uea oldroydi, new species

Uca hamlini, new species

Chloridella sonomana, new species

Libinia setosa Lockington

Mesorhoea idae, new species

Callinectes bellicosus (Stimpson)

Hepatus lineatus Rathbun

Archaeopus Rathbun

Plagiolophus Bell

Branchioplax Rathbun

Coeloma A. Milne Edwards

Zanthopsis M'Coy

Branchiolambius Rathbun

Portunites Bell _.- 68

Necrocarcinus Bell__ 84

Homolopsis Carter 86

Palehomola, new genus__________ 86

Graptocarcinus Roemer-___- 88

Eumorphocorystes von Binkhorst______ 100

Palaeocorystes Bell___._- 101 
Eryma von Meyer.

Enoploclytia M'Coy

Meyeria M'Coy

Hoploparia M'Coy

Glyphea von Meyer

Podocratus Becks

RECENT GENERA NOT BEFORE RECORDED AS FOSSIL

Pyrumaia Stimpson

Pugetia Dana

Scyra Dana_.

Chorilia Dana

Libinia Leach

Heterocrypta Stimpson

Pinnixa White

Pilumnoplax Stimpson

Eucrate de Haan.

Cycloxanthops Rathbun

Paguristes Dana

Dardanus Paulson

Blepharipoda Randall

Pseudosquilla Guérin 
I.OCALITIES IN GEOGRAPHICAL ORDER WITH THE SPECIES FOUND AT EACH

ALASKA

West end of Bering Lake; probably Oligocene; G. C. Martin, United States Geological Survey (2938); Branchioplax washingtoniana.

East branch of Redwood Creek; Oligocene; University of California (No. 3866); Portunites alaskensis.

Nichowak District, just below the lower seepage on Pearl Creek, on Pearl Creek oil claim No. 11; Oligocene; University of California (No. 3862); Lophopanopeus olearis; Portunites alaskensis.

BRITISH COLUMBIA

Skidegate Inlet, west of Alliford Bay, Queen Charlotte Islands; Cretaceous; Mus. Geol. Sur. Ottawa; Homolopsis richardsoni.

Vancouver Island; Cretaceous; Podocratus canadensis.

Comox River, Vancouver Island; Cretaceous; Plagiolophus vancouverensis; Palaeocorystes harveyi; Callianassa whiteavesii; Hoploparia bennetti.

Hornby Island; Cretaceous; Plagiolophus vancouverensis; Palaeocorystes harveyi; Eryma dawsoni; Enoploclytia minor; Meyeria? harveyi; Podocratus canadensis; Podocratus vancouverensis.

Two miles up Puntledge River, Vancouver Island; Nanaimo group, Cretaceous; Podocratus vancouverensis.

Nanaimo, Vancouver Island; Cretaceous; Glyphea, species.

Near Pachena Bay, Vancouver, near north point of entrance into Strait of Juan de Fuca; Oligocene, near boundary between Sooke and Carmanah formations; J. D. MeDonald, collector, 1905; Provincial Museum, Victoria; through F. Kermode and Dr. C. F. Newcombe; Zanthopsis vulgaris.

Sea cliffs $21 / 2$ miles south of Pachena Lighthouse, Vancouver Island; Oligocene; University of California (144); Zanthopsis vulgaris.

Basal sandstone sea cliffs between Clo-oose and Nitinat Lagoon, Vancouver Island; lower (?) Oligocene; Harold Hannibal, collector; Stanford University (N. Pac. 142); Zanthopsis vulgaris.

Sandstone shale sea cliffs for 3 miles west of Carmanah Point, Vancouver Island; Oligocene; H. Hannibal, collector; Stanford University (N. Pac. 141); Pilumnoplax carmanahensis; Zanthopsis vulgaris. 
Sandy shale sea cliffs at mouth of Five Mile Creek, Carmanah Point, Vancouver Island; Oligocene; Harold Hannibal, collector; Stanford University (N. Pac. 138); Zanthopsis vulgaris.

Sandy shale from sea cliff as found about 1 mile west of Seven Mile Creek, Carmanah Point, Vancouver Island; Oligocene; Harold Hannibal, collector; Stanford University (N. Pac. 137); Zanthopsis vulgaris.

Sea cliffs between Kow Shet Cove and Nine Mile Creek, Strait of Juan de Fuca, Vancouver Island; Oligocene; 1912; Harold Hannibal, collector; Stanford University (N. Pac. 136); Zanthopsis vulgaris.

WASHINGTON

In shale near station 214, Koitlah Point, 11/4 miles northwest of Neah Bay, Clallam County; Oligocene-Miocene; 1904; Ralph Arnold, United States Geological Survey (4135); Branchioplax washingtoniana.

Conglomerate sea cliffs at Koitlah Point west of Neah Bay; lower (?) Oligocene; H. Hannibal, collector; Stanford University (N. Pac. 167); Pilumnoplax hannibalanus; Branchioplax washingtoniana; Ranina americana.

Clallam Bay, south shore of Strait of Juan de Fuca; Blakeley formation, upper Oligocene; 1868; Robert Brown, collector; British Museum; Ranina americana.

Clallam Bay, south shore of Strait of Juan de. Fuca; Blakeley formation, upper Oligocene; British Museum; Callianassa clallamensis.

Twin, in shale sea cliffs west of West Twin River for a distance of three-fourths of a mile; upper (?) Oligocene; Stanford University (N. Pac. 120); Callianassa clallamensis; Callianassa twinensis.

About half a mile east of mouth of East Twin River, Clallam County; Oligocene; 1904; Ralph Arnold, United States Geological Survey; station 80, register No. 4091; Callianassa twinensis.

Sandy shales in sea cliffs 1 to 2 miles south of Eagle Creek, Port Discovery, Clallam County; Oligocene; Stanford University (N. Pac. 152); Zanthopsis vulgaris.

Sandy shale sea cliffs and beach, south shore of Mystery Inlet, Scow Bay, Port Townsend, Jefferson County; lower (?) Oligocene; Stanford University (N. Pac. 126); Zanthopsis vulgaris.

Port Townsend; Clallam formation, lower Oligocene; September 19, 1873, from Thomas T. Minor; loaned by Yale University Museum; Branchioplax washingtoniana.

Sea cliffs between Classens Wharf and the ship canal estuary, Townsend Bay; lower Oligocene; Stanford University (N. Pac. 125); Portunites alaskensis; Ranidina willapensis; Blepharipoda brucei. 
Sandstone and shale sea cliffs along west shore of Oak Bay, 1 to 2 miles south of Portage Spit between Port Townsend and Port Ludlow; lower (?) Oligocene; Stanford University (N. Pac. 128); Zanthopsis vulgaris; Portunites alaskensis.

South side of Rich's Passage, Puget Sound; basal conglomerate of upper Oligocene, or Blakeley formation; University of California (T. 42); Callianassa twinensis.

Restoration Point, Bainbridge Island, Kitsap County; upper Oligocene; University of Washington (Loc. 13); Callianassa porterensis.

Restoration Point, Bainbridge Island, Kitsap County; upper Oligocene; (Loc. T. 1, N. Pac. 103) University of Washington (164); Mursia marcusano.

Restoration Point, Bainbridge Island, Kitsap County; Blakeley formation, upper Oligocene; Marcus A. Hanna, collector; California Academy of Sciences; Mursia marcusana.

Sandstone beach at Bean Point, Bainbridge Island, Puget Sound; upper Oligocene; Stanford University (N. Pac. 205) ; Cancer bainbridgensis.

Shaly sandstone beach from Alki Point south one-fourth mile along shore of Puget Sound, Seattle; upper Oligocene; H. Hannibal, collector; Stanford University (N. Pac. 48); Mursia marcusana.

Northern Pacific Railway cut 100 feet east of Seattle Brewing and Malting Co.'s brewery at Georgetown, South Seattle, in section 20, township 24 north, range 4 east; Oligocene; University of Washington, No. 9 (old No. 3008); Zanthopsis vulgaris.

Burnett, Pierce County; labeled "Miocene"; probably Oligocene, Puget formation; 1898; H. J. Karstner, United States Geological Survey (3145); Zanthopsis vulgaris.

Vance's Creek, $21 / 2$ miles above junction with Skokomish River, 13 miles above Union; lower Oligocene; (N. Pac. 207) University of California; Portunites alaskensis.

Bed of Delezene Creek 5 or 6 miles up stream from its junction with Chehalis River, Chehalis County; Oligocene; California Academy of Sciences (194); Zanthopsis vulgaris.

Near Porter, Chehalis County, section 22, township 17 north, range 5 west; middle Oligocene; University of Washington; Zanthopsis vulgaris; Callianassa porterensis.

Porter, in bluff just below railroad station on Northern Pacific Railroad, section 22 , township 17 north, range 4 west; middle Oligocene; University of Washington (160); Zanthopsis vulgaris.

Shaly sandstone bluff on Chehalis River below Porter; middle Oligocene; Harold Hannibal, collector; Stanford University (N. Pac. 53); Zanthopsis vulgaris; Portunites triangulum; Callianassa porterensis. 
Porter; middle Oligocene; University of Washington; Zanthopsis vulgaris.

Porter; middle Oligocene; H. Landes, collector; Arnold Collection, Stanford University; Zanthopsis vulgaris; Portunites triangulum.

Porter, in bluffs immediately north and south of Porter; middle Oligocene; California Academy of Sciences (193); Zanthopsis vulgaris.

Porter Creek, near Porter; middle Oligocene; University of Washington; no number; Zanthopsis vulgaris.

Niarly tuffs along bluffs at old $\log$ dam along Porter Creek; lower Oligocene; associated with lowest fauna of Lincoln horizon, as defined by Dr. C. E. Weaver; Stanford University (N. Pac. 51) ; Zanthopsis vulgaris.

Shaly sandstone bluffs one-fourth mile below old log dam on Porter Creek, Porter; middle Oligocene; Harold Hannibal, collector; Stanford University (N. Pac. 52); Zanthopsis vulgaris.

Shaly sandstone bluffs along Porter Creek, one-fourth to 1 mile above old log dam, Porter; middle (?) Oligocene; Harold Hannibal, collector; Stanford University (N. Pac. 56); Zanthopsis vulgaris.

Shaly sandstone bluffs along Porter Creek, three-fourths of a mile above Porter; middle Oligocene; Harold Hannibal, collector; Stanford University (N. Pac. 54); Zanthopsis vulgaris.

Bluff one-half mile east of Porter Station, Chehalis County; Porter formation, middle Oligocene; Thomas Etherington, collector; University of Washington; Zanthopsis vulgaris; Portunites triangulum.

Shaly sandstone road cuts one-fourth mile southeast of Porter, along the Chehalis River; middle Oligocene; Harold Hannibal, coliector; Stanford University (N. Pac. 50); Zanthopsis vulgaris.

About five miles northwest of Oakville, Chehalis County, in shales on Gibson Creek; Oligocene; Katherine V. W. Palmer; Zanthopsis vulgaris.

Sandy blufis along Chehalis River for 1 mile east of HelsingJunction, Independence; upper Oligocene; N. Pac. 208; University of California; Callianassa oregonensis.

One and one half to two miles northwest of Galvin; middle Oligocene; Loc. T. 10, N. Pac. 300 ; Portunites triangulum.

Sandy shale bluffs along the Chehalis River northwest of the mouth of Lincoln Creek, Lincoln Creek (the creek runs into the river at Galvin); middle Oligocene; Harold Hannibal, collector; Stanford University (N. Pac. 211) ; Zanthopsis vulgaris; Portunites triangulum.

Near junction of Lincoln Creek and Chehalis River some 5 (?) miles northwest of Centralia, Lewis County; Lincoln beds, Oligocene; 1920; R. H. Palmer, collector; Portunites triangulum. 
Olequa Creek, one-fourth mile above Vader Station, Lewis County, in east bank, just north of where small creek enters Olequa on east; section 29, township 11 north, range 2 west; Eocene; University of Washington (237); Callianassa umpquaensis.

West bank of Olequa Creek about one-eighth mile north of Vader Station, Lewis County; section 29, township 11 north, range 2 west; Eocene; University of Washington, Loc. 324 (old No. 297); Pinnixa eocenica; Callianassa umpquaensis.

One mile west of junction of Olequa and Stillwater Creeks on the latter near Vader, Lewis County, in section 30, township 11 north, range 2 west; Tejon formation, upper Eocene; University of Washington, Loc. 6 (old No. 3005); Raninoides vaderensis.

One and a half miles east of Vader, Lewis County, in the bank of the Cowlitz River, just below the big bend; Cowlitz formation, upper Eocene; Marcus A. Hanna, collector; University of Washington; Branchioplax washingtoniana.

Railroad bluff about 11/2 miles south of Vader, Lewis County, about 700 feet below railroad post No. 79, section 4, township 11 north, range 2 west; upper Eocene; University of Washington, Loc. 331 (old No. 299) ; Carcinides minor; Raninoides lewisanus; Callianassa umpquaensis; Upogebia (Upogebia) eocenica.

Rock bluff in Northern Pacfiic Railway cut 2,850 feet south of milepost 76 and three-fourths of a mile north of Olequa Railway station; upper Eocene or Tejon; University of Washington (299); Callianassa umpquaensis.

Sandy shale bluffs along Cowlitz River, $1 \frac{1}{2}$ miles below mouth of Drew Creek, Olequa; Eocene; H. Hannibal, collector; Stanford University (N. Pac. 251); Pilumnoplax hannibalanus.

Southwestern part; at the type-locality of the Cowlitz formation, upper Eocene; September, 1922; E. E. and R. B. Stewart, collectors; University of California; Branchioplax washingtoniana.

On Coal Creek, Cowlitz County, about 21/4 miles up creek from Mount Solo; section 2, township 8 north, range 3 west; Eocene; University of Washington (341); Callianassa cowlitzensis.

Monterey sandstone bluffs along Wilson Creek 11/2 miles above Willapa, Pacific County; Oligocene (?); N. Pac. No. 245; Callianassa oregonensis.

Mill Creek, 11/2 miles east of junction with Willapa River, 3 miles northeast of Menlo, Pacific County; Oligocene; California Academy of Sciences (187); Zanthopsis vulgaris.

Tuffaceous sandstone bluffs along the Willapa River north of Holcomb, Pacific County; middle Oligocene; Harold Hannibal, collector; Stanford University (N. Pac. 253) ; Zanthopsis vulgaris; Portunites alaskensis; Ranidina willapensis. 
About 1 mile north and a little east of Holcomb, Pacific County, in east bank of Willapa River; Oligocene; California Academy of Sciences (188); Zanthopsis vulgaris.

One thousand six hundred feet above first railroad bridge on Willapa River below Holcomb; section 25, township 13 north, range 8 west; Oligocene; University of Washington; No. 80 (old No. 240); Zanthopsis vulgaris; Portunites alaskensis.

Shale bluffs along Nasel River near mouth of Salmon Creek, Nasel, Pacific County; middle Oligocene; Stanford University (N. Pac. 281; the number is badly rubbed but is almost certainly 281); Eumorphocorystes naselensis; Callianassa clallamensis.

In bluffs along the Nasel River, section $1,4 \frac{1}{2}$ miles east of Nasel; upper Oligocene; Blakeley horizon (Acila gettysburgensis zone of C. E. Weaver) ; Harold Hannibal, collector; Stanford University (N. Pac. 280); Zanthopsis vulgaris.

Sandstones in shales in bluffs along the Columbia River at Knappton Mill, Pacific County; upper Oligocene; Blakeley horizon (Acila gettysburgensis zone of C. E. Weaver); Stanford University (N. Pac. 275); Zanthopsis vulgaris.

North bank Columbia River three-fourths of a mile northeast of Knappton, Pacific County; Oligocene; California Academy of Sciences (175); Callianassa knapptonensis.

Cementville across river from Astoria, Oregon; Oligocene; Condon collection, University of Oregon (61); Zanthopsis vulgaris.

Cementville across river from Astoria, Oregon; Oligocene; Condon collection, University of Oregon (62); Zanthopsis vulgaris.

Cementville across river from Astoria, Oregon; Oligocene; University of Oregon (86); Zanthopsis vulgaris.

Sandy shale bluffs on Gray's River at Gray's River, Wahkiakum County; upper (?) Oligocene; Stanford University (N. Pac. 274); Callianassa twinensis.

OREGON

Near Astoria, Clatsop County; in calcareous concretions of argillaceous rock; "Miocene" [probably Oligocene]; United States Exploring Expedition; Callianassa oregonensis.

Astoria (?); Oligocene; Condon collection, University of Oregon (188); Zanthopsis vulgaris.

Nehalem River, ford north of Mishawaka, Clatsop County; Oligocene; 1895 ; J. S. Diller, United States Geological Survey; Portunites triangulum.

Basalt tuffs on the Tillamook branch, Southern Pacific Railway, 1 mile east of Wheeler, Nehalem Bay; middle (?) Oligocene; H. Hannibal, collector; Stanford University (N. Pac. 229); Pilumnoplax hannitalanus. 
Newport, Yaquina Bay, Lincoln County; Oligocene; 1901; Chester W. Washburne, United States Geological Survey (5423); Zanthopsis vulgaris.

Yaquina, Lincoln County; Oligocene; University of Oregon (509, 948); Zanthopsis vulgaris.

Yaquina, Lincoln County; Oligocene; Condon collection, University of Oregon $(70,883,884,885,886,888,946,947)$; Zanthopsis vulgaris.

Probably Yaquina; Oligocene; Condon collection, University of Oregon; no number (except one has 19); Zanthopsis vulgaris.

Probably near Yaquina; Oligocene; University of Oregon; Portunites trianguium.

Rocky Point, 4 miles east of Yaquina City in a railroad cut a few feet west of bridge No. 9; Oligocene; Bruce Martin, collector; California Academy of Sciences, Loc. 42 ; Eucrate martini; Zanthopsis vulgaris; Portunites triangulum; Mursia yaquinensis.

Sandy shale cut along the Corvallis and Eastern Railway, between Rocky Point and Oysterville, Yaquina Bay; Oligocene; Harold Hannibal, collector; Stanford University (N. Pac. 15); Zanthopsis vulgaris; Portunites triangulum; Callianassa porterensis.

Elk City, Lincoln County; Oligocene; University of Oregon (776); Zanthopsis vulgaris.

Near Pioneer Quarry near Elk City; Oligocene; Condon collection. University of Oregon $(774,775)$; Zanthopsis vulgaris.

West side of Judkins Ridge, Eugene, Lane County; Oligocene; Chester W. Washburne, collector, 387; United States Geological Survey (5454); Callianassa oregonensis.

Judkins Ridge, near Eugene; Oligocene series in sedimentary tufaceous sandstone; 1897 or 1898; Oscar Gorrell, collector and donor; Palehomola gorrelli.

Near Eugene; upper Oligocene; University of Oregon (No. 80); Portunites alaskensis; Raninoides washburnei; Raninoides eugenensis; Raninoides fulgidus; Callianassa oregonensis.

Springfield Junction, 1 mile west of Springfield, Lane County; Oligocene; 1897; Chester W. Washburne, United States Geological Survey (5458); Zanthopsis vulgaris; ?Graptocarcinus, species; Raninoides fulgidus; Raninoides asper; Callianassa oregonensis.

One fourth mile west of Springfield Junction on Southern Pacific Railroad, Lane County; Oligocene; 1897; Chester W. Washburne, United States Geological Survey (5456); Raninoides eugenensis; Raninoides fulgidus; Callianassa oregonensis.

One mile south of Springfield Junction, Lane County; Oligocene; 1905; Chester W. Washburne, United States Geological Survey (5457); Zanthopsis vulgaris. 
One mile south of Henderson Station (Springfield Junction), Southern Pacific Railroad, Lane County; Oligocene; Chester W. Washburne, collector; United States Geological Survey; Zanthopsis hendersonianus; Persephona bigranulata; Calappa lanensis.

Basket Point, Umpqua River, about 12 miles below mouth of Calapooia River, Douglas County; middle Eocene; 1898; Chester W. Washburne, United States Geological Survey (5455); Portunites insculpta; Raninoides vaderensis; Raninoides washburnei; Callianassa umpquaensis.

Shale sea cliffs south of mouth of Five Mile Creek, Bandon, Coos County; lower (?) Oligocene; Stanford University (N. Pac. 38); Callianassa bandonensis; Callianassa porterensis.

Near Eldorado, Malheur County; Pliocene; Charles W. McDowell, collector; Yale Museum; Astacus chenoderma.

Section 34, township 19 south, range 43 east, Snake River Valley, Malheur County; Payette formation, Miocene; Mr. Dunham, collector for Chester W. Washburne, United States Geological Survey; Astacus chenoderma.

Near Vale, Malheur County; Payette formation, Miocene; Chester W. Washburne, collector, United States Geological Survey; Astacus chenoderma.

IDAHO

Catharine's Creek (local name for upper part of Castle Creek), Owyhee County; Pliocene (?); J. C. Schenk, collector for Clarence King, in charge United States Geological exploration of fortieth parallel; Astacus chenoderma.

CALIFORNIA

Cottonwood Creek, Shasta County; Shasta Group, lower Cretaceous; W. M. Gabb, collector; Hoploparia (?), species.

Chico Creek; Chico Group; Upper Cretaceous; W. M. Gabb; ?Callianassa stimpsonii.

Five and a half miles southeast of Santa Rosa, three-tenths of a mile upstream from bridge crossing Matanzas Creek, on the left bank, four-tenths of a mile north of Grangers Hall, Sonoma County; Pliocene (?) ; August, 1923; R. Miller, collector; University of California, Loc. 7025; Hemigrapsus, species; Chloridella sonomana.

Santa Rosa Quadrangle, Sonoma County; 1 mile south of Mountain School and 11/2 miles southwest of Petaluma Reservoir, on right bank of creek bed; Miocene (?), fresh and brackish water zone; August, 1923; R. Miller, collector; University of California, Loc. 7027; Paguristes, species.

Martinez or Clayton, Contra Costa County; Eocene; W. M. Gabb, collector; Cancer gabbi; Callianassa stimpsonii; Callianassa incerta. 
About 4 miles south of Martinez and east of the road to Walnut Creek, Contra Costa County; upper beds, Martinez formation, Eocene; University of California, 542/11891; Plagiolophus weaveri.

West side of Tecuya Creek; southeast quarter of southeast quarter, section 26, township 10-20 west; Eocene series, very close to the type-locality of the Tejon formation; G. C. Gester, collector; presented by the Southern Pacific Railroad Co. to the California Academy of Sciences; Ranina tejoniana.

Canada de las Uvas; Eocene series (Cretaceous of Gabb); W. M. Gabb; ?Callianassa stimpsonii.

Bolsa Point, 1 mile north of Pigeon Point, San Mateo County; Loc. 27, Santa Cruz Quadrangle; Chico formation, upper Cretaceous; Ralph Arnold, United States Geological Survey; Archaeopus antennatus.

Canoas Creek, three-fourths of a mile below Hugo Kreyenhagen's ranch house, 16 miles southeast of Coalinga, Fresno County; Etchegoin formation, Pliocene; United States Geological Survey, Loc. 4783 ; Loxorhynchus grandis.

Near Henry Spring on east face of " 1900 foot hill" 4 miles south of Coalinga, Fresno County; toward base of Etchegoin formation, Pliocene; 1907; Ralph Arnold, United States Geological Survey, 4756; Cancer fissus.

Salt Creek, 31/4 miles north-northeast of Joaquin Rocks, Fresno County; south part of northwest quarter, section 15, township 18 south, range 14 east; Eocene; 1909; Robert Anderson, collector; United States Geological Survey (5665); Plagiolophus weaveri.

Salt Creek, 81/2 miles northwest of Oil City, Fresno County; Eocene; 1909; Robert Anderson, collector; United States Geological Survey (5682); Plagiolophus weaveri.

Southeast quarter of northwest quarter of section 15 , on branch of Salt Creek, township 18 south, range 14 east, Mount Diablo base line and meridian, Coalinga Quadrangle, Fresno County; near base of Tejon formation, middle Eocene; R. E. Dickerson, collector, 586; University of California, Loc. 1817; Plagiolophus weaveri; Raninoides dickersoni.

Salt Creek, southwest quarter, section 10; middle Eocene; August 30, 1909; R. W. Pack, United States Geological Survey (5675); ?Plagiolophus weaveri.

One mile southeast of Oil City, Fresno County; Eocene (Tejon of Arnold); G. Dallas Hanna, collector; California Academy of Sciences, Loc. 874; Necrocarcinus hannae; Callianassa fresnoensis.

Two and a half miles south of mouth of Soledad, Valley in the sea cliff; Eocene; Marcus A. Hanna and Georges Vorbe, collectors; University of California, No. 5062; Pilumnoplax soledadensis; Carcinides minor (?). 
South central part of southeast quarter of section 24, Coalinga Quadrangle; Etchegoin formation, Pliocene; University of California, No. 2371; Cancer fissus.

Adelaide Quadrangle, central part about 6 miles west of Templeton, San Luis Obispo County; Monterey shales, middle Miocene; Dr. M. G. Edwards of the Shell Oil Co., collector; University of California; Pseudosquilla adelaidensis.

Wagon Wheel Mountain, southeast quarter, section 36, township 25 south, range 18 east, Devils Den district, about 36 miles south of Coalinga, Kern County; lower Miocene immediately below Vaqueros beds; 1907; Ralph Arnold, collector; United States Geological Survey, No. 4859 ; Branchiolambrus altus.

Near Santa Barbara; Pliocene; Cancer productus (=Cancer brewerii).

Llajas Canyon, Simi Valley, Ventura County; Santa Susana shales, the basal member of the Meganos group, Middle Eocene; September, 1923; R. P. Stewart, collector; University of California, Loc. 7014; Zanthopsis hendersonianus; Callianassa cowlitzensis.

Ventura County; Pliocene; Louis N. Waterfall; Cancer productus. Rock Creek Quadrangle, Los Angeles County; Martinez formation, Eocene; L. F. Noble, Loc. 5 ; United States Geological Survey; Coeloma martinezensis.

Third Street Tunnel, Los Angeles; Pliocene; January 22, 1901; Homer Hamlin, collector, No. 40; United States Geological Survey, No. 3426; Uca hamlini.

Los Angeles, from foundation of large building; Pliocene; 1914; J. Z. Gilbert, collector; Cancer urbanus.

Long wharf, Santa Monica; Pleistocene; F. C. Clark, collector; Loxorhynchus crispatus; Randallia ornata.

Rincon del Potrero, Santa Monica; Pleistocene; F. C. Clark, collector; Pugettia producta; Loxorhynchus grandis; Libinia setosa; Heterocrypta occidentalis; Lophopanopeus diegensis; Cycloxanthops novemdentatus; Cancer productus; Cancer jordani; Cancer gracilis; Randallia ornata; Dardanus arnoldi; Callianassa longimana.

Santa Monica, in Rustic Canyon; Pliocene; D. F. Clark, collector; Cancer urbanus.

Nob Hill (lumber yard), northeast of San Pedro; lower San Pedro formation, Pleistocene; T. S. Oldroyd collector; Pugettia producta; Pugettia richii; Mesorhoea idae; Hemigrapsus nudus; Hemigrapsus oregonensis; Lophopanopeus diegensis; Lophopanopeus leucomanus; Lophopanopeus lockingtoni; Cancer productus; Cancer jordani; Cancer magister; Cancer gracilis; Randallia ornata; Randallia pleistocenica; Pagurus granosimanus; Callianassa stephensi. 
San Pedro; Pleistocene; Kate Stephens, collector; Pugettia richii; Hemigrapsus oregonensis; Lophopanopeus diegensis; Lophopanopeus leucomanus; Cancer productus; Cancer branneri; Cancer jordani; Randallia pleistocenica.

Deadman Island, southeast of San Pedro; Pleistocene: Arnold collection, Stanford University; Pyromaia tuberculata; Pugettia producta; Pugettia richii; Scyra acutifrons; Loxorhynchus crispatus; Choritia, species; Mesorhoea idae; Hemigrapsus nudus; Hemigrapsus oregonensis; Lophopanopeus diegensis; Lophopanopeus leucomanus; Cancer productus; Cancer branneri; Cancer jordani; Cancer gracilis; Randallia ornata; Randallia pleistocenica; Dardanus arnoldi; Pagurus granosimanus; Callianassa longimana.

Deadman Island, southeast of San Pedro; Pliocene; Stanford University; Uca oldroydi.

Signal Hill (or Los Cerritos), northeast of Long Beach; Upper San Pedro formation, Pleistocene; Ida S. Oldroyd, collector; Pyromaia tuberculata; Pugettia richii; Mesorhoea idae; Hemigrapsus nudus; Lophopanopeus diegensis; Lophopanopeus leucomanus; Cancer productus; Cancer branneri; Callinectes bellicosus; Randallia ornata; Hepatus lineatus; Callianassa stephensi.

Carrizo Creek, Imperial County; Eocene; W. S. W. Kew, collector, Loc. 55; University of California; Callianassa kewana.

Kelly's Ranch, 5 miles north of Carlsbad Station, on Santa Fe Railway, San Diego County; Cretaceous; Charles H. Sternberg, collector; Zanthopsis sternbergi.

Two miles east of La Jolla, in bottom of Rose Creek where the creek makes a strong bend to the west; just west of the brick plant. On the La Jolla topographic sheet, two-tenths of a mile south of B. M. 176; middle Eocene; Marcus A. Hanna and Georges Vorbe, collectors, Loc. 3993; University of California; Plagiolophus weaveri.

Vicinity of La Jolla (exact locality not supplied); Eocene; University of California, 5084 [or 5024]; received through Marcus A. Hanna; Dardanus subaequatis.

Point Loma, "coal mine," ocean shore of Point; April 5, 1918; Pleistocene; Frank Stephens, collector; Cancer productus.

Spanish Bight, San Diego Bay; Pleistocene; Kate Stephens, collector; Pyromaia tuberculata; Pugettia richii; Hemigrapsus nudus; Cancer anthonyi; Cancer jordani; Cancer gracilis; Randallia ornata; Hepatus lineatus; Callianassa longimana.

Spanish Bight, San Diego Bay; Pleistocene; San Diego Society of Natural History; Pyromaia tuberculata; Libinia setosa; Cancer gracilis; Portunus (Portunus) xantusii; Randallia ornata; Callianassa stephensi. 
Locality not given; Eocene; University of California (572); Plagiolophus weaveri.

MEXICO

San Quentin Bay, Lower California, lava beds; Pleistocene; C. R. Orcutt; Cancer productus.

SYSTEMATIC LIST

Order DECAPODA Latreille Suborder REPTANTIA Boas

Tribe BRACHYURA Latreille

Subtribe BRAChygnatha Borradaile

Superfamily OXYRHYNCHA Dana

Family MAJIDAE Rathbun (MAIIDAE Alcock)

SPIDER CRABS

Chelipeds especially mobile, rarely much greater than the other legs, or with fingers bent at an angle on the hand. Second article of antennae well developed, generally fused with epistome and often with front. Orbits usually more or less incomplete. Hooked hairs almost always present. Palp of external maxillipeds articulated either at summit or at antero-internal angle of merus.

\section{Genus PYROMAIA Stimpson}

Pyromaia Stimpson, Bull. Mus. Comp. Zoöl., vol. 2, 1871, p. 109; type, P. cuspidata Stimpson.-RAthbun, Buil. U. S. Nat. Mus., No. 129, 1925, p. 127.

Carapace pyriform, rough; rostrum simple. Postorbital spine large, distant from orbit, tip directed forward. Palm swollen; fingers long, curving inward. Abdomen of female very convex, unevenly tuberculate.

Pleistocene; Recent. Not before found fossil.

\section{PYROMAIA TUBERCULATA (Lockington)}

Plate 1, fig. 1

Inachus tuberculatus Lockington, Proc. California Acad. Sci., vol. 7, 1876 (1877), p. 30 [3].

Inachoides tuberculatus Schмгтт, Univ. California Publ. Zool., vol. 23, 1921, p. 199, text-fig. 123.

Pyromaia tuberculata Rathbun, Bull. U. S. Nat. Mus., No. 129, 1925, p. 133, pl. 40, fig. 3 , pl. 218, figs. 1-4, and synonymy. 
Occurrence.-California; Pleistocene series.

Deadman Island, southeast of San Pedro; one right immovable finger.

Signal Hill (or Los Cerritos), northeast of Long Beach; Upper San Pedro formation; a piece of merus of an ambulatory leg; Cat. No. 353595 , U.S.N.M.

Spanish Bight, San Diego Bay: One left movable and immovable finger, three female abdomens (pl. 1, fig. 1), and several fragments of $\operatorname{legs}_{\text {; }}$ Cat. No. 353356, U.S.N.M. One left manus with fixed finger attached, and one female abdomen; Cat. No. 353357, U.S.N.M.

Range of Recent specimens.-From Monterey Bay to Bay of Panama.

\section{Genus PUGETTIA Dana}

Pugettia Dana, Amer. Journ. Sci., ser. 2, vol. 11, 1851, pp. 268 and 433 ; type, P. gracilis Dana.-Rathbun, Bull. U. S. Nat. Mus., No. 129, 1925, p. 167 .

Carapace suboblong, with two wings on each side. Supra-orbital eave well developed, forming a preocular tooth. Rostrum bifid. Palm dilated and compressed, fingers usually gaping at base, dentate toward extremity, a larger tooth on dactyl in gape.

Pleistocene; Recent. Not before found fossil.

\section{PUGETTIA PRODUCTA (Randall)}

Epialtus productus RANdall, Journ. Acad. Nat. Sci. Philadelphia, vol. 8, 1839 (1840), p. 110.

Pugettia producta Rathbun, Bull. U. S. Nat. Mus., No. 129, 1925, p. 167, pls. 56 and 57.

Occurrence.-California; Pleistocene series:

Rincon del Potrero, Santa Monica; piece of dactylus of a right ambulatory leg; Cat. No. 353354, U.S.N.M.

Nob Hill (lumber yard), northeast of San Pedro; lower San Pedro formation; two movable fingers; Cat. No. 353375, U.S.N.M.

Deadman Island, southeast of San Pedro; one right immovable finger.

Range of Recent specimens.-From Vancouver Island, British Columbia, to Santa Rosalia Bay, Lower California.

\section{PUGETTIA RICHII Dana}

Pugettia richii Dana, Amer. Journ. Sci., ser. 2, vol, 11, 1851, p. 268.Rathbun, Bull. U. S. Nat. Mus., No. 129, 1925, p. 176, text-fig. 66.

Occurrence.-California; Pleistocene series:

Nob Hill (lumber yard), northeast of San Pedro; lower San Pedro formation; one right and one left immovable finger; Cat. No. 353374 , U.S.N.M. 
San Pedro; one dactyl of left cheliped; Cat. No. 353355, U.S.N.M. Deadman Island, southeast of San Pedro; one movable finger.

Signal Hill (or Los Cerritos), northeast of Long Beach; Upper San Pedro formation; piece of merus of ambulatory leg.

Spanish Bight, San Diego Bay; end of propodal finger of left cheliped.

Range of Recent specimens.-From Vancouver Island to San Diego Bay.

\section{Genus SCYRA Dana}

Scyra Dana, Amer. Journ. Sci., ser. 2, vol. 11, 1851, p. 269 ; type, S. acutifrons Dana.-RAthBUn, Bull. U. S. Nat. Mus., No. 129, 1925, p. 195.

Carapace subpyriform, with few or no spines; rostral horns flattened, sharp-pointed. Orbits small, a fissure above and below, preorbital spine present. Hand compressed, carinated above; fingers with sharp, crenulated prehensile edge.

Pleistocene; Recent. Not before found fossil.

\section{SCYRA ACUTIFRONS Dana}

Scyra acutifrons DANA, Amer. Journ. Sci., ser. 2, vol. 11, 1851, p. 269.Rathbun, Bull. U. S. Nat. Mus., No. 129, 1925, p. 195, pls. 79 and 224, figs. 4 and 5 .

Occurrence.-California; Deadman Island, southeast of San Pedro; Pleistocene series; three movable fingers and a right manus with fixed finger attached.

Range of Recent specimens.-From Kodiak to San Diego.

\section{Genus LOXORHYNCHUS Stimpson}

Loxorhynchus Strmpson, Journ. Boston Soc. Nat. Hist., vol. 6, 1857, p. 451 [10] ; type, L. grandis Stimpson.-Rathiun, Bull. U. S. Nat. Mus., No. 129, 1925, p. 198.

Of large size. Carapace pyriform, rough and hairy; rostrum bifid, deflexed. Orbits imperfect, preorbital tooth strong, postorbital acute. Basal antennal article broad. Chelipeds of male much enlarged, extremities dentate or crenate, dactylus flat-topped at base and with a large basal tooth in gape.

Pliocene-Recent.

\section{LOXORHYNCHUS GRANDIS Stimpson}

Plates 2 and 3 ; plate 4 , fig. 1

Loxorynchus grandis Stimpson, Proc. Boston Soc. Nat. Hist., vol. 6, 1857, p. 85 .

Loxorhynchus grandis Stimpson, Journ. Boston Soc. Nat. Hist., vol. 6, 1857, p. 452 , pl. 20, fig. 1 ; pl. 22, fig. 1.-Rathbun, Proc. U. S. Nat. Mus., vol. 35,1908 , p. 342 , pls. $45,46,47$, fig. 1 ; Bull. U. S. Nat. Mus., No. 129 , 1925 , p. 198 , text-fig. 80 , pls. 64 and 65 . 


\section{Occurrence.-California :}

Canoas Creek, three-fourths of a mile below Hugo Kreyenhagen's ranch house, 16 miles southeast of Coalinga, Fresno County; in a rather hard, coarse blue-gray sandstone layer about 125 feet stratigraphically below the top of the Etchegoin formation, Pliocene series; one adult female, Cat. No. 165476, U.S.N.M. (pls. 2 and 3; pl. 4, fig. 1).

Rincon del Potrero, Santa Monica, Los Angeles County; Pleistocene series; 60 fragments of fingers; Cat. No. 353369, U.S.N.M. One of the fragments, the basal portion of a movable finger, belongs to a larger specimen than any Recent individual recorded. The greatest width of the upper surface of the dactyl, close to the condyles which articulate with the propodus, is $22.2 \mathrm{~mm}$. The corresponding width in the largest Recent specimen in the United States National Museum is $17 \mathrm{~mm}$., the carapace having a length of $20 \mathrm{~cm}$. Range of Recent specimens.-From San Francisco, California, to San Martin Island, Lower California; to a depth of 68 fathoms.

\section{LOXORHYNCHUS CRISPATUS Stimpson}

Loxorhynchus crispatus Stimpson, Journ. Boston Soc. Nat. Hist., vol. 6, 1857, p. 453, pl. 22, figs. 2-4.-Rathbun, Bull. U. S. Nat. Mus., No. 129,1925 , p. 200 , pls. 66 and 67.

Occurrence.-California; Pleistocene series:

Long wharf, Santa Monica; one immovable finger of young specimen.

Deadman Island, southeast of San Pedro; one rostrum with adjacent part of carapace, two movable, and one immovable, finger, all from young specimens.

Range of Recent specimens.-From San Francisco to San Diego.

\section{Genus CHORILIA Dana}

Chorilia Dana, Amer. Journ. Sci., ser. 2, vol. 11, 1851, p. 269; type, $C$. longipes Dana.-Rathbun, Bull. U. S. Nat. Mus., No. 129, 1925, p. 202.

Carapace subpyriform, convex. Rostral spines long, slender. divergent. A preocular spine; supraocular hood separated by a $U$-shaped sinus from postocular cup. Palm compressed, upper margin acute; fingers denticulate, gaping in basal portion.

Pleistocene; Recent. Not before found fossil.

\section{CHORILIA, species}

Plate 1, fig. 2

A small finger only $6.2 \mathrm{~mm}$. long, having the appearance of an adult male. It resembles the dactylus of $C$. longipes Dana, ${ }^{2}$ with one

2 Amer. Journ. Sci., ser. 2, vol. 11, 1851, p. 269. Rathbun, Bull. U. S. Nat. Mus., No. 329,1925 , p. 203 , pl. 224 , figs. $1-3$; pl. 225 ; text-figs. 81 and 82 .

$3020-26-3$ 
groove on either side, the outer groove wider than the inner, surface coarsely punctate, a large tooth in the gape; on the other hand, the grooves are deeper than in longipes, the finger shorter in proportion to its basal width and slightly more curved; moreover, the dentation of the distal half is not true to type. It consists of five teeth, diminishing in size, the proximal one being larger than the subbasal tooth, the space between the two having at its middle a small tooth or tubercle; in longipes the distal teeth are seven or eight in number, are more closely placed and similar in shape and size, becoming smaller gradually toward tip of finger.

Occurrence.-Deadman Island, southeast of San Pedro; Pleistocene series; one right movable finger.

\section{Genus LIBINIA Leach}

Libinia LeAch, Zool. Misc., vol. 2, 1815, p. 129 ; type, L. emarginata Leach, Recent.-Rathbun, Bull. U. S. Nat. Mus., No. 129, 1925, p. 310.

Carapace rotund, tuberculate or spinous, with a small, emarginate rostrum. Orbits small, subcircular, upper fissure closed or nearly so. Palm elongate, fingers usually evenly denticulate on prehensile edges. Miocene; Pleistocene; Recent.

\section{LIBINIA SETOSA Lockington}

Libinia setosa Lockington, Proc. California Acad. Sci., vol. 7, 1876 (1877), p. 68 [6].-Rathbun, Bull. U. S. Nat. Mus., No. 129, 1925, p. 327, pl. 243.

Occurrence.-California; Pleistocene:

Rincon del Potrero, Santa Monica; one large movable finger; Cat. No. 353364, U.S.N.M.

Spanish Bight, San Diego Bay; one large movable finger.

Range of Recent specimens.-Known only from the west coast of Lower California.

\section{Family PARTHENOPIDAE Alcock}

Chelipeds not especially mobile, usually much longer and heavier than the other legs and with fingers bent on hand at an angle toward the side on which the fixed finger is set. Second article of antennae small, short, not fused with epistome or front. Orbits well made. Hooked hairs almost always wanting. Palp of external maxillipeds articulated at antero-internal angle of merus.

\section{Genus MESORHOEA Stimpson}

Mesorhoea Stimpson, Bull. Mus. Comp. Zoöl., vol. 2, 1871, p. 135; type, M. sexpinosa Stimpson.-Rathbun, Bull. U. S. Nat. Mus., No. 129, 1925 , p. 546.

Carapace pentagonal, smooth, convex, bearing four large spines, on the gastric, cardiac and branchial (paired) regions. Efferent 
branchial channels meeting at middle of endostome, as in the Oxystomes. Arm and hand elongate, triangular in cross-section, edges dentate; fingers very short.

Miocene; Pleistocene; Recent.

\section{MESORHOEA IDAE, ${ }^{3}$ new species}

Plate 1, figs. 5-10

Mesorhoea, new species, T. S. Ordnoyd, Proc. U. S. Nat. Mus., vol. 65, art. 22, 1924, p. 23.

Description.-Propodus of cheliped: Inner surface of palm (pl. 1, fig. 8) widening from proximal to distal end, upper outer surface (pl. 1, fig. 9) widest at middle, narrowing to either end, lower surface (pl. 1, fig. 10) narrowest in middle, widening to either end. Teeth of upper margin 14, of which three have a small subsidiary tooth on the proximal slope; teeth of outer margin 17, alternating in size; of inner margin 14 followed by two tubercles on the digit. Teeth acute or subacute, in profile channeled by deep furrows except toward the tips; viewed from above the teeth are seen to be thick, and each is crossed transversely over its summit by a row of six or fewer shiny granules. On the lower outer surface near the carpus there is a longitudinal row of three granules (pl. 1, fig. 10); also a row of granules on each of the condyles articulating with the carpus. The propodal finger is bent obliquely inward, is quadrangular in cross-section, prehensile edge armed with six tubercles, the first three, nearest the palm, very small, the next two large, the last one, near the tip, of medium size. The outer angles of the finger are also tuberculate, the line of tubercles continued well upward on the manus either side of the dactylus.

Merus of cheliped: Upper surface a little narrower in the middle than toward the ends (pl. 1, fig. 6) ; outer surface curved (concave upwards) of subequal width throughout (pl. 1, fig. 7), inner surface narrow at proximal end, widening distally (pl. 1, fig. 5). Inner margin with 17 teeth alternating large and small, outer margin with 18 smaller teeth also alternating; lower margin with 16 teeth mostly alternating in size. The third large tooth from the proximal end of the inner margin is more prominent than the others. The teeth are granulated in a similar manner to those of the manus but in a top view the teeth are narrower than on the manus and the granulation less evident. A tubercle or large granule is on the inner surface. near the lower margin in the proximal third (pl. 1, fig. 5); in another specimen (Nob Hill) the tubercle is on the upper surface not far behind the middle.

${ }^{3}$ For Mrs. Ida S. Oldroyd, conchologist of Stanford University. 
Measurements.-Holotype, length of upper margin of manus $17 \mathrm{~mm}$., length of outer margin of manus (articulating condyle broken) $16.8 \mathrm{~mm}$., length of inner margin measured to tip of finger $19.3 \mathrm{~mm}$., greatest width of outer surface $4.8 \mathrm{~mm}$. Right merus, Deadman Island, paratype, length on inner margin $11 \mathrm{~mm}$.

Occurrence.-California; Pleistocene series:

Nob Hill (lumber yard), northeast of San Pedro; lower San Pedro formation; one left manus (Stanford University), one left manus, one fragment of manus, one right merus (U.S.N.M., Cat. No. $353379)$; paratypes.

Deadman Island southeast of San Pedro; one right merus, one piece of a left manus; paratypes.

Signal Hill (or Los Cerritos), northeast of Long Beach; upper San Pedro formation, Pleistocene series; one propodus of left cheliped, holotype, in Stanford University.

Relation.-These arms and hands are very near M. bellii (A. Milne Edwards), ${ }^{4}$ a Recent species inhabiting both coasts of Lower California and also the Bay of Panama in depths varying from $91 / 2$ to 71 fathoms. In bellii, however, the articles are slenderer, their marginal teeth fewer and thinner, and finely granulate on all sides instead of in a transverse line.

\section{Genus HETEROCRYPTA Stimpsen}

Heterocrypta Stimpson, Ann. Lye. Nat. Hist. New York, vol. 10, 1871, p. 102 [129]; type, H. granulata (Gibbes).-RathвUn, Bull. U. S. Nat. Mus., No. 129, 1925 , p. 554 .

Carapace broad, pentagonal, expanded so as to partially cover legs and abdomen. A branchial ridge subparallel to antero-lateral margin extends to gastric region. Palm very long, fingers short, triangular in cross-section.

Pleistocene; Récent. Not before found fossil.

HETEROCRYPTA OCCIDENTALIS (Dana)

Cryptopodia occidentalis DANA, Amer. Journ. Sci., ser. 2, vol. 18, 1854, p. 430, woodeut.

Heterocrypta occidentalis Rathbun, Bull. U. S. Nat. Mus., No. 129, 1925, p. 559, pls. 204 and 205, and synonymy.

Occurrence.-California : Rincon del Potrero, Santa Monica; Pleistocene series; nine right movable, one immovable finger; U. S. N. M., Cat. No. 353363. Specimens much worn. Outer edge of superior triangular surface in most cases indistinct.

Range of Recent specimens.-From the Farallones, California, to Los Coronados Islands, Mexico.

${ }^{4}$ Solenolambrus bellii A. Milne Edwards, Crust. Rég. Mex., 1878, p. 163, pl. 29, figs. 6-6d. 


\title{
Superfamily BRACHYRHYNCHA Borradaile
}

\section{Family OCYPODIDAE Milne Edwards}

Front not wide and often a narrow deflexed lobe; the orbits occupy the whole anterior border of the carapace outside the front, their outer wall often defective. Buccal cavern large, a little narrower in front, the outer maxillipeds often completely closing it; palp coarse, articulating at or near antero-external angle of merus. Abdomen of male narrow. Male openings sternal.

\section{Genus UCA Leach}

\author{
FIDDLER CRABS
}

Uca LEACH, Edin. Encyc., vol. 7, 1814, p. 430 ; type, U. una Leach, 1814 $=U$. heterochelos (Lamarck), 1801.-Rathbun, Bull. U. S. Nat. Mus., No. 97,1918 , p. 374 .

Carapace subquadrilateral, antero-lateral angles produced; front narrow, orbits occupying remainder of width of carapace. Chelipeds of male extraordinarily unequal, of female small and equal.

Pliocene-Recent.

\section{UCA OLDROYDI, 5 new species}

Plate 7, figs. 1 and 2

Description.-The anterior margin of the carapace either side of the rostrum is oblique and sinuous; next to the rostrum it forms a deep narrow bay, followed by a long arch the inner slope of which is short and the outer long (pl. 7, fig. 1); outer angle acute, directed outward and forward; situated in a line considerably behind the rostrum. Rostrum small, spatulate, neck of spatula nearly as broad as blade, the median furrow linear, continued backward in a broad shallow depression. Lateral depressions irregular, but in the main parallel to the median line. Dorsal surface, so far as it remains, nongranulate. Lateral margins concave, moderately convergent posteriorly, and marked by a faintly granulate blunt rim.

The specimen has been strongly compressed dorsally and the lower margin of the orbit pushed forward; only one tubercle remains on it and that is long, large and truncate. The ambulatory legs down to the ends of the merus are partly visible; the merus has a strongly convex upper margin, a slightly convex lower margin. The abdominal segments have been so disturbed that the proportions of only the fifth can be determined (pl. 7, fig. 2).

Measurements (approximate).-Holotype male, length of carapace $18.5 \mathrm{~mm}$., width of same $29.3 \mathrm{~mm}$.

${ }^{5}$ Named for Mr, and Mrs. T. S. Oldroyd, who have collected, and been instrumental in sending, large numbers of California fossils for inclusion in this report. 
Occurrence.-California: Deadman Island, near San Pedro, Los Angeles County; Pliocene series; one specimen, male, without chelipeds, holotype, in Stanford University.

Relation.-This species is, so far as can be seen without a knowledge of the chelipeds, most nearly related to the Recent $U$. monilifera ${ }^{6}$ of the Gulf of California; they both have an uneven carapace, a sinuous anterior, or supraorbital, margin and a coarsely turreted infraorbital margin; $U$. monilifera has a more transverse anterior margin, a broader blade and more constricted neck to the rostrum, a smoother lateral margin, and less inflated meropodites.

\section{UCA HAMLINI, new species}

Plate 8, fig. 1

Description.-Upper and lower margins of palm subparallel except toward the carpus, a portion of which is to be seen adjacent to upper half of manus (pl. 8, fig. 1); distal end of manus oblique. Fingers broad, meeting at base, gradually diminishing to the extremities, dactylus arched so as to form a wide gape between the fingers when flexed. Very little of the outer layer of shell remains. The manus is swollen at the articulation with the dactylus. The lower margin of propodus, including the finger, has a narrow raised rim; above the rim a row of fine punctae. There is a blunt, obliquely longitudinal ridge on base of finger, perhaps accidental. The finger curves slightly upward toward the end; at the middle of the prehensile edge a broad, triangular, blunt-pointed tooth, with a long, gradual proximal slope, and a short distal margin normal to the finger. The dactylus tapers to a slender, blunt tip, its prehensile edge is crenulate near the tip, at the proximal end it forms a broad shallow crenated lobe with six thick crenae.

Measurements.-Holotype, length of chela through middle of palm to end of dactylus $38.3 \mathrm{~mm}$., to end of propodal finger $36 \mathrm{~mm}$., length of manus on upper margin $12.8 \mathrm{~mm}$., through the middle 18 $\mathrm{mm}$., greatest width of manus near proximal end $17 \mathrm{~mm}$., length of dactylus measured from upper point of union with palm $24 \mathrm{~mm}$. The palm has an oblique fracture across the middle which may have shortened the true length of the article.

Occurrence.-California: Third Street tunnel, Los Angeles; Pliocene series; one right chela of a male, holotype (Cat. No. 353372, U.S.N.M.).

Relation.-In the comparative length of palm and fingers, this species is related to several Recent short-fingered species of the Pacific coast of America, such as $U$. macrodactylus ${ }^{7}$ (Mexico to

\footnotetext{
${ }^{6}$ Rathbun, Bull. U. S. Nat. Mus., No. 97, 1918, p. 380, pl. 132.

${ }^{7}$ Gelasimus macrodactylus Milne Edwards and Lucas, in d'Orbigny's Voy. dans. l'Amér. Mérid., vol. 6, 1843, Crust., p. 27 ; vol. 9, atlas, 1847, pl. 11, fig. 3.
} 
Chile) and $U$. helleri ${ }^{8}$ (Galapagos Islands). Both of these have a tooth at the middle of the fixed finger and coarse tubercles at the proximal end of the prehensile margin of the dactylus. The coarse tubercles are distinctly separated, not crowded together like the crenae of the fossil, nor are the tubercles arranged on a projecting lobe but along the middle of the broad prehensile margin. Neither of the Recent species mentioned has the lower margin of the fixed finger rimmed.

I hesitate to associate the claw here described with the narrowfronted $U c a$ oldroydi. The latter is related to $U$. monilifera and probably has a cheliped similar to that of monilifera and other narrow-fronted species of the American coasts, with an extremely broad, short palm and broad, flattened little-gaping fingers which form an effective shield when held before the body.

\section{Genus ARCHAEOPUS Rathbun}

Archaeopus Rathbun, Proc. U. S. Nat. Mus., vol. 35, 1908, p. 346 ; type and only species, A. antennatus Rathbun.

Sides of carapace converging anteriorly, posterior angles rounded. Rostrum linear; orbits deep and wide. Basal article of antennules very large, inflated, and much exposed. Buccal cavity wide (pl. 4, fig. 6 ; pl. 6, fig. 2). Chelipeds moderate, fingers long and slender. Last pair of legs very small, subdorsal and probably attached at the margins of the abdomen the base of which does not cover the whole width of sternum (pl. 4, fig. 7; pl. 6, fig. 4).

\section{ARCHAEOPUS ANTENNATUS Rathbun}

Plate 4 , figs. $4-7$; plate 5 ; plate 6 , figs. $2-4$

? Small crab, GABB, Palaeontology of California, vol. 2, sec. 2, 1869, p. 127, pl. 19, fig. 1; original not extant; Martinez, Contra Costa County, in coarse-grained gray sandstone; Cretaceous.

Archaeopus antennatus Rathiun, Proc. U. S. Nat. Mus., vol. 35, 1908, p. 347 , pl. 47 , figs. $4-7$; pl. 48 ; pl. 49 , figs. $2-4$.

Description.-Surface punctate, uneven (pl. 4, fig. 5; pl. 5, fig. 1); a transverse ridge across cardiac and branchial regions; cervical suture well marked; a broad $\boldsymbol{H}$ in center of carapace; a groove parallel to posterior margin defines intestinal region. Elevations granulate. A conical tubercle crowns hepatic region, another on its margin; four on branchial margin, the anterior the largest, the posterior next in size. Each orbit is about one-fourth the anterior border of carapace (pl. 4, fig. 4); its maximum height, at its middle, nearly as great as its transverse width; upper margin with a triangular tooth near inner angle (pl. 5, fig. 1), a more prominent tooth at outer angle

${ }^{8}$ Rathbun, Proc. Washington Acad. Sci., vol. 4, 1902, p. 277, pl. 12, figs. 3 and 4. 
(pl. 4, fig. 5), lower margin with a tooth at inner end (pl. 5, fig. 2). Basal article of antennules swollen (pl. 5, fig. 2). Chelae of female narrow, strongly arcuate, fingers longer than palm, very slender, grooved, edges meeting, their teeth low (pl. 5, figs. 2 and 3). Cheliped remote from first ambulatory (pl. 5, fig. 3).

Measurements.-Holotype female, length of carapace $24.5 \mathrm{~mm}$, width $34.5 \mathrm{~mm}$., width between anterior angles $27.5 \mathrm{~mm}$.

Occurrence.-California; Bolsa Point, 1 mile north of Pigeon Point, San Mateo County; Loc. 27, Santa Cruz quadrangle; Chico formation, upper Cretaceous series. Holotype, adult female (Cat. No. 31069, U. S. N. M.) ; paratypes, one immature female, one male.

\section{Family GRAPSIDAE Dana}

Carapace usually quadrilateral, lateral borders either straight or slightly arched, orbits at or near antero-lateral angles, front broad. Buccal cavern square; generally a gap between outer maxillipeds; the palp articulates either at antero-external angle or at middle of anterior border of merus. Interantennular septum broad. Division of orbit into two fossae accented. Male openings sternal.

\section{Genus HEMIGRAPSUS Dana}

Hemigrapsus Dana, Amer. Journ. Sci., ser. 2, vol. 12, 1851, p. 288; type, H. crassimanus Dana.-Rathвun, Bull. U. S. Nat. Mus., No. 97, 1918, p. 264 .

Carapace transverse, quadrate, antero-lateral margin rounded and dentate; an oblique ridge runs inward and backward from posterolateral margin. Chelipeds stout, subequal; fingers hollowed out on the prehensile surface. Sternum much wider than base of abdomen.

Pliocene-Recent. Not before found fossil.

\section{HEMIGRAPSUS, species}

Plate 7 , fig. 3

Description.-The great width of the sternal segments indicates one of the Grapsidae and in particular the genus Hemigrapsus, two of whose species are now very abundant on the Pacific coast of North America. The first sternal segment is coarsely punctate, the second and third are finely punctate on the posterior half, while a few granules are scattered over the whole surface. Third, fifth, and sixth abdominal segments granulate. The depressions between the segments in the actual crab are here represented by ridges and the abdomen is below the level of the sternum, or the reverse of the position in the crab. The impression of a manus embraces apparently the inner surface, which is coarsely punctate except near the 
lower distal end where it is smooth. It must be borne in mind that punctae of an impression represent granules in the actual object and vice versa.

Measurements.-Male, length of second sternal segment close to abdomen $3.8 \mathrm{~mm}$., width of same $11.7 \mathrm{~mm}$., length of second sternal segment $5.3 \mathrm{~mm}$., width of same $11.6 \mathrm{~mm}$., length of fifth abdominal segment $5.4 \mathrm{~mm}$., length of sixth abdominal segment $6.7 \mathrm{~mm}$.

Occurrence.-California: $5 \frac{1}{2}$ miles southeast of Santa Rosa, three-tenths of a mile upstream from bridge crossing Matanzas Creek, on the left bank, four-tenths of a mile north of Grangers Hall, Sonoma County; Pliocene (?) series; one specimen showing an impression of a part of sternum and male abdomen; also impression of a palm which may not belong to the same individual.

This specimen was at one time encased in a nodule which later was broken and eroded until finally the crab itself was liberated. The triangular, compressed, waterworn fragment in hand contains the remnants (impressions or fragments) of about half a crab, the right half, three smaller openings showing evidences of ambulatory legs while the larger openings expose the position of the manus and the ventral surface of the body as described above.

HEMIGRAPSUS NUDUS (Dana)

Pseudograpsus nudus Dana, Proc. Acad. Nat. Sei. Philadelphia, vol. 5, 1851, p. 249.

Hemigrapsus nudus Schмiтt, Univ. California Publ. Zoöl., vol. 23, 1921, p. 273, pl. 47, text-fig. 161, and synonymy.-T. S. Oldroyd, Proc. U. S. Nat. Mus., vol. 65, art. 22, 1924, p. 23.

Occurrence.-California; Pleistocene series:

Nob Hill (lumber yard), northeast of San Pedro; lower San Pedro formation; 17 movable fingers; Cat. No. 353359, U.S.N.M.

Deadman Island, southeast of San Pedro; six movable fingers.

Signal Hill (or Los Cerritos), northeast of Long Beach; upper San Pedro formation; one movable finger.

Spanish Bight, San Diego Bay; one left manus, fingers and wrist of a small specimen; Cat. No. 353358, U.S.N.M.

Range of Recent specimens.-From Sitka to Gulf of California.

\section{HEMIGRAPSUS OREGONENSIS (Dana)}

Pseudograpsus oregonensis DanA, Proc. Acad. Nat. Sci. Philadelphia, vol. 5, 1851 , p. 248.

Hemigrapsus oregonensis Schмптт, Univ. California Publ. Zoöl., vol. 23, 1921, p. 274 , pl. 48 , text-fig. 162 , and synonymy.-T. S. Oldroyd, Proc. U. S. Nat. Mus., vol. 65 , art. 22,1924 , p. 23.

Occurrence.-California; Pleistocene series:

$3020-26-4$ 
Nob Hill (lumber yard), northeast of San Pedro; lower San Pedro formation: 70 movable, 14 immovable fingers; Cat. No. 353360 , U.S.N.M.

San Pedro; two movable, two immovable fingers; Cat. No. 353378, U.S.N.M.

Deadman Island, southeast of San Pedro; three movable, three immovable fingers.

The specimens enumerated above are probably in part $H$. nudus, as they are much worn and difficult to determine.

Range of Recent specimens.-From Prince William Sound, Alaska, to Todos Santos Bay, Lower California.

\section{Family PINNOTHERIDAE de Haan}

Of small size. Carapace often more or less membranaceous, anterolateral margins entire or very slightly dentate. Front, orbits, and eyestalks very small, corneae sometimes obsolescent. Buccal cavity usually very wide, often semicircular. Merus of outer maxilliped never quadrilateral, the palp never attached distinctly at anterointernal angle; ischium usually small, sometimes absent or fused with merus. Interantennular septum a thin plate. Male abdomen very narrow. Male openings sternal.

\section{Genus PINNIXA White}

CLAM CRABS

Pinnixa White, Ann. Mag. Nat. Hist., vol. 18, 1846, p. 177 ; type, P. cylindrica White.-Rathbun, Bull. U. S. Nat. Mus., No. 97, 1918, p. 128.

Carapace much wider than long; front narrow; orbit broadly ovate or nearly circular, eyes small. Merus of outer maxilliped large, ischium very small, palp large. Cheliped stout, palm compressed. Third ambulatory leg longest, second next.

Eocene; Recent. Not before found fossil.

PINNIXA EOCENICA, new species

Plate 1, figs. 3 and 4

Description.-Carapace transversely oblong (pl. 1, fig. 3), broadest at the middle, the antero-lateral margins strongly arched, the posterior margin slightly convex; surface very convex antero-posteriorly, almost level from side to side, hinder portion steep (pl. 1, fig. 4). The groove separating the gastric from the hepatic and branchial regions is broad and deep and is continued part way beside the cardiac region. Branchio-hepatic line little marked. Surface except in the depressions finely granulate, the granules higher and rougher on the posterior two-thirds of the branchial region. 
Branchio-cardiac border separately raised and crossed by many short, fine wrinkles. Epigastric lobes faintly marked; anterior end of mesogastric region outlined. Behind front and orbits a shallow, transverse depression. Antero-lateral margin drawn to a thin sharp edge. Outer angle of orbit obtuse, shallow, little advanced. Front divided in two by a deep median thumb-nail impression, and from the orbit by a broader depression; edge convex. Upper margin of orbit nearly transverse. Orbits looking forward, tapering outwardly, filled by the eyes.

Measurements.-Holotype, length of carapace $6 \mathrm{~mm}$., width of same $8.4 \mathrm{~mm}$., fronto-orbital width $4.3 \mathrm{~mm}$., width of front $1.8 \mathrm{~mm}$.

Occurrence.-Washington: West bank of Olequa Creek about oneeighth mile north of Vader Station, Lewis County; section 29, township 11 north, range 2 west; Eocene series; one carapace, holotype, in University of Washington.

Relation.-In its oblong shape this species is comparable to that of the female of $P$. faba, now living on the coast of Washington including Puget Sound, but faba is a smooth species without an antero-lateral rim, or any striking features of the carapace.

\section{Family GONEPLACIDAE Rathbun (GONOPLACIDAE Dana)}

Palp of external maxillipeds articulating at or near antero-internal angle of merus; exognath of normal size and not concealed. Interantennular septum a thin plate. Division of orbit into two fossae usually not indicated. Genital ducts of male usually perforate base of last pair of legs, often passing forward through a groove in sternum.

\section{Genus PLAGIOLOPHUS Bell}

Plagiolophus Bell, Monog. Fossil Malac. Crust. Great Britain, 1857 (publ. April, 1858), p. 19 ; type, P. wetherelli Bell, 1857.

Carapace transverse, ovate, regions distinct; front prominent; orbits opening forward, above bifissured, extending outward as far as middle of hepatic region. Basal article of outer antenna closing orbit. Chelipeds of medium size, fingers elongate.

Cretaceous; Eocene Pli e.

PLAGIOLOPHUS WEAVERI, new species

Plate 9 , figs. 5 and 6

Cancer? species Weaver, Univ. California Publ. Geol., vol. 4, No. 5, 1905, p. 123 , pl. 13, fig. 11 .

Cancer (?), species a Dickerson, Univ. California Publ. Geol., vol. 9, No 17, 1916, pp. 427, 434, 516, pl. 42, fig. 11.

Description.-Carapace broad, antero-lateral margins short, half as long as postero-lateral margins, which are moderately convergent

${ }^{9}$ Dana. Proc. Acad. Nat. Sci. Philadelphia, vol. 5, 1851, p. 253 [7]. 
(pl. 9, fig. 6). Surface lobulate, as follows: One hepatic lobule, obliquely transversely oval; one epibranchial, parallel to the hepatic but wider, and having partly attached to its inner end at right angles a small mesobranchial lobule which occupies the inner angle of the branchial region; the metabranchial region is almost covered by a large lobule. The protogastric lobes each have two linear parallel tubercles, the inner pair longer than the outer and near the inner edge of the subregion, the outer pair rising in the middle to a subacute tubercle; narrow part of mesogastric region constricted, end acuminate, terminating in a broad frontal furrow; metagastric lobes each crossed by an oblique line of about seven coarse granules. The cardiac region bears three acute tubercles forming an equilateral triangle, the posterior tubercle median. The regions and most of the lobules are separated by deep, broad furrows and are covered with fine depressed granules. The three antero-lateral teeth are set off by a furrow; the first or orbital tooth points forward, the second is shorter and points obliquely forward and outward; while the third, at the lateral angle, is directed outward and upward. Outside the epibranchial lobe there is a small low lobule just above the postero-lateral margin beyond which it does not project. Front well advanced beyond orbit, subtruncate, medially furrowed; the orbital margin slopes gradually backward to the outer tooth, except for a shallow prominence near its middle; eyestalk stout (3993). Posterior margin concave between attachments of legs of last pair.

The smallest specimen (5682) is less than $5 \mathrm{~mm}$. long; the lobules are arranged as in the holotype, the front is advanced and subtruncate, details of lateral teeth are obscured.

The largest specimen-that figured by Weaver-shows the entire outline of the orbit with its strong, outer, conical tooth, also the lateral teeth and areolations of the carapace (pl. 9, fig. 5).

Measurements.-Length of carapace of holotype in median line, front probably incomplete, $14 \mathrm{~mm}$.; greatest width of same, at last pair of lateral teeth, $20 \mathrm{~mm}$; width across front and orbits $17 \mathrm{~mm}$. Width of carapace of specimen from Loc. 1817, $23.2 \mathrm{~mm}$.; of carapace $\frac{542}{11891}, 28.2 \mathrm{~mm}$.

Occurrence.-California; Eocene series:

Salt Creek, 31/4 miles north-northeast of Joaquin Rocks, Fresno County; south part of northwest quarter, section 15, township 18 south, range 14 east; Eocene series; 1909; one carapace, holotype; Cat. No. 353351, U.S.N.M.

Salt Creek, 81/2 miles northwest of Oil City, Fresno County; carapace of very small specimen; Cat. No. 353352, U.S.N.M.

Southeast quarter of northwest quarter of section 15 , on branch of Salt Creek, township 18 south, range 14 east, Mount Diablo base line and meridian, Coalinga Quadrangle, Fresno County; near base 
of Tejon formation, middle Eocene, 75 to 100 feet above chocolate shales of probably Chico age, in a glauconitic sandstone stratum in clay shale; eight specimens, one of which is figured by Dickerson.

Salt Creek, southwest quarter, section 10; middle Eocene; dactyl of ambulatory leg which may belong to this species; Cat. No. 353639, U.S.N.M.

About 4 miles south of Martinez and east of the road to Walnut Creek, Contra Costa County; upper beds, Martinez formation; one specimen, figured by Weaver.

Two miles east of La Jolla, in bottom of Rose Creek where the creek makes a strong bend to the west; just west of the Brick Plant. On the La Jolla topographic sheet, 0.2 mile south of B. M. 176; middle Eocene; one small specimen and impression.

Relation.-P. wetherelli Bell, ${ }^{10}$ the type of the genus, from the Eocene of southeastern England, has lobules of different shape and an additional antero-lateral tooth or lobe.

\section{PLAGIOLOPHUS VANCOUVERENSIS Woodward}

Plate 20, figs. 1 and 2

Plagiolophus vancouverensis Woodward, Quart. Journ. Geol. Soc. London, vol. 52,1896 , p. 227 , text-figs. 5 and 6.-Whiteaves, Mesozoic fossils, vol. 1, pt. 5; Geol. Surv. Canada, Ottawa, 1903, p. 315, text-figs. 15 and 16.

Type-localities.-British Columbia; Comox River, Vancouver Island, and Hornby Island; Cretaceous. Specimens in Provincial Museum, Victoria, and in Museum of the Geological Society of Ottawa.

\section{Genus PILUMNOPLAX Stimpson}

Pilumnoplax Stimpson, Proc. Acad. Nat. Sci. Philadelphia, vol. 10, 1858, p. 93 ; type, P. sulcatifrons Stimpson.-Rathbun, Bull. U. S. Nat. Mus., No. 97, 1918, p. 21.

Carapace hexagonal, depressed; fronto-orbital border two-thirds as broad as the carapace; antero-lateral margin dentate; front straight. Chelipeds more massive than legs; legs slender, dactyli compressed.

Eocene; Oligocene; Recent. Not before found fossil.

KEY TO THE FOSSIL SPECIES OF PILUMNOPLAX

$A^{1}$. Third and fourth antero-lateral teeth of carapace acute, third prominent hannibalanus, p. 39 .

$\mathbf{A}^{2}$. Third and fourth antero-lateral teeth blunt.

$B^{1}$. Edge of front not dentate. First antero-lateral tooth (at outer angle of orbit), subrectangular; second tooth low, scarcely distinguishable from outer slope of first tooth, with which it is fused.

carmanahensis, p. 38 .

${ }^{10}$ Monog. Foss. Malac. Crust. Great Britain, pt. 1, 1857 (publ. April, 1858), p. 19, pl. 2, figs. 7-13. 
$B^{2}$. Edge of front bilobed, each lobe with a small tooth at inner angle. First antero-lateral tooth acute; second tooth or lobe with a long posterior slope soledadensis, p. 41.

PILUMNOPLAX CARMANAHENSIS, new species

Plate 9, figs. 1-4

Description.-The dorsal surface of carapace and chelipeds has been worn or ground off (pl. 9, fig. 2); the regions are fairly well shown especially the hepatic region which is nearly oblong, its anterior margin appearing like a ridge above the deep furrow behind the orbit; this furrow is continued around the orbits and front. Gastric region well marked, and also the anterior part of the mesogastric region which is very narrow with parallel sides and then tapers gradually to a sharp point; cardiac and metagastric regions indistinct. A linear median impression on the surface of the front; a broad furrow separates the surface of the front from that of the orbit. Edge of front transverse; orbit oblique, its details obscure; outer angle of orbit almost a right angle and.much less advanced than the front. Including the orbital tooth there are on the lateral margin five teeth or protuberances as there are also in most of the Panopeids; the second is a shallow lobe which is fused with the first or orbital tooth to form a sinuous margin; the last three teeth are dentiform, thick and blunt, the last one the smallest, about opposite the widest part of the metagastric region.

Chelipeds very unequal, the right the larger (pl. 9, fig. 3). Its merus extends obliquely forward to the line of the front, and is thick and high, the outer surface rounding into the lower surface; just within the oblique distal margin of the outer surface there is a deep smooth furrow, and the lower distal angle is produced in a prominent articulating lobe set off by a groove; surface of merus irregularly granulate. Carpus also granulate on the small piece of surface remaining (pl. 9, fig. 1); the angle of the inner margin is situated behind its middle, as is so frequently the case in this and related genera; a deep furrow parallel to distal margin. Manus very high, moderately compressed, widening distally, upper surface convex, smoothly rounded, lower margin nearly straight, surface covered with very fine granules arranged in a reticulating pattern. Of the fingers only a small bit of the proximal end of each remains; they are black and more closely granulate than the palm; the dactylus shows a superior punctate groove and a deeper lateral (outer) groove, also a row of punctae between grooves. The merus of the left or minor cheliped reaches very little farther forward than the third of the five lateral teeth of the carapace; the carpus has in its dorsal aspect less than half the area of the major carpus; while the palm is only about half as high as the major palm, is consider- 
ably shorter and its granulation coarser, the upper margin is convex, the lower sinuous. The fingers are long, narrow, slightly deflexed, meeting when closed or nearly so; they are black except the base of the dactylus, longitudinally deeply grooved, a row of punctae in each groove; intervening ridges high; two ridges on outer surface of each finger while a third ridge is visible above the dactylus; prehensile edges dentate; on the fixed finger there are three larger subacute teeth with concave sides, with one or two small teeth in the interspaces.

The merus of the first left ambulatory leg reaches forward nearly as far as the carpus of the cheliped (pl. 9, fig. 4).

Measurements.-Holotype male, width of carapace $23.3 \mathrm{~mm}$., length (approximate) $19 \mathrm{~mm}$., width of front $7.4 \mathrm{~mm}$., transverse width of orbit $4 \mathrm{~mm}$., superior length of major manus $11.6 \mathrm{~mm}$., height of same $11 \mathrm{~mm}$., height of major merus $6.7 \mathrm{~mm}$., superior length of minor manus $7 \mathrm{~mm}$., height of same $6 \mathrm{~mm}$.

Occurrence.-British Columbia: Sandstone shale sea cliffs for 3 miles west of Carmanah Point, Vancouver Island; Oligocene series; one specimen ${ }^{11}$ showing carapace and chelipeds, holotype, in Stanford University.

Relation.-This has many points in common with P. americana, ${ }^{12}$ as, for example, the straight front, oblique orbits, very unequal chelipeds, one massive, the other narrow and more coarsely granulate; above all the fingers of the small chela correspond to those of the Recent species in the character of the grooves and ridges and the dentation of the immovable finger.

PILUMNOPLAX HANNIBALANUS, new species

Plate 10, figs. 1-4

Description.-Carapace chiefly flat and little areolated (pl. 10, figs. 1 and 3 ). The branchial regions are slightly swollen, the surface is deflexed along the postero-lateral borders, the antero-lateral teeth are slightly upturned. Surface a little depressed behind front and orbits; between this depression and the angle of the front a short oblique groove; a deep furrow forming the sides of an hourglass at the gastro-cardiac regions; and outside of, and parallel to that, a narrow swelling. Some fine granulation evident along anterior and antero-lateral margins.

Margin of front slightly arcuate forward, corners deflexed; margin of orbit very oblique, somewhat concave, a suture leading almost

11 This and all other specimens derived from the "N. Pac." survey by Stanford University were submitted to the author by Prof. Bruce L. Clark, of the University of California.

${ }^{13}$ Pilumnoplax americanus Rathbun, Bull. Lab. Nat. Hist. State Univ. Iowa, vol. 4. 1898 , p. 283 , pl. 7 , figs. 1 and 2. 
straight back at its outer third; outer angle not dentiform, scarcely advanced, so that the orbit is very slightly separated from the antero-lateral margin. Coalesced (first plus second) tooth a little longer than orbit, with slightly concave edge, outer corner subrectangular; third tooth projecting more than half its length beyond the second, anterior margin a little concave, oblique, posterior margin strongly convex, tip acute; fourth tooth appears to be similar but smaller; the fifth tooth still smaller ( $f$, pl. 10, fig. 1$)$. Posterolateral margins arcuate, convergent, posterior margin sinuous, concave at middle.

Chelipeds very unequal, the right the larger. Surface granulate. Merus stout, upper margin bearing a distal and a subdistal tooth ( $d$ and $s$, pl. 10, fig. 1) separated by a deep transverse groove. Carpus also with a deep subdistal groove and a conical acute inner spine. Major manus with very convex outer surface; border thick, without marginal line, gradually rounding from the outer to the inner surface, and in profile slightly arcuate; lower border nearly straight, slightly sinuous; proximal end very oblique, terminating at either corner in a backward-pointing lobe, the lower one especially produced (pl. 10, fig. 2 ) ; distal end partly visible, a large lobe ( $l$, pl. 10, fig. 2) overlapping the outer surface of the dactylus. The base of the dactylus is light-colored; a stout basal tooth is black and points backward, it is followed by seven other teeth which are indicated only by impressions in the matrix; the first of these is largest but smaller than the basal tooth, the other teeth are irregular in size. Of the minor chela only the upper portion of the manus and the white and granulate basal end of the dactylus are visible. A slender merus ( $m$, pl. 10, fig. 2 ) of the first right ambulatory reaches as far as the arm alongside.

Paratype a.-This specimen of the same width as the holotype agrees with it in the main so far as it goes. A band of closer granuiation than that of the general surface borders the front and anterolateral margins. The outer orbital angle is more pronounced, forming a small forward-pointing tooth. The third lateral tooth does not extend so far beyond the second tooth (or lobe) as in the holotype, the fourth extends a shorter distance beyond the third, while the fifth does not project at all beyond the fourth. The narrow portion of the mesogastric region is faintly outlined; it tapers gradually to an acuminate point. The left appears to be the major cheliped, the merus (pl. 10, fig. 4) measures $11.4 \mathrm{~mm}$. long above, and the impression of the chela $27 \mathrm{~mm}$. long below.

Paratype b.- The frontal and right antero-lateral portion of the carapace of a larger specimen remain, but much defaced. The outer orbital angle is stronger than in paratype $a$ and the relation of the third to the second lateral tooth is the same as in that specimen. 
Measurements.-Holotype, male (probably), length of carapace $25 \mathrm{~mm}$., width of same between tips of teeth of last pair $31.2 \mathrm{~mm}$., width of front $12 \mathrm{~mm}$., oblique width of orbit $4.3 \mathrm{~mm}$., superior length of major manus $12 \mathrm{~mm}$., height of same $10.6 \mathrm{~mm}$., length of dactylus exclusive of tip broken off $12 \mathrm{~mm}$., superior length of minor manus $8.6 \mathrm{~mm}$.

Occurrence.-Washington: Conglomerate sea cliffs at Koitlah Point west of Neah Bay; lower (?) Oligocene series; one specimen, paratype $a$, showing half the carapace and part of the chelipeds.

Washington: Sandy shale bluffs along Cowlitz River, 11/2 miles below mouth of Drew Creek, Olequa; Eocene series; one specimen, paratype $b$, showing a fragment of carapace, of arm and of merus of three ambulatory legs.

Oregon: Basalt tuffs cut on the Tillamook branch, Southern Pacific Railway, one mile east of Wheeler, Nehalem Bay; middle (?) Oligocene series; one specimen, holotype, showing a large part of carapace and chelipeds; in Stanford University.

Relation.-This species differs from $P$. carmanahensis in the flat hepatic region, more arched front, shallower orbit, subrectangular second antero-lateral tooth, and elongate hand.

PILUMNOPLAX SOLEDADENSIS, new species

Plate 12

Description.-One male specimen (holotype) embedded in rock, showing dorsal view of carapace and portions of chelipeds and legs. The sternum was broken from its place and is turned backward behind the carapace. An impression of the same specimen shows the outline of the front and bears the actual movable finger of the major cheliped. Surface of carapace finely roughened with depressed granules. Mesogastric region defined by shallow furrows, from it a median furrow runs to the front margin. A swelling behind each lobe of the front; lobes well separated by a $U$-shaped interspace, their edges granulate, slightly oblique and sinuous, each lobe with a small, prominent tooth at inner angle, which is separated by a shallow sinus from the rounded outer corner (pl. 12, fig. 2). Outer angle of orbit acute, its outer margin fused with the second antero-lateral tooth forming an obtuse angle; third tooth slightly obtusangled, its anterior margin two-thirds as long as posterior; fourth tooth similar, but anterior margin shorter; fifth tooth very small, rectangular, directed outward. Postero-lateral margin longer than antero-lateral, convex (pl. 12, fig. 1).

The chelipeds appear unequal, the right the larger; the right merus has a blunt, superior subdistal tooth; the left carpus is of equal width and length, with an inner marginal spine halfway back; 
the right dactylus (pl. 12, fig. 2) is almost black, its inner surface is visible, a deeply impressed line is parallel and close to the upper margin; lower down there is a broader groove on the proximal half; a huge, blunt, subconical basal tooth is directed obliquely inward, downward and backward; remaining teeth unequal, the first and third from the basal tooth being the largest; the dactylus gradually narrows and curves well down at the extremity. The merus of the ambulatory legs narrows rapidly at the proximal end and gradually at the distal end.

Measurements.-Male holotype, length to median sinus of front $22.8 \mathrm{~mm}$., width at level of fourth (next to the posterior) tooth $29 \mathrm{~mm}$., fronto-orbital width $15.9 \mathrm{~mm}$., width of front $7.9 \mathrm{~mm}$., length of merus of an ambulatory (perhaps third) leg $19.8 \mathrm{~mm}$., length of dactylus of major cheliped $11.8 \mathrm{~mm}$.

Occurrence.-California: 21/2 miles south of the mouth of Soledad Valley in the sea cliff; on the La Jolla topographic sheet, due west of half way between the " $p$ " and " $u$ " in Pueblo (south of the mouth of Soledad Valley) in sea cliff facing ocean. Eocene series. Holotype in University of California.

\section{Genus BRANCHIOPLAX Rathbun}

Branchioplax Rathbun, Amer. Journ. Sci., vol. 41, 1916, p. 344; type, B. washingtoniana Rathbun.

Carapace a little broader than long; anterior margin arcuate. Orbits of moderate size, broadly oval, looking straight forward; eyes stout, filling orbits. Antero-lateral margins dentate, shorter than postero-lateral margins which are moderately convergent with the posterior angles rounded. Front not emarginate. Regions well defined, branchial regions swollen dorsally and approximate. Chelipeds unequal, of moderate length, carpus not much broader than long, manus high. Related to Eucrate de Haan; ${ }^{13}$ type $E$. crenata de Haan, a Japanese species.

Contains only one species.

\section{BRANCHIOPLAX WASHINGTONIANA Rathbun}

Plate 9, fig. 7

Branchioplax washingtoniana RathBun, Amer. Journ. Sci., vol. 41, 1916, p. 345 , 1 text-fig.

Description.-Surface of carapace everywhere granulate, the granules running larger and higher toward the margins and especially on the postero-lateral slope. The depressions in the center of the carapace on either side of the gastro-cardiac area are deep.

${ }^{13}$ Fauna Japon., Crust., 1835, p. 36. 
Metabranchial lobe large and dorsally much swollen, separated by a curved, transverse furrow from the mesobranchial lobe which in turn is separated from the hepatic and epibranchial lobes by a furrow subparallel to the other. Epibranchial lobe depressed, hepatic region low; anterior half of the narrow mesogastric lobe well defined. A shallow furrow separates the epigastric lobes. An oblique lobe at inner angle of branchial region.

Outlines: Margin of front slightly arcuate and unevenly granulate. A furrow between upper surface of front and of orbit. Outer angle of orbit obtuse, from it the lateral margin is oblique and nearly straight for a ways and ends in a rounded, nonprojecting lobe, which is separated from the next tooth by a closed fissure; three similar acute teeth, two of which are of good size, the last one small and little projecting; it is right angled and has a sharp horny tip. These teeth are perfect only in the Stewart specimen. Of the other specimens only two (males out of 2938 and 167) have the last tooth developed (pl. 9, fig. 7). Of the postero-lateral margin that portion bordering the mesobranchial lobe is straight and directed somewhat inward and backward, the margin of the metabranchial lobe is arcuate and curves into the posterior margin, which is slightly arcuate and in the middle nearly straight.

Appendages: Only a hint is given, in one specimen of No. 167, of the form of the outer maxillipeds; the ischium appears broad and its inner margin strongly curved; only the outer half of a merus is shown, it is not dilated at the outer angle. The unequal chelipeds are stout, the merus projects little beyond the body, the carpus is rounded and has a bluntly rounded inner angle, perhaps not a tooth; manus thick, dactylus stout. The separate dactylus, No. 4135, is about $14 \mathrm{~mm}$. long, tip excluded, tapers from a stout base to a slender extremity and has a large, backward-pointing, appressed, basal tooth followed by five smaller low teeth, all rounded. Surface of chelipeds and merus of ambulatory legs granulate.

Ventral surface: The sternum is very elongate and has a transverse furrow between the bases of the maxillipeds and an obtuse angled and slightly curved furrow between the bases of the chelipeds. Sternum granulate, abdomen of male smooth and coarsely punctate except the first and outer ends of the second and third segments which are granulate. The abdominal segments are all distinct; the first and third are about the same width, the second and third are the same length at the middle, the fourth and fifth a little longer, subequal; the sixth and seventh still longer and subequal; the fourth, fifth, and sixth segments taken together are suboblong, narrowing but little, the seventh is subtriangular, about twice as wide as long.

Measurements.-Largest specimen, male No. 4135, length $45 \mathrm{~mm}$., width $47 \mathrm{~mm}$., merus of second ambulatory leg $26 \mathrm{~mm}$. 
Occurrence.-Alaska: West end of Bering Lake; probably Oligocene; six specimens, mostly impressions; Cat. No. 353326, U.S.N.M.

Washington: Port Townsend; "late Tertiary"; Clallam formation, lower Oligocene series, according to B. L. Clark; one specimen, holotype, in Yale Museum; plastotype in United States National Museum.

Washington: Conglomerate seacliffs at Koitlah Point, west of Neah Bay; lower (?) Oligocene series; three males without appendages.

Washington: In shale near station 214, Koitlah Point, 11/4 miles northwest of Neah Bay, Clallam County; "Oligocene-Miocene," one male and impression; also a finger which may belong to the same species. Cat. No. 353327, U.S.N.M. This crab was at one time enclosed in a nodule; subsequently the nodule split in two exposing the dorsal surface of the body and some of the legs which later became thinly encrusted with mud which hardened; by erosion the anterior part of the dorsal surface of the body was worn away leaving the antennules, interantennular septum and bases of antennae visible from above; the body has since been broken away from the nodule exposing its ventral surface and an impression of the same.

Washington: 11/2 miles east of Vader, Lewis County, in the bank of the Cowlitz River, just below the big bend; Cowlitz formation, upper Eocene; one male, with the sternum and a small part of the carapace exposed.

Washington: Southwestern part, at the type-locality of the Cowlitz formation, upper Eocene; one male, body only, in which the outer shell of the dorsal surface of the carapace is well preserved except in the anterior and antero-lateral portions.

\section{Genus EUCRATE de Haan}

Eucrate de HaAN, Fauna Japon., Crust., 1835, p. 36 ; type, Eucrate crenata de Haan.

Carapace deep, subquadrilateral, convex fore and aft; frontoorbital border nearly as broad as carapace; antero-lateral borders toothed and slightly arched; front straight. Orbital hiatus closed by a process from basal antennal joint. Chelipeds much more massive than legs. The third abdominal segment of male covers the whole width of the sternum.

Oligocene; Recent. Not before found fossil.

EUCRATE MARTINI, new species

Plate 8, figs. 2 and 3

Description.-Front nearly straight, rounded at the corners (pl. 8, fig. 3). Outer angle and lower inner angle of orbit equally 
advanced but not reaching line of front. Inner angle of orbit swollen, conical. Antero-lateral teeth small, blunt, obscure, apparently three in number, almost equidistant from the orbital angle and one another. Basal article of antennules much swollen in the outer half; narrow portion of interseptum with subparallel sides. The basal article of the antennae does not reach the edge of the front. Ischium of outer maxillipeds narrow behind, increasing in width distally; a deep, straight, impressed line, subparallel to and near the inner margin (pl. 8, fig. 2). Merus very uneven, a deep oval depression on inner half; a small emargination at the inner angle for the palp; otherwise quadrangular. Sternum rather narrow; a deep obtuse-angled groove unites the anterior bases of the chelipeds. The abdomen as now folded nearly reaches this groove; terminal segment two-thirds as long as broad, end rounded; penult segment about two-thirds as long as the last; fourth and fifth segments much shorter.

The chelipeds of the female are of moderate size, unequal. 'The merus stretches its full length beyond the carapace; it is short and high and rises in a conical lobe above a little distad to the middle. Carpus large, longer than broad, inner angle well forward and seemingly unarmed. Manus of larger cheliped shorter than carpus, upper and inner surfaces convex, upper longitudinal outline arcuate. Merus of legs long and narrow, oval in section; a single dactylus is slender and strongly curved.

Measurements.-Female holotype, length of body from margin of front to line of attachment of second legs $25 \mathrm{~mm}$., greatest width of carapace $29.6 \mathrm{~mm}$., width between outer angles of orbits $15.7 \mathrm{~mm}$., width of front $8.6 \mathrm{~mm}$., distance between attachments of legs of second pair $16 \mathrm{~mm}$.

Occurrence.-Oregon: Rocky Point, 4 miles east of Yaquina City; Oligocene series; one female embedded in nodule so that the under side of body is exposed together with impressions of the chelipeds; the other half of the nodule shows the impression of the ventral surface of the body and the actual upper surface of the chelipeds in part. Holotype in California Academy of Sciences.

Relation.-I have placed this species in Eucrate on account of its general shape, the small teeth, the groove on the sternum, the short arms and palms. One must see the dorsal surface of the carapace to place it with certainty.

\section{Genus COELOMA A. Milne Edwards}

Coeloma A. Milne Edwards, Ann. Sci. Nat., Zool., ser. 5, vol. 3, 1865, p. 324 ; type, $C$. vigil A. Milne Edwards.

Carapace wider than long, fronto-orbital distance great; front dentate; orbits wider than front, bifissured above; antero-lateral 
margins short, dentate, postero-lateral margins convergent. Chelipeds stout. Ambulatory legs long, slender, compressed. Abdomen at base covers sternum between last pair of legs.

Eocene; Oligocene; Pliocene.

COELOMA MARTINEZENSIS, new species

Plate 11, figs. 1-3

Description.-The hexagonal carapace (pl. 11, fig. 2) is wider across the front and orbits than along the posterior margin, the postero-lateral margins being strongly convergent; the antero-lateral margin is about two-thirds as long as the postero-lateral. The gastric region is narrow, only one-third as wide as the carapace and is separated by a wide and deep furrow from the branchio-hepatic regions. Hepatic regions mostly swollen, defined posteriorly by a sinuous furrow running inward from behind the second lateral tooth, and by a pit half way between the end of that furrow and the gastric margin. The greater part of the branchial region is moderately swollen, a depressed area both in front of and behind the swelling. A deep median furrow proceeds from the mesogastric region to the edge of the front, while a shallower furrow embraces the inner part of the orbital region. The surface is covered with rather close set, prominent and unequal granules.

The front is less than one-third as wide as the fronto-orbital distance, it is deflexed, deeply bilobed, each lobe itself bilobed, but the exact shape of these lobules is obscure. The upper border of the broad orbit is directed slightly forward toward the outer tooth and shows distinctly two emarginations, between and behind which there is a small, triangular depressed area. The outer tooth points directly forward, its outer margin is longer than its inner, the next two teeth on the lateral margin are directed obliquely outward; these three teeth are nearly triangular with subacute tips; fourth or last tooth directed outward, tips broken off.

Chelipeds very unequal, the right the larger; merus joints projecting little beyond carapace; carpus broader than long, inner angle prolonged in a tooth or spine, outer angle blunt and rather prominent, upper surface covered with reticulating ridges. The larger palm (pl. 11, fig. 3 ) is very thick and very little longer, measured on its middle distance, than the fingers; it widens from the proximal to the distal end, the upper edge very convex, the lower sinuous to end of finger; lower third of outer surface of manus and also finger flat; remainder of manus very convex especially in a vertical direction. The propodal finger has a broad, basal half, its prehensile edge shows seven lobes, its thick tip is upcurved. The dactylus is curved, but may have fitted the immovable finger when closed against it, 
it bears a larger, backward-pointing, basal lobe, and several smallish lobes. The upper half of the minor palm appears of similar shape to the major one, its superior length is about four-sevenths that of the major palm.

Only the impressions of the merus of the first and second legs of the right side are visible; they are long and narrow, the second one reaching to the lateral spine of the carapace.

The sternum is nearly flat, the male abdomen small, with all seven segments distinct, the third segment reaching apparently across the sternum to the coxae of the hind legs (pl. 11, fig. 1).

Measurements.-Length of carapace, in median line, of male holotype $32 \mathrm{~mm}$.; width at sinus immediately in front of spine or tooth at lateral angle, this spine being incomplete on both sides of the carapace, $42.5 \mathrm{~mm}$. ; height of right or major manus near distal end $20.2 \mathrm{~mm}$.

Occurrence.-California; Rock Creek quadrangle; Martinez formation (the lowest Eocene formation of California); one male specimen, showing the greater part of the body and chelipeds; holotype, Cat. No. 353370, U.S.N.M.

Relation.-This species resembles most the type species of the genus, $C$. vigil A. Milne Edwards, ${ }^{14}$ from the Eocene of northern Italy. Our species differs in its narrower orbits and consequently more oblique antero-lateral margin, in the shorter postero-lateral margin (which in $C$. vigil is about twice as long as the antero-lateral margin); in the greater inequality of the chelipeds of the male ${ }^{15}$ and in the narrower abdomen of the male.

\section{Family XANTHIDAE Alcock}

Carapace more or less transversely oval; front moderately broad, often toothed, in the latter case always with a median notch; anterolateral margins arcuate, armed with several lobes, teeth or spines. Antennules fold back transversely or obliquely. Fingers of chelipeds more or less curved.

\section{Genus ZANTHOPSIS M'Coy}

Zanthopsis M'Coy, Ann. Mag. Nat. Hist., ser. 2, vol. 4, 1849, p. 162; type, Z. leachii (Desmarest).

Carapace very convex, oval, furnished with a definite number of large tubercles or bosses. A few tubercles or lobes on antero-lateral margin. Front quadrilobate. Chelipeds massive, fingers pointed. Third, fourth, and fifth segments of male abdomen fused.

Cretaceous; Oligocene.

${ }^{14}$ Ann. Sci. Nat., ser. 5. Zool., vol. 3, 1865, p. 324, pl. 12, figs. 1-3.

${ }^{15}$ See Bittner, Denksch. k. Akad. Wiss., math.-naturw. Cl., vol. 34, Abth. 2, Wien, 1875, pl. 5, figs. 1 and 3 . 
ZANTHOPSIS VULGARIS, new species

Plates 13 and 14

Description.--Outlines of carapace: Carapace very much arched from front to back, less so from side to side. Anterior and anterolateral margins form almost a semicircle (pl. 13, fig. 1); anterolateral margins very thick, cut into four lobes, the one nearest the orbit broad and shallow, the others increasing in prominence to the lobe at the lateral angle which is about midway of the length of the carapace. Postero-lateral margins moderately convergent, slightly convex. Front between a fourth and a fifth as wide as the carapace, with a triangular median sinus forming two oblique lobes, each composed of two teeth or lobes separated by a broad shallow sinus; the submedian teeth are rounded and larger than the outer teeth, which tend toward acuteness (pl. 13, fig. 2).

Areolation of carapace: The deepest furrows on the dorsal surface of the carapace consist of two crescentic, impressed lines separating the branchial from the metagastric-urogastric-cardiac regions. The postero-lateral borders of the cardiac region are marked by a wrinkled fold in a broad depression. The largest areole of the carapace occupies the posterior part (about half) of the branchial region and is subcircular and nearly as high, in many instances quite as high, as the cardiac region. ${ }^{16}$ The metagastric region, which is not separated from the narrow mesogastric region, lies at the highest part of the carapace; either side of it there is a small round branchial areole less high. Between this and the large areole and the crescentic groove there is a narrow, low, curved areole pointed behind. On the epibranchial region there is an oblong, elongate areole, obliquely tranversely placed, separated by the broad cervical suture from the postero-external angle of the protogastric region, and from the lateral marginal lobe by an equally deep furrow; this elongate lobe is a distinguishing feature of the species. The greater part of the hepatic region is occupied by a single elevation separated from the marginal lobes. The gastric subdivisions are separated by shallow furrows; the mesogastric region has an acuminate point from which a groove is continued to the frontal border. In specimens which have the outer layer of shell preserved, the areoles are shown to be abundantly but not closely covered with unequal granules, the interspaces are smooth. The coarsest granulation is on the posterolateral portions of the carapace.

Orbits, antennae, and maxillipeds: The orbit is broad-oval, its greatest length is about equal to half the width of the front. Edge

${ }_{16}$ The branchial lobes are often considerably swollen (pl. 14), having the appearance of being infested by a parasite. As the swellings are in each case equally developed on both sides of the carapace, their presence is more likely due to adaptation to an arid condition existing at the time of their destruction. 
of front and orbits granulate, granules interrupted just outside the outer tooth of the front and in the line of the closed fissure in the orbit. Outer angle of orbit not dentiform; inner inferior angle produced in a spine. The eyes appear to fill the orbits. Below and behind the outer, bent-down angle of the front lies the basal article of the antenna; while between the two is wedged the outer angle of the large, swollen, basal article of the antennula. The merus of the outer maxillipeds (British Columbia, No. 141) is broader than long, anterior and posterior margins subparallel, antero-external angle laterally produced, antero-internal angle notched; inner and outer margins of ischium subparallel, a deep, oblique furrow runs on the inner half, its distal end much nearer the inner margin than its proximal end; exognath in its widest part half as wide as ischium of endognath.

Sternum and abdomen: The sternum shows on its first or anterior segment, a deeply impressed groove on either side which starts at the anterior margin of the cheliped at its insertion and follows the line of that margin, the two grooves becoming shallow as they approach the median line, and meeting in an obtuse angle (pl. 13, fig. 3). A shallow groove begins at each of the postero-lateral angles of the same sternal segment, and runs obliquely forward and inward. In only one specimen, a female (N. Pac. 253) is the whole sternum exposed; the genital openings are very large, not quite round, with a diameter of about $4.5 \mathrm{~mm}$. parallel to the anterior margin of the segment and a diameter of $3.7 \mathrm{~mm}$. in the opposite direction.

In the male the seven abdominal segments are distinct; the third segment is widest; the abdomen diminishes rather uniformly from the middle of the third segment to the end of the sixth, the distal angles of which are advanced a little about the angles of the seventh segment; this segment is subtriangular, with slightly sinuous sides and a broadly rounded tip. The third, fourth and fifth segments are of subequal length although none of them is of uniform length throughout its width.

In the female the third segment is narrower than the fourth and its margins converge considerably at the outer ends. The fifth segment is a little longer than the fourth and of about equal width; in one specimen it appears a little wider, in another specimen not quite so wide as the fourth; the sixth is as wide as the fifth (pl. 13, fig. 3).

Chelipeds: The chelipeds are very unequal in the male; both are massive, their surface is granulated, the granules forming more or less into lines. The merus is stout, increases in size from the proximal to the distal end and has a broad and deep furrow parallel to the distal end. The carpus also has a subdistal furrow and a rounded, inner angle. The major palm is thick, oval in section, 
increasing in height from proximal to distal end, where a rounded lobe projects over the dactylus. Both fingers are a dark bluishblack except at the proximal end (British Columbia, No. 141); their horizontal length is less than the middle length of the paim; they are inclined gently downward, the tips curving toward each other and crossing; there are a few longitudinal rows of punctae; the longest tooth is at the base of the dactylus, succeeding teeth few and very shallow, lobiform; teeth or lobes on fixed finger five in number, diminishing in size toward extremity of finger.

The chelipeds of the female (pl. 13, fig. 3 ) are smaller in proportion to the size of the carapace than those of the male, and the palms are shorter and more rotund, not highest at the distal end (Washington, Nos. 187 and 253).

Ambulatory legs: These are long and slender (No. 253), differing: little in length. The coxa and ischium are granulate near the distal end. The merus is long, narrow, compressed, its cross-section twothirds as wide in its widest part as it is long, outer surface nearly smooth, a shallow furrow through the middle of the flat, posterior surface. The propodus is about half as long as the merus, its median furrow is deeper; the carpus is a little shorter than the propodus. The dactylus is probably about as long as the carpus, but the ends of all of them are lacking; the median groove is deeply impressed.

Measurements. - Width of carapace of type-specimen $49 \mathrm{~mm}$. Length of carapace in the median line (Oregon, No. 15) $37 \mathrm{~mm}$., width $45.4 \mathrm{~mm}$. Length of another from the same place 36.2, width $42.5 \mathrm{~mm}$. The largest carapace (Washington, No. 253) is about 74 mm. wide. The largest nodule containing a crab (Oregon, No. 948) has a major diameter of $19 \mathrm{~cm}$.

Relation.-This species is nearest to the type species of the genus, Z. Teachii (Desmarest, 1822; A. Milne Edwards) ${ }^{17}$ which also has a nodose carapace and four antero-lateral lobes of moderate size, but in leachii the posterior half of the branchial region is occupied by two small nodules instead of one large one as in vulgaris, and the epibranchial nodule is small and round instead of obliquely transversely elongate. In leachii the antero-lateral is longer in relation to the postero-lateral margin than in vulgaris.

Occurrence.-From the southern border of Vancouver Island, British Columbia, along the Strait of Juan de Fuca and southward along Puget Sound, thence eastward to Burnett and westward to Chehalis County, Washington, thence southward across the Columbia River to Lincoln and Lane Counties, Oregon.

The species appears to be distributed throughout the Oligocene and to be confined to that series.

\footnotetext{
${ }^{17}$ Ann. Sci. Nat., ser. 4, Zoöl., vol., 20, 1863, p. 315 , pl. 7, figs. 1 and 2 ; pl. 8 , figs. 3 and 4 ; pl. 11, fig. 4 .
} 
Near Pachena Bay, Vancouver Island; near the north point of entrance into the Strait of Juan de Fuca; Oligocene series, near boundary between Sooke and Carmanah formations; one specimen.

Sea cliffs $2 \frac{1}{2}$ miles south of Pachena Lighthouse, Vancouver Island; one specimen.

Basal sandstone sea cliffs between Clo-oose and Nitinat Lagoon, Vancouver Island; lower (?) Oligocene series; three specimens.

Sandstone and shale sea cliffs for three miles west of Carmanah Point, Vancouver Island; 11 specimens comprising 8 carapaces and 3 pieces of appendages.

Sandy shale sea cliffs at mouth of Five Mile Creek, Carmanah Point, Vancouver Island; three specimens.

Sandy shale from sea cliff as found about 1 mile west of Sevenmile Creek, Carmanah Point, Vancouver Island; eight specimens.

Sea cliffs between Kow Shet Cove and Nine Mile Creek, Strait of Juan de Fuca, Vancouver Island; two specimens.

WASHINGTON

Sandy shales in sea clifis 1 to 2 miles south of Eagle Creek, Port Discovery; two specimens.

Sandy shale sea cliffs and beach, south shore of Mystery Inlet, Scow Bay, Port Townsend; lower (?) Oligocene series; three specimens.

Sandstone and shale sea cliffs along west shore of Oak Bay, 1 to 2 miles south of Portage Spit between Port Townsend and Port Ludlow; lower (?) Oligocene; six specimens comprising two carapaces and four pieces of cheliped.

Northern Pacific Railway cut 100 feet east of Seattle Brewing and Malting Company's brewery at Georgetown, South Seattle, in section 20, township 24 north, range 4 east; four specimens.

Burnett, Pierce County. Labeled "Miocene"; probably Oligocene series, Puget formation; six specimens, Cat. No. 353395, U.S.N.M.

Bed of Delezene Creek 5 or 6 miles up stream from its junction with Chehalis River; two specimens.

Porter, Chehalis County; middle Oligocene series; seven specimens.

Bluffs immediately north and south of Porter; middle Oligocene series; two specimens.

Porter Creek, near Porter; middle Oligocene series; one specimen.

Shaly sandstone bluff on Chehalis River below Porter; middle Oligocene series; two specimens.

Porter, in bluff just below Railroad Station on Northern Pacific Railroad; section 22, township 17 north, range 4 west; middle Oligocene series; five specimens. 
Near Porter, section 22, township 17 north, range 5 west; middle Oligocene series; three specimens.

Marly tufis along bluffs at old log dam along Porter Creek; lower Oligocene series; associated with lowest fauna of Lincoln horizon, as defined by Dr. C. E. Weaver; one specimen; also two fingers.

Shaly sandstone bluffs one-fourth mile below old $\log$ dam on Porter Creek, Porter; middle Oligocene series; one specimen.

Shaly sandstone bluffs along Porter Creek, one-fourth to 1 mile above old log dam, Porter; middle (?) Oligocene series; one specimen.

Shaly sandstone bluffs along Porter Creek, three-fourths mile above Porter; middle Oligocene series; four specimens.

Bluff half a mile east of Porter Station; middle Oligocene series; Porter formation; one specimen.

Shaly sandstone road cuts one-fourth mile southeast of Porter along the Chehalis River; middle Oligocene series; nine specimens.

Sandy shale bluffs along the Chehalis River northwest of the mouth of Lincoln Creek; middle Oligocene series; three specimens.

About 5 miles northwest of Oakville, Chehalis County, in shales on Gibson Creek; two specimens, Cat. No. 353402, U.S.N.M.

Mill Creek, 11/2 miles east of junction with Willapa River and 3 miles northeast of Menlo, Pacific County; one female specimen.

Tuffaceous sandstone bluffs along the Willapa River north of Holcomb, Pacific County; middle Oligocene; 11 specimens.

About 1 mile north and a little east of Holcomb in east bank of Willapa River; six specimens.

One thousand six hundred feet above first railroad bridge on Willapa River, below Holcomb; section 25, township 13 north, range 8 west; four specimens.

In bluffs along the Nasel River, section 1, 41/2 miles east of Nasel; upper Oligocene series, Blakeley horizon (Acila gettysburgensis zone of C. E. Weaver); one specimen.

Sandstones in shales in bluffs along the Columbia River at Knappton Mill; upper Oligocene series, Blakeley horizon (Acila gettysburgensis zone of C. E. Weaver) ; associated with Limnopsis, species, and Phacoides columbianum Clark and Arnold; one specimen.

Cementville, across the Columbia River from Astoria, Oregon; three specimens.

OREGON

Astoria (?), Clatsop County; one specimen.

Newport, Yaquina Bay, Lincoln County; three specimens (one is holotype), Cat. No. 353396, U.S.N.M.

Yaquina, Lincoln County; eight specimens, two impressions.

Yaquina, probably; 21 specimens. 
Rocky Point, 4 miles east of the town of Yaquina; it is in a railroad cut a few feet west of bridge No. $9 ; 56$ specimens.

Sandy shale cut along the Corvallis and Eastern Railway between Rocky Point and Oysterville, Yaquina Bay; 14 specimens.

Elk City, Lincoln County; one specimen.

Near Pioneer Quarry near Elk City; two specimens.

One mile south of Springfield Junction, Lane County; one impression, Cat. No. 353397, U.S.N.M.

One mile west of Springfield Junction; one small specimen in a rodule showing only middle portion of carapace, also impression of same; Cat. No. 353398, U.S.N.M.

\section{ZANTHOPSIS HENDERSONIANUS, new species}

Plate 10, figs. 5 and 6

Description of holotype.-Carapace very convex in both directions especially antero-posteriorly. Branchial region separated by a broad, deep furrow from the cardiac and intestinal regions and by a shallower furrow from the gastric region. Twelve bosses or swellings, for the most part conical, are distributed on the posterior two-thirds of the carapace; four are branchial, two along the postero-lateral border, the posterior of which is elongate-triangular in a longitudinal direction, one is near the inner angle of the region while the fourth is lower and situated further outward and forward; the four remaining elevations are median, one urogastric at the middle or highest point of the carapace, one very low, mesogastric, one very large covering the cardiac region, one low and squarish or transversely oblong covering the intestinal or posterior cardiac region. A broad transverse gutter lies in front of the posterior margin. Hepatic region flat and obliquely deflexed. Gastric region not distinctly subdivided; protogastric lobes convex, mesogastric depressed except for the posterior hump; two small transverse epigastric tubercles (pl. 10, fig. 5).

Orbit small, its inner angle less advanced than the front, its outer angle triangular, acute, and less advanced than the inner angle. Inner lower angle triangular. Antero-lateral margin thick, a small blunt horizontal tooth at lateral angle, and in front of it two slight lobes; between the first of these and the orbital tooth the margin is slightly convex. Postero-lateral margin high without marginal line.

Paratypes.-The carapace of paratypes $a$ and $b$ are only about 28 or $29 \mathrm{~mm}$. wide; the edges are broken. Paratype $a$ shows the teeth of the anterior margin (pl. 10, fig. 6) ; two triangular frontal teeth, tips $2.5 \mathrm{~mm}$. apart, and distant $3 \mathrm{~mm}$. from the tips of the inner orbital teeth. The shape and position of the dorsal bosses are the same as in the holotype. No details of the ventral surface of para- 
type $b$ can be made out except that the abdomen is narrow and the sternum small.

Measurements.-Holotype, width of carapace $43.6 \mathrm{~mm}$., frontoorbital width $23.3 \mathrm{~mm}$., posterior width $11.5 \mathrm{~mm}$., chord of anterolateral margin $18.5 \mathrm{~mm}$., postero-lateral margin $23.2 \mathrm{~mm}$.

Occurrence.-Oregon: 1 mile south of Henderson Station (Springfield Junction), Southern Pacific Railroad, Lane County; 200 or 300 feet above the other specimens; Oligocene series; one specimen of carapace with front and left antero-lateral margin broken away, holotype; Cat. No. 353373, U.S.N.M.

California: Llajas Canyon, Simi Valley; Santa Susana Shales, the basal member of the Meganos Group (according to Dr. Bruce L. Clark) ; middle Eocene; two specimens, one of which is a male, paratypes.

Relations.-This species can not be confused with the much more abundant $Z$. vulgaris, because of the different areolation of the carapace. In vulgaris the posterior branchial region is covered with a large swelling instead of two small separated bosses, the epibranchial region has a long obliquely transverse areole instead of a small round one, the cardiac region has two areoles side by side instead of one median, the hepatic region is convex instead of flat, the mesogastric region is plainly divided from the protogastric.

$Z$. hendersonianus is, however, very closely allied to $Z$. dufourii (Milne Edwards), ${ }^{18}$ from the Eocene of Europe, and yet appears to be specifically distinct. Some of the dorsal bosses are of different character: In dufourii the metabranchial boss is round instead of elongate, the cardiac boss round and circumscribed instead of embracing the whole region, the intestinal boss also round instead of oblong. The tooth at the superior inner angle of the orbit is directed forward or nearly so, instead of obliquely outward with an almost transverse inner margin, as in hendersonianus. The lateral lobes are larger and more prominent.

Z. hendersonianus has also much in common with Zanthopsis gruentensis (Schafhäutl), ${ }^{19}$ but in that species the tooth at the lateral angle of the carapace is in a transverse line with the anterior of the metabranchial lobes and the median gastric lobes are broad and partially subdivided by a longitudinal furrow.

\section{ZANTHOPSIS STERNBERGI, new species}

Plate 39

Description of holotype.-A right cheliped in a curved position. Merus, carpus and manus very wide (or high) in proportion to

${ }^{18}$ A. Milne Edwards, Ann. Sci. Nat., ser. 4, Zool., vol. 20, 1863, p. 309, pl. 6.

${ }^{19}$ Süd-Bayerns Lethaea Geognostica, Leipzig, 1863, p. 228, pl. 61, fig. $4 a-c$. 
length. Outer surface of merus finely punctate, a deep gutter running near and parallel to distal margin; on upper margin on posterior border of gutter, a short blunt tooth (pl. 39, fig. 2); on lower margin two stout teeth near together, the one close to gutter is conical; further back on margin, not far from proximal end is a scar which appears to be a eross section of another spine. Upper surface of carpus finely granulate, spine at inner angle short, stout, blunt, recurved; outer surface with four, possibly five, rows of large tubercles, four tubercles in each of the three upper rows. Only three smaller tubercles are visible in the fourth row at the proximal end; a break in the shell obscures the remainder, also a possible fifth row. There is a trace of a distal gutter; there is also a shallow longitudinal depression separating the second from the third row of tubercles. Manus thick, outer surface very convex from end to end as well as from top to bottom. On the short upper margin there is a line of three or four tubercles; on proximal half of outer surface five tubercles forming a $V$ the arms of which diverge widely from the apex situated low down near carpus; a row of five tubercles on proximal three-fifths of lower margin. Distal margin of manus oblique. Fingers thick but rather narrow, widely gaping; tips broken off, that of the dactylus indicated by the corresponding depression; propodal finger horizontal.

Measurements.-Merus, length through middle $16 \mathrm{~mm}$., distal width $15.1 \mathrm{~mm}$. Carpus, superior length $16.6 \mathrm{~mm}$., width measured just behind inner spine $14.2 \mathrm{~mm}$. Manus, length from just above immovable finger to lower proximal angle $24 \mathrm{~mm}$., horizontal length through middle $19.4 \mathrm{~mm}$., superior length $11.9 \mathrm{~mm}$., width (or height) $20.2 \mathrm{~mm}$. Dactylus, length $22 \mathrm{~mm}$., greatest or proximal height $8 \mathrm{~mm}$. Immovable finger, height at its origin about $6 \mathrm{~mm}$.

Occurrence.-California: Kellys Ranch, 5 miles north of Carlsbad Station, Santa Fe Railway, San Diego County; Cretaceous. Holotype, Cat. No. 73390, U.S.N.M.

Relation.-While this cheliped has the general form of a Zanthopsis, it differs from all other species of which the cheliped is known by the greater number and different disposition of tubercles.

\section{Genus LOPHOPANOPEUS Rathbun}

Lophopanopeus Rathbun, Bull. Labor. Nat. Hist. State Univ. Iowa, vol. 4, 1898, p. 272 ; type, L. bellus (Stimpson).

Carapace hexagonal; fronto-orbital border half or more than half greatest width of carapace; front short, divided into two sinuous lobes; postorbital tooth small, more or less coalesced with the next tooth; remainder of antero-lateral margin more longitudinal, cut into three prominent teeth. Palm short, swollen; immovable finger short, rapidly tapering, dactylus narrower and longer, both fingers pointed. Ambulatory legs more or less cristate. 
Oligocene; Pleistocene; Recent. Not before found fossil.

The genus Lophopanopeus is represented on the coast of California by six Recent species, five of which occur south of Monterey Bay. In the Pleistocene in the neighborhood of San Pedro have been found numerous fragments, chiefly fingers, sometimes attached to a manus which is infrequently accompanied by a carpus. An examination of the fingers of Recent species discloses a strong resemblance between fingers of different species, especially between those of bellus and diegensis, of leucomanus and heathii, and of frontalis and lockingtoni. There is on the other hand considerable variation among individuals of a single species from one place. This makes identification of detached fingers difficult and more or less uncertain. The wrists, three in number, are unmistakably $L$. diegensis, and the 13 palms are also referable to the same species. The numerous fingers represent at least three species, which I take to be diegensis, leucomanus, and lockingtoni.

\section{LOPHOPANOPEUS DIEGENSIS Rathbun}

Lophopanopeus diegensis RAthBUn, Amer. Nat., vol. 34, 1900, p. 137.Schмттт, Univ. California Publ. Zoöl, vol. 23, 1921, p. 245, pl. 37, fig. 5, and synonymy.-T. S. OLdroyd, Proc. U. S. Nat. Mus., vol. 65, art. 22,1924 , p. 23.

Occurrence.-California; Pleistocene series:

Rincon del Potrero, Santa Monica; two right movable fingers; Cat. No. 353877, U.S.N.M.

Nob Hill (lumber yard), northeast of San Pedro; lower San Pedro formation; many (about 200) specimens of fingers, major and minor, movable and immovable, besides five palms and two wrists; Cat. Nos. 353367 and 353368, U.S.N.M.

San Pedro; four movable fingers.

Deadman Island, southeast of San Pedro; more than 25 fingers, 8 palms and 1 wrist.

Signal Hill (or Los Cerritos), northeast of Long Beach; Upper San Pedro formation; one major movable finger.

Some fingers are larger than any taken from the sea and indicate that the species was as large as $L$. bellus, which ranges from Monterey Bay northward.

Range of Recent L. diegensis.-From Monterey Bay to San Diego Bay.

\section{LOPHOPANOPEUS LEUCOMANUS (Lockington)}

Xanthodes leucomanus Lockington, Proc. California Acad. Sci., vol. 7, 1876 (1877), p. 32 (not leucomanus, p. 100).

Lophopanopeus leucomanus Scнмгтт, Univ. California Publ. Zoöl., vol. 23, 1921 , p. 243 , pl. 37 , fig. 6 , text-fig. 145 , and synonymy.-T. S. OLdroyd, Proc. U. S. Nat. Mus., vol. 65, art. 22, 1924, p. 23. 
Occurrence.-California; Pleistocene series:

Nob Hill (lumber yard), northeast of San Pedro; lower San Pedro formation; over 100 movable and 1 immovable finger; Cat. Nos. 353365 and 353366, U.S.N.M.

San Pedro; four movable fingers.

Deadman Island, southeast of San Pedro; 17 movable fingers. Signal Hill (or Los Cerritos), northeast of Long Beach; upper San Pedro formation; two movable fingers, major and minor.

Range of Recent specimens.-From Monterey to San Diego.

$L$. heathii has similar fingers to those of $L$. leucomanus, and it is possible that it is included among the fingers above listed. L. leucomanus is of more frequent occurrence to-day than heathii and especially in the neighborhood of San Pedro. The two species may have had a common origin in the Pleistocene.

\section{LOPHOPANOPEUS LOCKINGTONI Rathbun}

Xanthodes leucomanus Lockington, Proc. California Acad. Sci., vol. 7, 1876 (1877), p. 100 (not leucomanus, p. 32 ).

Lophopanopeus lockingtoni Schмгт, Univ. California Publ. Zoöl., vol. 23, 1921, p. 244, pl. 37, fig. 2.-T. S. Oldroyd, Proc. U. S. Nat. Mus., vol. 65, art. 22, 1924, p. 23.

Occurrence.-California: Nob Hill (lumber yard), northeast of San Pedro; lower San Pedro formation, Pleistocene series; nine major movable fingers; Cat. No. 353376, U.S.N.M. As in L. diegensis, some of the fossil fingers are indicative of much larger specimens than have yet been reported among Recent material.

Range of Recent specimens.-From San Pedro to San Diego, California; Gulf of California (Lockington).

LOPHOPANOPEUS OLEARIS, rew species

Plate 11, fig. 4

Description.-Carapace well areolated, the gastric and its subregions, the hepatic and the branchial regions strongly marked; mesogastric region small, narrow part slightly constricted near the base, anteriorly acute; epigastric and protogastric lobes raised. Still more prominent is the ridge which is parallel to the coalesced anterolateral tooth and divides the hepatic region into two almost equal parts. The posterior half of the branchial region is dorsally swollen forming a circular smoothly rounded boss. Between the branchial and the cardiac-intestinal region there is a narrow and obliquely longitudinal ridge.

The two sides of the frontal margin are a little oblique to each other; there is a large median pit near the edge but no emargination is apparent. A depression on the dorsum between front and 
orbit. Orbital margin crenulate; orbit small, as customary in the genus. Antero-lateral border inclined upward. The ends of all the lateral teeth are broken; the first tooth or orbital angle is not prominent and is fused with the second which is probably a shallow lobe; the third, fourth, and fifth are subequal. Postero-lateral margins a little longer than antero-lateral, convergent; posterior margin sinuous.

The carpus of the cheliped has a deep groove across the distal end; the inner tooth is short.

Measurements.-Holotype, length of carapace $20.5 \mathrm{~mm}$., width at sinus in front of last lateral tooth $24.7 \mathrm{~mm}$., fronto-orbital width 17 $\mathrm{mm}$., width of front $9.1 \mathrm{~mm}$.

Occurrence.-Alaska: Just below the lower seepage on Pearl Creek, on Pearl Creek oil claim No. 11; Nichowak District; Oligocene series; carapace and carpus of left cheliped of one specimen. Type in University of California.

Relation.-This species has much in common with $L$. bellus, ${ }^{20}$ a species now living on the Pacific coast from Prince William Sound, Alaska, to Long Beach, California. Its narrow part of the mesogastric region is not constricted but tapers gradually to a point, the hepatic ridge is less pronounced and the branchial region is flat where in the other it is symmetrically swollen.

\section{Genus CYCLOXANTHOPS Rathbun}

Cycloxanthops Rathbun, Proc. Biol. Soc. Washington, vol. 11, 1897, p. 164; type, C. sexdecimdentatus Milne Edwards and Lucas.

Carapace broad, antero-lateral borders very long; front horizontal, prominent, divided into two lamellar lobes; orbits small, external angles inconspicuous. Palms elongate, fingers stout, tapering to a point.

Pleistocene; Recent. Not before found fossil.

CYCLOXANTHOPS NOVEMDENTATUS (Lokington)

Plate 1, figs. 15 and 16

Xanthodes? novemdentatus Lockington, Proc. California Acad. Sci., vol. 7, 1876 (1877), p. 32.

Cycloxanthops novemdentatus ScHмrтt, Univ. California Publ. Zoöl., vol. 23 , 1921 , p. 239 , pl. 37 , fig. 7 , text-fig. 142 , and synonymy.

Occurrence.-California: Rincon del Potrero, Santa Monica; Pleistocene; 29 movable (pl. 1, fig. 15), 13 immovable fingers (pl. 1, fig. 16); Cat. No. 353371, U.S.N.M.

${ }^{20}$ Xantho bella Stimmson, Ann. Lyc. Nat. Hist. New York, vol. 7, 1860, p. 204, pl. 5, fig. 2 . 
Range of Recent specimens.-From Monterey Bay, California, to Guadalupe Island, Mexico.

\section{Family CANCRIDAE Alcock}

Carapace broadly oval, front with several teeth, one of which is median. Antennules fold back longitudinally. Antennal flagella usually short and more or less hairy. Third maxillipeds overlapping endostome.

\section{Genus CANCER Linnaeus}

Cancer Linnaeus, Syst. Nat., ed. 10, vol. 1, 1758, p. 625; type, C. pagurus Linnaeus.

Carapace transverse, subelliptical, often indistinctly areolated; front narrow, cut into five teeth or lobes. Orbits small, with two fissures in both upper and lower margins. Antennal fiagellum excluded from orbit. Palms longitudinally ridged outside; fingers broad at attachment, tapering to a point; dactyli thick above, upper surface gradually rounding into outer surface, upper edge sometimes cristate.

Eocene; Recent.

CANCER GABBI, new species

Plate 16, figs. 7 and 8

Among the specimens borrowed from the Academy of Natural Sciences, Philadelphia, under the name of Callianassa stimpsonii Gabb, are two which are portions of right chelipeds of a Cancer. They were labeled by Gabb, "Martinez or Clayton" and are Eocene.

The more complete though smaller specimen (holotype) shows the outer face of the palm and a portion of the outer face of the wrist against which it is flexed (pl. 16, fig. 7). The larger specimen (paratype) is more fully free from the matrix and comprises the distal portion of a palm, both sides of which are exposed (pl. 16, fig. 8).

Description of palm.--Lower margin more arcuate than the upper, the deepest part of the curve being nearer the distal than the proximal end. Base of fixed finger horizontal. Greater part of upper margin a shallow arch, the distal end is separately ascending. Proximal margin very oblique. Outer layer of shell lacking; exposed surface covered chiefly with raised reticulating lines; four smooth longitudinal stripes are visible, one on upper surface, one immediately above lower margin, both wide, a narrower stripe at middle of outer surface and a very narrow one a little below the middle. The bases of both fingers are wide so that the intervening gape is relatively narrow; the movable is a little wider than the immovable. finger. 
Measurements.-Smaller palm, superior length $12.6 \mathrm{~mm}$., greatest height $13.5 \mathrm{~mm}$., inferior length to a point below sinus between fingers $18 \mathrm{~mm}$. Larger palm, height of cross section behind middle 13 $\mathrm{mm}$., width of same $8.5 \mathrm{~mm}$.

\section{CANCER BAINBRIDGENSIS, new species}

Plate 16, figs. 2 and 3

Description.-The surface of both fingers is covered with coarse, prominent, separated tubercles. The holotype (pl. 16, fig. 2) has a broad and nearly level upper surface rounding into the lateral surfaces. Outer surface with a shallow longitudinal furrow. Basal prehensile tooth proportionally smaller than that of the paratype. Cross section of finger just distad to basal tooth almost circular. The lower part of the paratype is broken away. Viewed from above the prehensile tubercles form a row through the middle; basal tubercles isolated and much the largest, in cross section squarish with corners rounded off; the other three tubercles are contiguous and diminish gradually in size (pl. 16, fig. 3 ).

Measurements.-Greatest width of dactylus (holotype) $11.5 \mathrm{~mm}$., height from middle of lower surface of basal tooth $14 \mathrm{~mm}$., height at insertion in propodus $25.6 \mathrm{~mm}$. Width of lower surface of immovable finger below middle of basal tooth, approximately (at least) $13.3 \mathrm{~mm}$.

Occurrence.-Washington: Sandstone beach at Bean Point, Bainbridge Island, Puget Sound; upper Oligocene; piece of a right movable finger (holotype) and of a right (?) immovable finger (paratype). Holotype in Stanford University.

Relation.-Differs from other species in the broad and slightly oblique upper surface of the dactylus or movable finger, but approaches that of $C$. productus.

\section{CANCER FISSUS Rathbun}

Plate 6 , fig. 1 ; plate 16 , figs. 5 and 6

Cancer fissus Rathbun, Proc. U. S. Nat. Mus., vol. 35, 1908, p. 343, pl. 49, fig. 1; type-locality, near Henry Spring on east face of " 1900 foot hill" 4 miles south of Coalinga, Fresno County, California; toward base of Etchegoin formation, Pliocene [not Miocene] series; holotype, No. 165477 , U.S.N.M.

Described from a carapace only (pl. 6, fig. 1). Lateral teeth subtruncate, separated from one another by shallow $\mathrm{V}$-shaped notches and long closed fissures; teeth eight, including tooth at outer angle of orbit, irregular in size and shape; the first, third, fifth, and seventh larger than intervening teeth, ninth tooth very narrow; the 
fifth, sixth, seventh, and eighth teeth have each a small horny point at their anterior angle.

Additional occurrence.-Two incomplete left palms from the same region as the type-locality of $C$. fissus are placed here tentatively. They are from the south central part of the southeast quarter of section 24, Coalinga Quadrangle, California; Etchegoin formation, Pliocene series.

Measurements of larger palm.-Height $24 \mathrm{~mm}$., length on upper margin $19.8 \mathrm{~mm}$., thickness $15.3 \mathrm{~mm}$.

Description of palm.-Unusually short and high, much swollen; upper edge blunt, without serrations; outer surface showing traces of five longitudinal ridges (pl. 16, fig. 5), as in other species of Cancer. Fingers absent, but the fixed finger is apparently much deflexed; its height at base, measured from lower margin of palm is not more than two-fifths the height of the cavity in which the dactylus once fitted (pl. 16, fig. 6). These two characters distinguish the palm from that of any other Cancer.

\section{CANCER URBANUS Rathbun}

Plate 15 ; plate 16 , fig. 1

Cancer urbanus Rathbun, Proc. U. S. Nat. Mus., rol. 53, 1917, p. 451, pl. 59; type-locality, Los Angeles, California; from foundation of large building; Pliocene series; carapace embedded in blue clay, Cat. No. 324300 , U.S.N.M.

Description.-Surface of carapace (pl. 15) about equally convex from side to side and from front to back; uneven, closely granulate, granules larger and more prominent on the most elevated portions; interregional depressions deep. Antero-lateral teeth 9, including the tooth at lateral angle of carapace and at outer angle of orbit; teeth acute, margins straight, anterior margin usually considerably shorter than posterior margin; margins of seventh or widest tooth nearly equal. Furrows leading back from sinuses of anterior margin deep.

Additional occurrence.-Santa Monica, California, in Rustic Canyon; Pliocene series; portion of right cheliped showing dorsal view of carpus and manus; Cat. No. 353394, U.S.N.M. The specimen is tentatively linked up with this species. A specimen showing both carapace and cheliped is necessary to prove their specific identity.

Measurements.-Estimated width of carapace (holotype) measured between antero-lateral sinuses $48 \mathrm{~mm}$., length of carapace about $34 \mathrm{~mm}$. Length of carpus (Santa Monica) $20.7 \mathrm{~mm}$., superior length of manus $20.4 \mathrm{~mm}$.

Upper surface of carpus (pl. 16, fig. 1) bounded by a band of coarse granules; in the middle two high granulated tubercles are placed transversely and from each an irregular band of granules 
extends proximally. A third large tubercle is situated near articulation with manus. The manus is turned so that the upper margin is directed almost upward. The visible surface is very rough with granules, the margin more coarsely so and armed with two large tubercles; margin highest at its proximal third and lowest at its distal fifth. On the inner surface a little below the margin and slightly distad to the most distal of the marginal tubercles, there is another large tubercle.

The granulation of the cheliped is similar to that of the holotype carapace, which lends credence to the theory that they are conspecific.

\section{CANCER PRODUCTUS Randall}

Cancer productus Randall, Journ. Acad. Nat. Sci. Philadelphia, vol. 8, 1839, p. 116.-Schmitr, Univ. California Publ. Zoöl., vol. 23, 1921, p. 220, text-fig. 136, and synonymy.-T. S. Oldroyd, Proc. U. S. Nat. Mus., vol. 65 , art. 22,1924 , p. 23.

Cancer brewerii GABB, Palaeontology of California, vol. 2, sec. 1, part 1, 1869 , p. 1, pl. 1, fig. 1 (type-locality, near Santa Barbara, Pliocene; type probably not extant).-Cooper, Seventh Ann. Rept. State Mineralogist, 1887 (1888), p. 227 ; "Pl. or Mioc."

Cancer breweri Arnold, Mem. California Acad. Sci., vol. 3, 1903, p. 345; Deadman Island, San Pedro, in Lower San Pedro formation, Pleistocene series.

Gabb compared his species with $C$. magister, instead of $C$. productus with which $C$. brewerii is identical. This determination is confirmed by the examination of a finger of $C$. productus from the Pliocene of Ventura County, recently collected by Louis N. Waterfall.

Occurrence.-Pliocene and Pleistocene series:

CALIFORNIA

Ventura County; Pliocene; 1 left immovable finger of a large specimen.

Following are Pleistocene:

Rincon del Potrero, Santa Monica; 30 specimens of fingers more or less incomplete; Cat. No. 353391, U.S.N.M.

Nob Hill (lumber yard), northeast of San Pedro; lower San Pedro formation; nine movable, three immovable fingers; Cat. No. 353393, U.S.N.M.

San Pedro; Kate Stephens; two movable fingers.

Deadman Island, southeast of San Pedro; four movable and two immovable fingers.

Signal Hill (or Los Cerritos), northeast of Long Beach; Upper San Pedro formation; four movable and one immovable finger; Cat. No. 353390 , U.S.N.M. 
Point Loma, "coal mine," ocean shore of Point; right movable finger and right immovable finger of much larger specimen; Cat. No. 8258 , U.S.N.M.

LOWER CALIFORNIA, MEXico

San Quentin Bay, lava beds; one movable finger; Cat. No. 353392, U.S.N.M.

Range of Recent specimens.-From Kodiak to Magdalena Bay, Lower California.

\section{CANCER BRANNERI, ${ }^{21}$ new species}

Plate 16, fig. 4

Cancer gibbosulus Rathbun, Proc. U. S. Nat. Mus., vol. 21, 1898, p. 581 (part; American specimens), not $C$. gibbosulus (de Haan).-Schмiтt, Univ. California Publ. Zoöl., vol. 23, 1921, p. 226, pl. 36, fig. 7, and synonymy (part; American specimens).

Holotype.-Male, Recent, San Francisco; D. S. Jordan, collector; 1880 ; Cat. No. 3092 , U.S.N.M.

- The acquisition of large and mature Recent specimens of the Japanese Cancer gibbosulus makes it possible to demonstrate that the American form is specifically distinct. The following are the chief differences: The carapace of $C$. branneri is a little wider in proportion to its length, the postero-lateral margins are more concave, the principal (anterior) of the two postero-lateral denticles being sharp-pointed (spiniform) instead of blunt; the antero-lateral teeth always all sharp-pointed, although individuals vary in width and sharpness, whereas in gibbosulus, the first six teeth incline to be blunt; the outer orbital tooth is narrower than in gibbosulus; granules of dorsal surface fewer, larger and more scabrous, areoles lower and flatter, especially the protogastric pair and that at inner angles of branchial region. Sixth abdominal somite narrower, the proximal width exceeding the length but little, whereas in gibbosulus the width is one and one-half times the length; this character is much less marked in small specimens. The dactylus of the cheliped (pl. 16, fig. 4) has on its outer face two strong carinae the upper of which is spinous, and between them a tuberculate carina on the proximal half only; in gibbosulus the intermediate carina is full length and stronger than the lower, which becomes weaker proximally, as does the upper carina which is spinulous but without the single row of strong spines seen in branneri.

Occurrence of fossils.-California; Pleistocene series:

San Pedro; two movable and one immovable finger; Cat. No. 353381, U.S.N.M.

${ }^{21}$ For the late Dr. John Casper Branner, geologist and president of Stanford University. 
Deadman Island, southeast of San Pedro; two movable fingers. Signal Hill (or Los Cerritos), northeast of Long Beach; upper San Pedro formation; one movable finger; Cat. No. 353594, U.S. N.M. This finger belonged to a larger specimen than has been recorded for Recent occurrences.

Range of Recent specimens.-From Granite Cove, Port Althorp, Alaska, to Santa Catalina Island.

\section{CANCER ANTHONYI Rathbun}

Cancer anthonyi Rathbun, Proc. Biol. Soc. Washington, vol. 11, 1897, p. 111.-Sснмттт, Univ. California Publ. Zoöl., vol. 23, 1921, p. 227, pl. 35, fig. 1, and synonymy.

Occurrence.-Spanish Bight, San Diego Bay, California; Pleistocene series; eight movable and two immovable fingers; Cat. No. 353380 , U.S.N.M.

Rainge of Recent specimens.-From Long Beach, California, to Playa Maria Bay, Lower California.

\section{CANCER JORDANI Rathbun}

Cancer jordani Rathbun, Amer. Nat., vol. 34, 1900, p. 133.-Schмitт, Univ. California Publ. Zoöl., vol. 23, 1921, p. 228, pl. 36, figs. 5 and 6, and synonymy.

Occurrence.-California; Pleistocene series:

Rincon del Potrero, Santa Monica; 2 movable fingers; Cat. No. 353386, U.S.N.M.

Nob Hill (lumber yard), northeast of San Pedro; Lower San Pedro formation; 22 movable, 5 immovable fingers; Cat. Nos. 353385 and 353388 , U.S.N.M. These fingers are of unusual size indicating that the species was much larger in the Pleistocene than now.

San Pedro; one movable finger.

Deadman Island, southeast of San Pedro; 13 movable fingers, 1 immovable finger; Cat. No. 353387, U.S.N.M.

Spanish Bight, San Diego Bay; three movable fingers.

Range of Recent specimens.-From Half Moon Bay, California, to San Geronimo Island, Lower California.

\section{CANCER MAGISTER Dana}

Cancer magister Dana, Proc. Acad. Nat. Sci. Philadelphia, vol. 6, 1852, p. 73.-Sснмптт, Univ. California Publ. Zoöl., vol. 23, 1921, p. 229, text-fig. 138, and synonymy.

Occurrence.-Nob Hill (lumber yard), northeast of San Pedro, California; lower San Pedro formation, Pleistocene series; two immovable fingers; Cat. No. 353389, U.S.N.M. 
Range of Recent specimens.-From Unalaska to Magdalena Bay, Lower California.

\section{CANCER GRACILIS Dana}

Cancer gracilis DANa, Proc. Acad. Nat. Sci. Philadelphia, vol. 6, 1852, p. 73.-Sснмiтt, Univ. California Publ. Zoöl., vol. 23, 1921, p. 232, pl. 35, fig. 2, and synonymy.-T. S. Oldroyd, Proc. U. S. Nat. Mus., vol. 65 , art. 22,1924, p. 23.

Occurrence.-California; Pleistocene series:

Rincon del Potrero, Santa Monica; seven movable and six immovable fingers; Cat. No. 353382, U.S.N.M.

Nob Hill (lumber yard), northeast of San Pedro; Lower San Pedro formation; 2 movable fingers; Cat. No. 353384, U. S. N. M.

Deadman Island, southeast of San Pedro; three movable and one immovable finger.

Spanish Bight, San Diego Bay; four movable and five immovable fingers; Cat. No. 353383, U.S.N.M. San Diego Society of Natural History; two movable and one immovable finger.

Range of Recent specimens.-From Kasaan Bay, Prince of Wales Island, Alaska, to Playa Maria Bay, Lower California.

\section{Genus BRANCHIOLAMBRUS Rathbun}

Branchiolambrus Rathbun, Proc. U. S. Nat. Mus., vol. 35, 1908, p. 344 ; type, B. altus Rathbun.

Carapace rhomboidal, its anterior two-thirds subtriangular; orbits directed outward. Branchial regions nearly touching on median line. Front and antero-lateral margins dentate; postero-lateral margin a sinuous line, below which the surface is steeply inclined.

Miocene.

\section{BRANCHIOLAMBRUS ALTUS Rathbun}

Plate 4, figs. 2 and 3

Branchiolambrus altus RAthbun, Proc. U. S. Nat. Mus., vol. 35, 1908, p. 345, pl. 47, figs. 2 and 3 ; type-locality, Wagon Wheel Mountain, southeast quarter, section 36, township 25 south, range 18 east, Devil's Den District, about 36 miles south of Coalinga, Kern County, California; lower Miocene series, immediately below Vaqueros beds; one carapace, Cat. No. 165478, U.S.N.M.

Description.-Carapace rhomboidal (pl. 4, fig. 2), front subtriangular, antero-lateral margin slightly arcuate, postero-lateral margin equally long, sinuous; below it a vertically oblique facet. Carapace very convex at its widest part (pl. 4, fig. 3), branchial regions nearly touching each other, an acute, conical tubercle at inner angle of each. Surface crisply granulate. Cervical suture shallow anteriorly, deep and narrow posteriorly. Cardiac region 
narrow, depressed, occupied by two tubercles side by side. Frontal teeth subequal, broad and blunt. Inner orbital tooth acute; width of orbit equal to sinus directly in front of it. Antero-lateral margin incomplete, bearing at least nine teeth. One rudimentary postero-lateral tooth.

Measurements.-Length (approximate) of carapace $18.2 \mathrm{~mm}$., width (approximate) $27.2 \mathrm{~mm}$., height at least $5 \mathrm{~mm}$.

Relation.-In the convexity of the carapace and the proximity of the branchial regions this species resembles the recent $C$ ancer longipes $^{22}$ (Panama to Chile). The subpostero-lateral area and the composition of the front are also akin to those of the genus $C$ ancer. The genus Branchiolambrus is therefore placed in the Family Cancridae instead of the Parthenopidae as heretofore. It differs from Cancer in the triangular shape of the anterior two-thirds of the carapace and the outwardly directed orbits.

\section{Family PORTUNIDAE Dana}

Carapace moderately transverse, usually widest at last anterolateral marginal tooth; front with or without median tooth. Antennules fold back transversely or obliquely. Third maxillipeds not overlapping endostome. Ambulatory legs flattened and more or less distinctly adapted for swimming.

\section{Genus CARCINIDES Rathbun}

Carcinides Rathbun, Proc. Biol. Soc. Washington, vol. 11, 1897, p. 164; type, C. maenas (Linnaeus).

Carapace not broad, subhexagonal, no distinct transverse ridges; antero-lateral borders cut into five teeth. Front slightly projecting, three-lobed. Chelipeds massive; arm short, unarmed; inner angle of wrist spiniform; no spines nor costae on hand; fingers stout, not strongly toothed.

Cretaceous; Eocene; Recent.

CARCINIDES MINOR, new species

Plate 16, figs. 9 and 10

Description of holotype.-Carapace with a quinquedentate anterolateral margin (pl. 16, fig. 9), the convex outer edges of the teeth forming a regular arch, their inner edges nearly straight, tips acute, first or orbital tooth smaller than second, fifth small and less projecting laterally than the fourth, which marks the widest part of the carapace. Two slight fissures in upper border of orbit; fronto-

${ }^{2}$ Bell, Proc. Zoöl. Soc. London, vol. 3, 1835 (1836), p. 87; Trans. Zoöl. Soc. London, vol. 1,1836 , p. 337 , pl. 43. 
orbital angle broadly rounded; front slightly more advanced at middle than at ends, edge not fully made out. Postero-lateral margin sinuous, marked by a line of granules.

Of the regions the mesogastric is very well marked except posteriorly; from it a median furrow extends to the margin of the front. A deeper furrow runs obliquely inward from the edge of the inner orbital angle; from its inner end a broad, shallow depression makes an oblique arch to the fourth lateral tooth; cervical furrow also shallow. One small inner branchial lobule. Along the postero-lateral margin the surface falls rather steeply. The surface is granulate on the elevations; the granules are coarser on a broad transverse curve (convex forward) across the branchial region from the widest part of the mesogastric region to the last lateral tooth; and also on two shorter and broader curves just before the middle of each protogastric lobe.

Measurements.-Holotype, length of carapace $7.8 \mathrm{~mm}$., greatest width $10.7 \mathrm{~mm}$., fronto-orbital width $6.6 \mathrm{~mm}$., frontal width $2.8 \mathrm{~mm}$.

Occurrence.-Washington: Railroad bluff about $1 \frac{1}{2}$ miles south of Vader, Lewis County, about 700 feet below railroad post No. 79, section 4, township 11 north, range 2 west; Eocene series; one small carapace, holotype, and a right wrist of a larger specimen which may belong to the same species. Holotype in University of Washington.

Relation.-Compared to young $C$. maenas (Linnaeus), the antero-lateral teeth are separated by narrower sinuses, there are two slight transverse dorsal ridges, not developed in maenas, the postero-lateral margins though equally convergent are sinuous instead of straight. On the other hand, in both species the lateral teeth are of similar shape and relative size, viz, the first smaller than the second, the last narrow, reduced. The furrow at the inner orbital angle is common to both, and the corresponding elevation of the adjacent orbital region. The median furrow is a little deeper in the fossil and the inner branchial lobulation simpler than in maenas.

Wrist.-The specimen of wrist (pl. 16, fig. 10) occurring in the same deposit as the type is very likely from a larger specimen of this species. The article has the same general shape and inequalities of surface as in $C$. maenas including a broad depression around the inner border and a corresponding elevation adjacent. The dorsal aspect is wider in relation to the length than in maenas, and the inner spine is elongate conical, narrower than in maenas and less prismatic; the spine is finely granulate but most of the outer layer which remains is much worn. Until a wrist is found attached to the body, its identity can not be fully established. 
Doubtful occurrence.-California: $21 / 2$ miles south of mouth of Soledad Valley in the sea cliff. On the La Jolla topographic sheet, due west of half way between the " $p$ " and " $u$ " in Pueblo (south of mouth of Soledad Valley) in sea cliff facing ocean. Eocene series. A carapace slightly larger than the type is embedded in friable rock; it is referred with much uncertainty to $C$. minor, as very few details can be made out.

\section{Genus PORTUNITES Bell}

Portunites Bell, Monog. Fossil Malac. Crust. Great Britain, 1857, p. 20; type, $P$. incerta Bell.

Carapace little broader than long, depressed; front dentate; orbits large; antero-lateral margin four or five toothed, posterior tooth longer; branchial region with a blunt longitudinal ridge, against which the last leg lies when raised above the carapace. Chelipeds stout, of moderate length. Ambulatory legs slender, not natatory.

Eocene; Oligocene.

KEY TO THE PACIFIC SLOPE SPECIES OF THE GENUS PORTUNITES

$\mathrm{A}^{1}$. Carapace wide; width, measured in front of spine at lateral angle, one and one-half times length. Orbit deep; length of outer orbital tooth on its inner slope as great as its basal width__________alaskensis, p. 72 .

$\mathrm{A}^{2}$. Carapace narrower; width, measured in front of spine at lateral angle, one and one-third times length.

$\mathbf{B}^{1}$. Regions of carapace deeply separated. Gastric region deeply divided into three subregions. No very prominent tubercles near inner angle of branchial region. Size small insculpta, p. 71 .

$\mathrm{B}^{2}$. Regions not deeply separated except at middle of carapace. Two very high tubercles in an obliquely longitudinal line near inner angle of branchial region. Size larger triangulum, p. 68.

PORTUNITES TRIANGULUM, new species

Plate 17 , figs. 3-6

Description.-Outlines of carapace (pl. 17, fig. 5): The latera! spine is located opposite the widest part of the mesogastric region; it curves forward and upward, is acuminate and less than an eighth as long as the width of the carapace at the sinus. Between the spine and the orbital tooth there are three triangular acute teeth; the second is acuminate and longer than the first, and the third, next the lateral spine, is stouter than the others. The orbit is equal in width to half the interorbital distance, its upper margin is crenulate, interrupted by two fissures, the intervening margin truncate; its inner angle is a short, acute tooth. The front proper is four-toothed, a little advanced beyond the orbital angles, teeth acute, middle pair slightly more produced than the outer pair, interspaces broadly $\mathrm{U}$-shaped, the median sinus narrower than the submedian. Pos- 
tero-lateral margin sinuous both in dorsal and in lateral view, and marked by a granulate line for about two-thirds the distance from the lateral spine. Posterior margin sinuous, slightly concave at middle and having a continuous raised line of granules.

Areolation of carapace: The mesogastric and cardiac regions are well delineated, the hepatic region depressed; anterior end of mesogastric region a little raised. A blunt, branchial ridge runs inward and slightly forward from the lateral spine and bends gradually backward to a point just behind the broadest part of the mesogastric region where it forms a large tubercle. This tubercle is one of three making an almost equilateral triangle, ${ }^{23}$ the second tubercle situated at the inner branchial angle, and the third in an almost transverse line with the second but a little farther forward; it is more acute than the others, almost sharp to the touch and has a long posterior slope; the innermost tubercle is less elevated than the others. The cardiac region has a low elevation each side of the middle. Elevations of carapace granulated. In front of branchial ridge a subparallel row of about six low tubercles.

Orbits and ventral aspect: The orbit is deep and high in proportion to its width, the eye does not fill it; lower margin more advanced than upper, denticulate, spine at inner angle very stout. Ischium of outer maxilliped (pl. 17, fig. 6) suboblong, divided into two unequal parts by a very deep, sinuous groove, which anteriorly approaches the inner margin. Surface of merus very uneven. Exognath about half as wide as endognath. Abdomen of male triangular from the third segment to the tip; third to fifth segments fused; the third and fourth together are depressed in the middle and on either side form a smooth, rounded elevation; sixth segment twice as wide at base as its greatest length; terminal segment subtriangular, broader than long. The surface of the abdomen appears almost smooth, the lower surface of the carapace, the sternum, maxillipeds and beginning segments of the chelipeds are more or less finely granulate. The small peg on the second sternal segment which serves to hold the abdomen in place, is visible on the right side of one male and is very sharp. In only one specimen is any portion of a female abdomen visible, and there only two segments, perhaps the fifth and sixth; the fifth (if such it be) is shorter and has more arcuate outer margins than the sixth.

Chelipeds and legs: Chelipeds unequal, stout, granulate; merus with a subdistal groove above; carpus uneven, with a strong inner spine. Manus swollen, a low, longitudinal ridge through the middle of the outer surface (pl. 17, fig. 3), the ridge gradually flattening out toward the fingers; granulation fine and on either side of the ridge reticulated; upper surface (pl. 17, fig. 4) flat or slightly con- 
cave, making a blunt angle with the outer surface; both inner and outer ridges show a faint tuberculation. Fingers long and narrow, -suboval in section, prehensile edges armed with many small, unequal teeth; fingers more widely separated in major than in minor chela on account of the greater height of the hand, the fingers being of approximately the same width in both chelae.

Ambulatory legs: The merus joints of the three ambulatory legs are long and narrow, oval in cross-section. There is no trace of the last pair of legs.

Measurements.-Male holotype, length of carapace on median line $31 \mathrm{~mm}$., width at sinus in front of lateral spine $42.5 \mathrm{~mm}$., frontoorbital width about $24 \mathrm{~mm}$. The following measures are approxi. mate: Length of carapace of female, No. 193, on median line 18.7 $\mathrm{mm}$.; width at sinus in front of lateral spine $25 \mathrm{~mm}$. Width at same sinus of male from Porter, H. Landes, collector, $33.6 \mathrm{~mm}$.; of specimen, N. Pac. 53, $33.2 \mathrm{~mm}$.; of a male from same lot $47 \mathrm{~mm}$., its length $33.2 \mathrm{~mm}$.; while a major manus, N. Pac. 211, belongs to a considerably larger carapace than any preserved, having a maximum height of $20 \mathrm{~mm}$., thickness $14.3 \mathrm{~mm}$. and a superior length of at least $20 \mathrm{~mm}$.

Occurrence.-

WASHINGTON

In bluffs immediately north and south of Porter, Chehalis County; Oligocene series; one female.

Porter, Chehalis County; middle Oligocene series; two specimens. Shaly sandstone bluff on Chehalis River, below Porter; middle Oligocene series; three specimens.

Bluff one-half mile east of Porter Station, Grays Harbor County; middle Oligocene series; one specimen having only the chelipeds exposed.

One and a half to two miles northwest of Galvin; middle Oligocene; one specimen and impression.

Sandy shale bluffs along the Chehalis River, northwest of mouth of Lincoln Creek, Lincoln Creek; middle Oligocene series; a large right manus.

Near junction of Lincoln Creek and Chehalis River some 5 (?) miles northwest of Centralia; Lincoln beds, Oligocene series; one male, holotype, Cat. No. 353567, U.S.N.M.

OREGON

Nehalem River, ford north of Mishawaka, Clatsop County: Oligocene series; one right chela ; Cat. No. 166468, U.S.N.M.

Sandy shale cut along the Corvallis and Eastern Railway between Rock Point and Oysterville, Yaquina Bay; Oligocene series; one carapace and portions of a major and a minor cheliped. 
Rocky Point, 4 miles east of Yaquina City; Oligocene series; one specimen.

Probably near Yaquina; Oligocene series; one specimen embedded in nodule.

PORTUNITES INSCULPTA, new species

Plate 17 , figs. 1 and 2

Description.-The dentate margins are considerably obscured in the one specimen, holotype, in which they are at all visible (pl. 17 . fig. 2). The lateral teeth are five in number, the one at the lateral angle having an indication, by a cross-section shown on the right side of the impression, of a stronger tooth or spine than the others: the penult tooth is acute and hooked forward, having a convex posterior and a concave anterior margin; the first two teeth, that is the one at the orbital angle and the next one appear to be narrower than the others. The tips of the frontal teeth of the middle pair are about $1 \mathrm{~mm}$. apart. A median furrow extends from the margin to the mesogastric region. The areolations of the carapace are very prominent; the furrows about the cardiac and mesogastric regions are notably deep; that separating those two regions from each other is less deep as is also the groove either side of the stalk of the mesogastric spatula. The blade of the spatula is raised above the stalk and is a little longer. Cardiac region cordate, narrow behind, its anterior transverse elevation being partially divided by a small anterior median depression. At the branchial angle between gastric and cardiac regions there is a large, somewhat pointed tubercle or boss. From it and separated by a shallow groove, begins the epibranchial ridge which arches forward and continues to the lateral spine; metabranchial region high, forming a sort of ridge which parallels the curve of the cardiac region and is separated anteriorly by a slight furrow from the beginning of the epibranchial ridge; the metabranchial ridge is accented inwardly by the deep trench bordering the cardiac region, but outwardly it slopes gradually downward and outward toward the postero-lateral margin. Both epibranchial and metabranchial ridges form a boss at their inner extremities. Hepatic region depressed. The elevated portions of the carapace are granulate, coarsely so on the highest parts, the depressions are smooth.

The outer face of the chela (right major) is exposed (pl. 17, fig. 1); lower margin sinuous. The palm is scarcely longer than its greatest, or distal, height; it is much swollen especially in vertical direction, and is covered with short transverse lines of punctae, but these do not perhaps represent the outer surface; the upper margin is almost straight, the supero-distal angle is produced and appears to be considerably above the dactylus. The fingers are about as long as 
palm (their tips are absent), they are equally broad at base leaving a moderate gape and taper gradually toward the extremity. The dactylus has a long, stout, backward-pointing tooth at its base; three other teeth are visible on the prehensile edge, they are short, blunt and near together. The propodal finger is slightly deflected.

Measurements (approximate).-Holotype, length of carapace 12 $\mathrm{mm}$., width at sinus in front of lateral spine $15.8 \mathrm{~mm}$.

Occurrence.-Oregon: Basket Point, Umpqua River, about 12 miles below mouth of Calapooia River; middle Eocene series; one holotype and impression and two paratypes, each represented by the dorsal surface of the carapace in a small nodule; Cat. No. 353347, U.S.N.M. Also from the same locality a small major chela in a nodule which is referred to this species because the palm is of similar character to that of the nearly related species, $P$. triangulum.

Relation.-Nearly related to the type species of the genus, $P$. incerta Bell ${ }^{24}$ from the Eocene of the Isle of Sheppey, England. in $P$. incerta the narrow part of the mesogastric region is not spatuliform, the metabranchial ridge is straight and not bounded outwardly by a furrow, and the inner extremity of the branchial ridges forms a more pronounced tubercle.

From $P$. triangulum, this species may be distinguished by the broader mesogastric region, the more prominent protogastric lobes, the deeper groove about the cardiac region. $P$. triangulum has a triangle of three tubercles at the inner angle of the branchial region, while in $P$. insculpta this arrangement is so obscurely indicated as not to be noticeable.

\section{PORTUNITES ALASKENSIS, new species}

Plate 18, figs. 3 and 4 ; plate 22 , fig. 3

Description.-Outlines of carapace (pl. 18, figs. 3 and 4): None of the specimens shows an entire lateral spine and only one (N. Pac. 128) has the basal half preserved; this is subtriangular in outline and points directly outward and very slightly upward. Orbital tooth pointing forward, subacute, sides convex; next three lateral teeth acute, sides concave, the second one longest, the first one smallest and close to the orbital tooth. Position of orbital fissures indicated only by slight depressions in the surface; orbital margin finely crenulate. Front narrow; two small submedian teeth separated by a V-shaped emargination and followed by a sinuous margin; outer angle subrectangular, corner rounded off. A slight superior inner orbital angle raised above level of front. Postero-lateral margin of carapace sinuous; posterior margin slightly incurved at middle.

4 Monog. Foss. Malac. Crust. Great Britain, Part 1, London, 1857 (1858), p. 21, pl. 3, figs. 1-5. 
Areolation of carapace: Mesogastric region small, the narrow portion almost linear posteriorly, widening a little anteriorly and terminating in a pointed furrow which is continued by a narrow sulcus leading to the edge of the front. From in front of the inner angle of the branchial region a blunt transversely arched ridge runs to the lateral spine. Behind and a little outside its origin a longitudinal ridge extends backward and a little outward, stopping short of the posterior margin. A conical tubercle at inner angle of branchial region. On either side of the cardiac-intestinal constriction a crescentic elevation concave outward. A row of about seven very irregular tubercles lies in front of and parallel to the transverse branchial ridge. A transverse blunt ridge across the protogastric lobes. Epigastric lobes elevated and also the hepatic.

Ventral aspect: The ischium of the outer maxillipeds has a deep, slightly oblique furrow; the merus is produced at its outer angle, the surface is uneven, inner angle notched; exognath reaching antero-external angle of merus. Abdomen of male with fourth to seventh segments together triangular; third segment narrowing at either end to a blunt tip.

Chelipeds and legs: Of moderate length; merus extending but little beyond carapace (pl. 18, fig. 4) ; carpus squarish in dorsal aspect, the distance from the merus to the opposite side less than the length in the other direction. Chela short in relation to height; palm thick, upper and lower surfaces rounded, outer surface with a broad blunt longitudinal ridge; upper distal angle rectangular; dactylus articulated below top of palm. Both fingers broad, not gaping, the fixed finger broader at base than the dactylus.

Following is a description of chela, N. Pac. 253 (pl. 22, fig. 3), supposed to belong to this species: Only the surface of the distal end of the manus and of the fingers is visible. Surface finely and evenly granulate; distant, scattered punctae larger than the granules; a row of punctae along the base of the prehensile teeth. Fingers long; gradually diminishing, deflexed; a deep groove on less than the distal half of fixed finger, and a shallow groove about as long next to the teeth; two very shallow grooves on dactylus; prehensile edges irregularly dentate, four teeth larger and more prominent than the others and separated by from two to four smaller teeth. The large teeth of one finger fit in to the intervals between the large teeth of the other finger, so that there is little or no gape. Outer surface of palm bending strongly over to the upper surface; there is no further evidence of carination on the short length of palm visible.

The ambulatory legs are slender. The last or swimming foot is preserved in only two cases; the propodus is narrow, the dactylus suboval. 
Measurements.-Holotype, length of carapace $18.4 \mathrm{~mm}$. , width in front of lateral spine $27.9 \mathrm{~mm}$.; fronto-orbital width $20 \mathrm{~mm}$., width of front $6 \mathrm{~mm}$., length of chela, top view $17.5 \mathrm{~mm}$., length of palm, same view, $9 \mathrm{~mm}$. Approximate length of impression of carapace (Washington, 80) $30.6 \mathrm{~mm}$., width in front of lateral spine $42.6 \mathrm{~mm}$.

Occurrence.-

ALASKA

East branch of Redwood Creek; Oligocene series; 12 specimens including 2 males and 3 females; one specimen embedded in a nodule is selected as holotype; in University of California.

Nichowak District, just below the lower seepage on Pearl Creek, on Pearl Creek oil claim No. 11; Oligocene series; two specimens (one male).

\section{WASHINGTON}

Sandstone and shale sea cliffs along west shore of Oak Bay, 1 to 2 miles south of Portage Spit between Port Townsend and Port Ludlow; lower (?) Oligocene series; one specimen.

Sea cliffs between Classens Wharf and the ship canal estuary, Townsend Bay; lower Oligocene series; small fragment of finger.

Vance's Creek, two and one-half miles above junction with Skokomish River, 13 miles above Union; lower Oligocene; one specimen and impression, also one palm.

Tuffaceous sandstone bluffs along the Willapa River north of Holcomb; middle Oligocene; two specimens, a chela and a portion of a large finger.

One thousand six hundred feet above first railroad bridge on Willapa River below Holcomb; section 25, township 13 north, range 8 west; Oligocene series; impression of a large specimen.

OREGON

Near Eugene; upper Oligocene series; one specimen and impression.

Relations.-This species is easily distinguished from the two preceding by its shape; the carapace is squarer, the orbits wider, the anterolateral margin shorter. The shape is much like that of certain of the Goneplacidae, as, for example, Tetraplax ${ }^{25}$ and Euryplax. ${ }^{26}$ The areolation, on the other hand, is similar to that of the two preceding species. The upper as well as the under surface of the manus is smoothly rounded, as in Euryplax, not provided with ridges as in $P$. triangulum described above and as in most Portunids. The outer

${ }^{25}$ Rathbun, Bull. U. S. Fish Comm., vol. 20, for 1900, pt. 2, 1901, p. 9.

${ }^{26}$ Stimpson, Ann. Lyc. Nat. Hist. New York, vol. 7, 1859, p. 60. 
surface, however, has a longitudinal ridge through the middle as in $P$. triangulum.

\section{Genus PORTUNUS Weber}

Portunus Weber, Nomenclator Entomologicus, 1795, p. 93 ; type, P. pelagicus (Linnaeus).

Carapace transverse, little convex. Front cut into three to six, usually four teeth; antero-lateral borders oblique, arched, longer than postero-lateral, cut into nine teeth, of which the ninth may be enlarged. Orbits often with a dorsal inclination, inner angle usually very prominent. Chelipeds massive; spines on arm and inner and outer angles of wrist; palm prismatic, costate, usually spined ; fingers usually nearly as long as palm, strongly toothed. Legs of last pair adapted for swimming. Abdomen of male triangular.

Miocene; Pleistocene; Recent.

\section{PORTUNUS (PORTUNUS) XANTUSII (Stimpson)}

Achelous xantusii Strmpson, Ann. Lyc. Nat. Hist. New York, vol. 7, 1860 (1862), p. 222.

Portunus xantusii Schmit, Univ. California Publ. Zoöl., vol. 23, 1921, p. 237, text-fig. 141, and synonymy.

Occurrence.-California: Spanish Bight, San Diego Bay; Pleistocene series; one fixed finger; Cat. No. 353349, U.S.N.M.

Range of Recent specimens.-From Santa Monica Bay, California, to Chile. Puget Sound (accidental).

\section{Genus CALLINECTES Stimpson}

Callinectes Stimpson, Ann. Lyc. Nat. Hist. New York, vol. 7, 1860, p. 220 ; type, $C$. sapidus Rathbun.

Of large size. Carapace broad, areolated, antero-lateral margin long, armed with nine strong teeth, the last being elongated in a spine. Front either four or two toothed. Manus with five external costae and not more than two teeth or spines; fingers long, prehensile; teeth stout. Legs of last pair adapted for swimming. Abdomen of male very narrow, 1 -shaped.

Eocene; Oligocene; Miocene; Pleistocene; Recent.

CALLineCtes Bellicosus (Stimpson)

Lupa bellicosa Stimpson, Ann. Lyc. Nat. Hist. New York, vol. 7, 1862, p. 57. Callinectes bellicosus Schmitт, Univ. California Publ. Zoöl., vol. 23, 1921, p. 236 , text-fig. 140 , and synonymy.

Occurrence.-California; Signal Hill (or Los Cerritos), northeast of Long Beach; upper San Pedro formation, Pleistocene series; left immovable finger (distal two-thirds) of a large specimen. 
Range of Recent specimens.-From Point Loma, California, to the Gulf of California.

\section{Subtribe Oxystomata de Haan}

\section{Family LEUCOSIIDAE Dana}

Carapace more or less hemispherical, hard; afferent openings to gill chambers situate on either side of mouth at base of third maxillipeds. These last completely close the buccal cavern, the palp wholly concealed by the triangular merus. Antennae small. Legs normal. Abdomen hidden under thorax. Male and female genital openings sternal.

\section{Genus RANDALLIA Stimpson}

Randallia Stimpson, Proc. Boston Soc. Nat. Hist., vol. 6, 1857, p. 85; type, $R$. ornata (Randall).

Carapace strongly convex, subhemispherical, evenly rounded at sides, two lobes or teeth on posterior margin. Front narrow, very short, anterior margin concave. Merus of outer maxillipeds not much shorter than ischium, reaching nearly as far forward as front Chelipeds rather long, hand narrow, fingers acute and somewhat compressed.

Pleistocene; Recent. Not before found fossil.

\section{RANDALLIA ORNATA (Randall)}

Plate 1, figs. 13 and 14

Ilia ornata RAndel, Journ. Acad. Nat. Sci. Philadelphia, vol. 8, 1839, p. 129.

Randallia ornata Sснмітт, Univ. California Publ. Zoöl., vol. 23, 1921, p. 188, text-fig. 116, and synonymy.-T. S. OLdroyd, Proc. U. S. Nat. Mus., vol. 65 , art. 22,1924 , p. 23.

Occurrence.-California; Pleistocene:

Rincon del Potrero, Santa Monica; about 500 arms, 30 fingers and 1 hand with wrist attached; Cat. No. 353345 , U.S.N.M.

Long wharf, Santa Monica; two arms; Cat. No. 353344, U.S.N.M. Nob Hill (lumber yard), northeast of San Pedro; lower San Pedro formation; one arm and fragments of two others.

Deadman Island, southeast of San Pedro; six arms.

Signal Hill (or Los Cerritos), north of Long Beach; 14 arms and 2 movable fingers (pl. 1, fig. 13).

Spanish Bight, San Diego Bay; 13 arms, 1 immovable finger (pl. 1, fig. 14).

Range of Recent specimens.-From Mendocino County, California, to Magdalena Bay, Lower California. 
Plate 1, figs 11 and 12

Randallia, new species, T. S. Oldnoyd, Proc. U. S. Nat. Mus., vol. 65, art. 22,1924 , p. 23.

Description.-Holotype: Manus much swollen inside in the proximal two-thirds; viewed from the outside the upper margin is slightly curved, lower margin strongly arcuate, the propodal finger inclined obliquely downward (pl. 1, fig. 12). Surface covered with round bead tubercles of good size, the interspaces filled by granules; tubercles largest on the swelling of the inner surface where they are more unequal than on the outer surface. Manus much rougher than in $R$. ornata, and shorter in proportion to its width. Fixed finger long and narrow, densely granulate; two ridges running lengthwise through the middle of the outer and of the inner surface and a similar ridge on the lower edge; in $R$. omata the pair of ridges on the outer surface is nearer the lower margin; prehensile edge multidentate, teeth crowded, every third or fourth one of larger size.

Arm more coarsely tuberculate than hand, a little bent at the inner third, as in ornata; it is somewhat stouter than in ornata, the tubercles are nearer together, giving the surface a much rougher appearance (pl. 1, fig. 11).

Measurements.-Length of largest arm (Deadman) $11.6 \mathrm{~mm}$., width $4.1 \mathrm{~mm}$. Holotype, length of propodus (tip broken off) 8.2 mm., length of fixed finger $3.4 \mathrm{~mm}$., height of palm $2.8 \mathrm{~mm}$.

\section{Occurrence.-California :}

Nob Hill (lumber yard), northeast of San Pedro; lower San Pedro formation, Pleistocene series; three hands with fixed finger attached (one of which is the holotype), and six arms; Cat. No. 353346, U.S.N.M.

San Pedro; Pleistocene: Kate Stephens collector; four arms.

Deadman Island, southeast of San Pedro; Arnold collection, Stanford University; 16 arms.

\section{Genus PERSEPHONA Leach}

Persephona LeAch, Zoöl. Misc., vol. 3, 1817, pp. 18 and 22 ; type, P. punotata (Linnaeus).

Carapace ovoid or subglobular; three posterior spines, of which two are at extremities of posterior border, the other median and higher up. Front well advanced; regions little marked; hepatic region generally separated from branchial region by a broad notch in the margin. Orbits deep. Merus of outer maxillipeds not much 
over half length of ischium measured on inner edge. Chelipeds stout; fingers slender, curved, prehensile edges denticulate.

Oligocene; Miocene; Recent.

\section{PERSEPHONA BIGRANULATA, new species}

Plate 11, figs. 5-8

Description.-Carapace (pl. 11, fig. 6), excluding front and spines, almost circular; the three posterior spines are broken off near the base, two are at the ends of the posterior margin, the median spine well above that margin (pl. 11, fig. 8). The surface is covered with two sorts of granules, (1) bead granules ${ }^{27}$ of small size but still visible to the unaided eye and present everywhere except on the slope of the front and orbits and in the branchio-hepatic hollow and (2) very minute granules filling all the interspaces but not touching one another. Regions not well defined. Hepatic region slightly elevated. Front broadly bidentate, prominent dorsally, not so advanced as to conceal the ends of the branchial channels. The upper part of the front is granulate. Orbits round; two closed fissures in upper surface, a deep smooth gutter on outer surface; otherwise the outer surface of the orbit as well as of the projecting and obscurely-facetted side-wall of the hepatic region is coarsely granulate, and has no well defined marginal line. At the base of the front, between it and the gastric region there is on either side a shallow hollow, and another exists opposite the constriction between hepatic and branchial regions. The margin of the branchial region (pl. 11, fig. 7) is marked by a rim of bead granules considerably larger than those of the dorsal surface. The intestinal region is dimly outlined laterally at least by a curved, shallow, impressed line which ends outside of, and before it reaches, the lateral spine. The surface about the spines and on the posterior margin is coarsely and densely granulate without forming a marginal line. The lower surface of the carapace is densely but finely granulate, a large hollow is beneath the lateral constriction.

Sternum (pl. 11, fig. 5) densely granulate and very coarsely so at base of chelipeds; first, second, third, and base of fourth segment of abdomen granulate; remainder of abdomen smooth. The abdomen indicates maturity; it is filled with oblong concretions resembling superficially foraminifera. They are probably formed about masses of the minute eggs common to this genus. Chelipeds and legs are wanting and the maxillipeds cannot be made out.

Measurements.-Female holotype, length of carapace exclusive of spine $23.2 \mathrm{~mm}$., width of same $20.7 \mathrm{~mm}$., fronto-orbital width 4.7 mm., width of intestinal region $9.1 \mathrm{~mm}$.

${ }^{27}$ Many of these granules are elongated apparently by a deposit of mud small particles of which have perhaps been swept against them and adhered to their anterior side. The granules thus affected are chiefly on the right side of the carapace. 
Occurrence.-Oregon: 1 mile south of Henderson Station (Springfield Junction), Southern Pacific Railroad, Lane County; Oligocene series; one female, showing carapace and abdomen, Cat. No. 353566, U.S.N.M. "Horizon 200 or 300 feet above the other specimens."

Relation.-This species is nearest to $P$. subovata Rathbun ${ }^{28}$ from the Gulf of California, which has a higher hepatic region, a marginal line of granules on the hepatic region and between the two posterior spines, and fewer dorsal granules and those more or less sunken.

\section{Family CALAPPIDAE Dana}

Carapace more or less oval or subcircular. Afferent openings to gill chambers lie in front of chelipeds. Antennae small. Legs normal. Male genital openings coxal, female sternal.

\section{Genus CALAPPA Weber}

BOX CRABS

Calappa WeBER, Nomenclator Entomologicus, 1795, p. 92 ; type, C. granulata (Linnaeus).

Carapace strongly convex, rounded in front, much broadened behind by a pair of clypeiform wings, beneath which the legs are concealed in flexion. Front small, somewhat triangular, bilobed; orbits small, circular. Chelipeds very large and in flexion fit closely the front half of carapace; the arm has an outer distal wing; hand strongly compressed, its upper border forming a high dentate crest. Chelipeds equal except for the fingers which on one hand have outside near the base a stout projecting lobule. Abdomen of adult with third, fourth and fifth segments fused.

Eocene-Recent.

CALAPPA LANENSIS, new species

Plate 19, figs. 1 and 2

Description.-The postero-lateral tooth is triangular (pl. 19, fig. 1), broader at base than the length of its sides, spine-tipped, spine broken off. In front of this tooth there is a row of five teeth on the wing, of which the first or most posterior reaches laterally a little further than the postero-lateral tooth; the others become progressively smaller, the last two very small and little projecting. The posterior border of the wing bears two teeth, smaller than the postero-lateral tooth and more projecting, the inner tooth smaller than the outer. The median portion of the posterior border is still more produced and divided into three shallow lobes, the middle one twice as broad as the outer ones. Lateral and posterior margins granu- 
late. Outer orbital tooth not prominent; inner orbital tooth high. Frontal teeth broken off.

The carapace is traversed by two longitudinal, submedian furrows and a transverse depression behind the orbits. Surface of carapace and chela granulate, the granules visible without a lens and near together but not touching except on the tubercles. Three rows of five tubercles each; of the median tubercles the two anterior are the largest; of the lateral tubercles the three anterior are large and the second one, counting from the front has a small, low tubercle on its anterior, inner slope. Outside this row on each side there are about 8 or 10 very low and inconspicuous tubercles irregularly placed.

The transverse distal crest (pl. 19, fig. 1) of the merus of the minor cheliped is furnished with four teeth increasing in size below from above, the two lower teeth prolonged in a spine. Surface of carpus uneven, scarcely nodulous. Lower edge of manus (pl. 19, fig. 2) straight; a longitudinally oblique furrow not far above lower margin; it is smoother than the rest of the surface. Tubercles of rather small size, arranged roughly in three transversely oblique rows, four tubercles in the distal row, five in the next, three in the proximal row. Eight teeth on upper border, of which six are crowded together forming the cock's comb, and the other two teeth are on the slope leading down to the carpus. The customary large tooth or spine is situated at the infero-proximal angle of the outer surface, but it is in great part broken off. The outer aspect of the proximal half of the dactylus is granulate; prehensile teeth and distal half of the dactylus dark colored.

Measurements.-Holotype, length of carapace $27.8 \mathrm{~mm}$., width of same $35.7 \mathrm{~mm}$., length of minor manus measured from articulation of carpus to sinus between fingers $16 \mathrm{~mm}$., distal height measured to base of teeth $14.8 \mathrm{~mm}$.

Occurrence.-Oregon: 1 mile south of Henderson Station (Springfield Junction), Southern Pacific Railroad, Lane County; Oligocene series; one carapace with minor chela; Cat. No. 353350 , U.S.N.M. "Horizon 200 or 300 feet above the other specimens."

Relation.-In shape resembles $C$. flammea, the Recent species found on the east coast of the United States and southward; also in the Miocene of Santo Domingo and the Pleistocene of Panama. The carapace of the latter is much more extensively tuberculated and the granulation more crowded; there is a small tooth on the posterior margin between the submedian lobes and the teeth of the alate expansion. The tubercles of the palm are distributed just as in the fossil species, but those of the upper half and of the proximal row are larger in flammea than the corresponding ones in lanensis. 


\section{Genus MURSIA Leach}

Mursia LeACH, in Desmarest, Dict. Sci. Nat., vol. 28, 1823, p. 231; type, M. cristata Latreille (Recent).

Carapace very convex, transversely oval, a strong spine at lateral angle; front narrow. Chelipeds large, when folded fitting close to body; hands large, compressed, distally widened, a superior laminate and dentate crest, and a strong longitudinal ridge near lower edge of outer surface.

Oligocene; Recent.

MURSIA YAQUINENSIS, new species

Plate 19, figs. $3-5$

Description.-Surface of carapace (pl. 19, fig. 5) covered with fine granules which vary in size and prominence; those of the posterior half are finer than those of the antero-lateral half; those on the tubercles are large and more crowded than elsewhere. The branchial region is crossed by three blunt, oblique ridges; the inner ridge is nearly longitudinal and bears three tubercles, the distance between the second and third (posterior) being one and a half times that between the lateral spine (missing in the holotype) and is directed forward at an angle of about 45 degrees to the median line; it is furnished with two tubercles; the outer ridge is very faint, nearly transverse and also bears two tubercles. Twelve smail antero-lateral teeth are indicated, only one of which approaches completeness; they are connected by a single row of marginal granules, three or four grantles in each interval; the teeth nearest the orbit are smaller than the others. A raised rim of crowded bead granules marks the postero-lateral margin. A portion of the ventral surface bordering the lateral margin is preserved (pl. 19, fig. 3): it is coarsely granulate, the granules spaced and directed outward; this area is separated from the smooth pterygostomian region by a narrow, raised band of smaller and closer granules separated by minute punctae which probably served as sockets for hairs.

The sternum is represented by portions of three segments of the right side, that at the base of the cheilped bearing the strong, curved, downward pointing spine (pl. 19, fig. 4) which characterizes the male; this segment is finely granulate except on and behind the spine where it is coarsely so; the coarse granules are continued on the next segment, except the inner half which was covered by the abdomen and is smooth; only the inner or smooth half of the next segment is visible.

Alongside the carapace there is a fragment of the proximal end of the merus of the posterior leg; it is granulate on the upper sur- 
face without forming a definite marginal line; on the outer surface the granules almost disappear.

Measurements.-Male, holotype, length of carapace from outer angle of orbit $34.7 \mathrm{~mm}$., chord of antero-lateral margin, from outer angle of orbit to the interval behind the twelfth tooth (orbital tooth not counted) $24.5 \mathrm{~mm}$.

Occurrence.-Oregon: Rocky Point, 4 miles east of Yaquina City; Oligocene series; one specimen, holotype, showing less than half the carapace and a piece of the sternum with spine; in University of California.

Relation.-This species is closely allied to $M$. gaudichaudii (Milne Edwards) ${ }^{29}$ which inhabits the deeper waters of the Pacific coast from the Farralon Islands to Chile at a depth of 26 to 218 fathoms. The antero-lateral teeth are of the same character and the ridges of the carapace are similarly placed and have the same number of tubercles. In gaudichaudii the two posterior tubercles of the inner branchial ridge are nearer together, scarcely further apart than are the two anterior tubercles of the same ridge. In gaudichaudii the number of antero-lateral teeth varies from 13 to 15 ; our species may have had as many, for the margin is broken away at the widest part of the carapace. The granulation of carapace and sternum is more uniform and more crowded in gaudichaudii, and the merus of the ambulatory legs more compressed.

\section{MURSIA MARCUSANA, new species}

Plate 19, figs. 6 and 7

Description.-Antero-lateral margin strongly arched (pl. 19, fig. 6 ), postero-lateral margin equally long, the strong lateral spines broken off at base; posterior margin slightly obtuse-angled at middle, and furnished at either end with a tooth or spine now broken off. Carapace traversed by five strong tuberculate ridges, one median, the others branchial and oblique; median ridge with five strong tubercles, the branchial ridges with three tubercles each; in addition there are on the anterior half of the carapace about eight smaller tubercles on each side; the tubercles are coarsely and densely granulate, the intervening spaces also granulate, the granules spaced and coarser in front and very fine behind. Details of front and orbits lacking. Infero-posterolateral area subtriangular, the surface rising in a point and forming a small tubercle where it meets the posterior of the branchial ridges. Margins finely granulate.

In its form, strong dorsal ridges, and pair of posterior teeth this species approaches $M$. hawaiiensis. ${ }^{30}$ In the fossil the ridges are

zo Platymera gaudichaudii Milne Edwards, Hist. Nat. Crust., vol. 2, 1837, p. 108.

${ }^{30}$ Rathbun, Bull. U. S. Fish Comm. for 1903, part 3, 1906, p. 887, pl. 18, figs. 3 and 4. 
much higher and depressions deeper and the postero-lateral facet of different form.

Description of the manus.-The oblique upper edge of the palm (pl. 19, fig. 7) shows five spines followed at the proximal end by a round lobe which appears to be at the articulation with the carpus, as the lobe is set off by the customary furrow; the superior spines I will designate in order of their position, the first being the most distal shown, although it may not really be the end spine; the first spine is shorter and narrower than the second; the second to fifth, inclusive, get progressively shorter, the fourth appears obliquely truncate, the fifth lobiform. On the outer surface considerably below the spines there is a row of three large, prominent tubercles, one behind the first spine, one behind the third, and one behind the articulating condyle; these tubercles are not in a straight line, the distal one being more distant from the base of the spines than are the other two. There is also an indication of a tubercle on the base of the first spine. The surface is sprinkled with very unequal granules, those on the tubercles large and more numerous, while on the spines they are in part of large size. Below and slightly distad to the middle tubercle is another tubercle the top of which is broken off. At the proximal end, above the lower margin there is a broken edge of a large spine or tubercle, oval in cross-section. A portion of the lower edge of the hand remains and shows vestiges of eight triangular spines (there were probably several others); they are directed at right angles to the margin, are of larger size than is customary in Recent species, and very unequal, with a few granules on the outer surface. The arrangement of tubercles and of marginal spines is unlike any species yet described.

The portion of a manus from Bainbridge Island has finer granules between tubercles.

Measurements.-Length of holotype $18.4 \mathrm{~mm}$., width to anterior base of lateral spines $21.3 \mathrm{~mm}$.

Occurrence.-Washington: Restoration Point, Bainbridge Island, Kitsap County. Blakeley formation, upper Oligocene. Holotype, a specimen of carapace embedded in nodule, showing dorsal surface. From the same locality, a second specimen was obtained somewhat larger than the type. University of Washington Loc. 164, N. Pac. 103, Loc. T. 1. Only the posterior and postero-lateral part of the carapace is exposed, and a portion of the right cheliped. Posterior width of carapace $7.4 \mathrm{~mm}$.

Washington: Shaly sandstone beach from Alki Point south onefourth mile along shore of Puget Sound, Seattle; upper Oligocene; H. Hannibal, collector, Stanford University (N. Pac. 48); a left inanus. 


\section{Genus HEPATUS Latreille}

Hepatus Latreille, Hist. Nat. Crust., vol. 3, 1801-1802, p. 22 ; type, $H$. princeps (Herbst).

Carapace broad, convex, regularly arcuate in front, strongly narrowed behind; hepatic regions very large, branchial very small. Front narrow, straight, rather prominent; orbits small, circular; antero-lateral margin prolonged beneath the orbits to join margin of buccal cavity. Chelipeds strong, when flexed fit closely against lower surface of body. Hands with a superior crest, fingers inclined downward and inward. Abdomen of seven segments.

Oligocene; Pleistocene; Recent.

\section{HEPATUS LINEATUS Rathbun}

Hepatus lineatus Rathbun, Proc. U. S. Nat. Mus., vol. 21, 1898, p. 610, pl. 44, fig. 4.

Occurrence.-California; Pleistocene:

Signal Hill (or Los Cerritos), north of Long Beach; one large dactylus of right cheliped; Cat. No. 353361, U.S.N.M.

Spanish Bight, San Diego Bay; one small dactylus of right cheliped; Cat. No. 353362 , U.S.N.M.

These fingers are distinguished at once from others found at the s ame localities by the longitudinal, finely milled, stridulating ridge on the inner surface, a little below the upper edge and running the whole length of the finger except on the horny tip.

Range.-This Recent species has never been taken on the California coast but only off Abreojos Point and in Magdalena Bay, Lower California.

\section{Genus NECROCARCINUS Bell}

Necrocarcinus BeLL, Monog. Fossil Malac. Crust. Great Britain, 1862 (1863), p. 19 ; type, N. bechei (Deslongchamps).

Carapace suborbicular, furnished with large tubercles arranged in regular lines, antero-lateral margin arcuate, dentate, front triangular. Orbits round, with a dorsal and forward aspect, bifissured above. Hand high, fingers shorter.

Cretaceous; Eocene.

NECROCARCINUS HANNAE, new species

Plate 18, figs. 1 and 2

Description.-Surface covered with minute, crowded punctae, invisible to the naked eye. A broad furrow divides the median regions from the lateral regions; alongside the gastric region the furrow is deep, but at the cardiac region it becomes shallow and disappears altogether before reaching the posterior margin. The division between the hepatic and branchial regions is shallow, not well defined. 
The mesogastric region anteriorly narrows gradually not suddenly. There are 15 dorsal tubercles (pl. 18, fig. 1): one on each protogastric region; two mesogastric, the posterior one large and high, the anterior one low; the cardiac elevation large and low; two epibranchial tubercles placed obliquely not far apart; one metabranchial at the end of a blunt ridge which runs obliquely forward and outward from the postero-lateral angle of the carapace; one small hepatic tubercle; one small low tubercle in the depression at the inner angle of the branchial region. The lateral margin is thick and unmarked by a raised or granulated line (pl. 18, fig. 2). There are three lateral spines or teeth behind the orbit; all are broken off except the left one of the pair situated a little behind the middle of the carapace; it is short, conical, blunt; the distance between it and the second spine is nearly twice that between the first and second. The orbital margins are broken away but there is indication of a forward-pointing spine at the outer angle and another near the middle of the upper margin; farther inward are the bases of two other spines or teeth and below the outer of these two projects at some distance the spine at the inner angle of the lower margin of the orbit (lo, fig. 1, pl. 18).

Measurements.-Greatest width of carapace exclusive of spines 21 mm., posterior width $10.7 \mathrm{~mm}$., width across front and orbits 14.2 $\mathrm{mm}$, length from one of the submedian spines of the frontal margin to the posterior margin $19.3 \mathrm{~mm}$.

Occurrence.-California: 1 mile southeast of Oil City, Fresno County; Eocene series (Tejon of Arnold); one specimen of carapace with anterior margin lacking; holotype in California Academy of Sciences.

Relation.-This species seems to fit into Necrocarcinus better than into any other fossil genus; it has a similar shape of carapace, of mesogastric region, possesses lateral spines and a few dorsal tubercles. On the other hand, the gastric region as a whole is wider than those figured by Bell for his three species of Necrocarcinus and suggests rather the genus Orithyia ${ }^{31}$; the arrangement of the orbital spines as I see it is similar to that in Orithyia, but the shape and lateral spination is quite different.

\section{Subtribe Dromiacea de Haan}

\section{Superfamily HOMOLIDEA Alcock}

\section{Family HOMOLIDAE Henderson}

Carapace longer than broad, more or less quadrilateral, ovoid, or urn-shaped; linece anomuricae (a pair of longitudinal suture lines 
on carapace) usually present; sternum of female not longitudinally grooved. Eyes not retractile into orbits nor antennules into pits. External maxillipeds pediform or subpediform. Legs long and slender, only fifth pair dorsal and reduced. Uropods wholly absent.

\section{Genus HOMOLOPSIS Carter, MS., Bell}

Homolopsis Carter in Bell, Monog. Fossil Malac. Crust. Great Britain, 1862 (1863), p. 22 ; type, H. edwardsii Bell.

Carapace longer than broad, high, quadrilateral, tuberculate; regions distinct; branchial region large, triangular; frontal region produced, orbits close together, subrotund, one superior fissure; antennal fossae oval, transverse; epistome strongly pentagonal.

Cretaceous; "Tertiary."

\section{HOMOLOPSIS RICHARDSONI Woodward}

Plate 20, fig. 3

Homolopsis richardsoni Woodward, Quart. Journ. Geol. Soc. London, vol. 52, 1896, p. 224, text-fig. 3.-Whiteaves, Mesozoic fossils, vol. 1, pt. 4; Geol. Sur. Canada, Ottawa, 1900, p. 266, text-fig. 13.

Occurrence.-British Columbia: Skidegate Inlet, west of Alliford Bay, Queen Charlotte Islands. Cretaceous. Type in Museum of the Geological Survey, Ottawa.

\section{PALEHOMOLA, new genus}

Type.-P. gorrelli, new species.

Carapace broadly ovate, narrowing anteriorly to a two-horned rostrum. Two abdominal somites visible in dorsal view. Chelipeds very long and strong.

\section{PALEHOMOLA GORRELLI, new species}

Plate 21, figs. 1 and 2

Description.-Carapace (pl. 21, fig. 1) thick, ovate, sides steeply inclined, posterior margin concave at middle, exposing the first two segments of the abdomen, branchial regions laterally expanded, the epibranchial regions separately arcuate, as are also the hepatic regions. Front furnished with two short, curved (concave inward) horns.

Very little of the surface of the crab remains; that which exists on the posterior portion is finely wrinkled and still more finely punctate. Linea homolica partially visible on left side. The cervical groove is rather deep, the branchial groove less evident; the branchial regions slope gently downward to a median point behind the cardiac region. There is a high punctate posterior rim. A median and a 
lateral tubercle on the intestinal region. The second abdominal segment is raised in a tubercle.

The left cheliped reaches beyond the carapace as far as the length of the carapace (pl. 21, fig. 1), the right appears smaller; they are both stout, with carpus and manus elongate, larger manus increasing a little in height distally (pl. 21, fig. 2); a cross-section near the proximal end is subcircular, height $11.5 \mathrm{~mm}$., thickness $9.3 \mathrm{~mm}$.; its outer, upper and under surfaces are covered with tubercles or coarse granules. Similar but larger tubercles are to be seen on the right merus and carpus. The basal part of the immovable finger is at its attachment less than half as high as palm, thick and gradually tapering. The merus of an ambulatory leg is narrow with a somewhat sinuous outline, surface wrinkled, upper margin with a row of appressed spines. Of the ventral surface the only exposures are a small article, apparently the ischium of the chelipeds.

Measurements.-Male holotype, median length of carapace $36 \mathrm{~mm}$., extreme length of carapace $41.5 \mathrm{~mm}$., greatest width of same $39.4 \mathrm{~mm}$., width at hepatic regions $31 \mathrm{~mm}$., posterior width $27 \mathrm{~mm}$., distance between horns $5 \mathrm{~mm}$., length of merus of an ambulatory leg, perhaps of the penult pair $30 \mathrm{~mm}$.

Occurrence--Oregon: Judkins Ridge, near Eugene; Oligocene series in sedimentary tufaceous sandstone; one specimen, male, holotype (Cat. No. 352912, U.S.N.M.).

Relation.-This form differs from other Homolidae in its form, which is more broadly ovate, the sides converging from the widest part, the middle of the branchial regions, to a narrow front. In other Homolids the carapace is of moderate width, oblong, changing little in width until near the anterior margin. In its strong horns our species resembles Homolus (=Palaeinachus) longipes (Woodward $)^{32}$ from the Jurassic.

It is possible that the new form should be placed in the Latreilliidae. Latreillopsis Henderson ${ }^{33}$ approaches it in the prominence of the hepatic region but is not rotund; has a median rostral spine, which Palehomola is not known to have, as well as a supraocular spine on either side; the strong, rough chelipeds of our species are similar to those of $L$. petterdi Grant. ${ }^{34}$

\section{Superfamily DROMIIDEA Ortmann}

\section{Family DROMIIDAE Alcock}

Carapace subglobular, rarely fiattened; no lineae anomuricae; two obliquely longitudinal grooves on sternum of female. Eyes and

\footnotetext{
${ }^{2}$ Quart. Journ. Geol. Soc. London, vol. 22 , 1866, p. 494, pl. 24, fig. 1.
33 Challenger Rept., vol. 27, 1888, p. 21.

${ }^{34}$ Proc. Linn. Soc. New South Wales, vol. 30,1905 , p. 317 , pl. 10, figs. $2,2 a, 2 b$.
} 
antennules almost always retractile into common orbito-antennulary pits. External maxillipeds generally operculiform. Legs of moderate size, fourth and fifth pairs short, subdorsal, and furnished with a small, hook-iike nail. Sixth segment of abdomen generally with rudimentary uropods.

\section{Genus GRAPTOCARCINUS Roemer}

Graptocarcinus Roemer, Neues Jahrb. f. Mineral., Geol. u. Palaeont., 1887, vol. 1, Stuttgart, p. 173 ; type, G. texanus Roemer.

Carapace transversely oval or five-sided, marginate, much swollen dorsally, with almost no indication of regions except for short furrows in center of carapace. Rostrum shallow; orbits deep.

Cretaceous; Oligocene.

\section{GRAPTOCARCINUS (?), species}

\section{Plate 21, fig. 3}

Description.-A damaged remnant encased in a nodule. The characters shown are too scanty for accurate determination. The ventral aspect is uppermost but the true surface has been destroyed; the general outline of the orbits is apparent and the right eye is preserved; for this reason it seems valuable to place the specimen on record. The carapace except for the fronto-orbital region is suborbicular. The orbits are suboval, nearly meet on the median line and are forward looking; the eye is of moderate size, not filling orbit, slightly enlarged at the cornea (pl. 21, fig. $3 \mathrm{c}$ ), and in place points obliquely outward and downward parallel with the orbit. Outer angle of orbit blunt, little advanced, its outer margin convex, continued on the hepatic region and forming an entering angle with the branchial margin. Owing to the proximity of the orbits, the front appears to have been narrowed or pointed at the tip. The epistome and interantennular septum as well as the maxillipeds have been broken away, leaving a raised border which anteriorly is oblique, but alongside the buccal cavity is longitudinal. Further details are obscured.

Measurements (approximate).-Length of carapace $13.8 \mathrm{~mm}$., width of same $13 \mathrm{~mm}$.

Occurrence-Oregon: Springfield Junction, 1 mile west of Springfield, Lane County; Oligocene; one specimen, showing the eye and orbits, general outline of the carapace, and position of the buceal cavity, Cat. No. 353565, U.S.N.M. 
Relation.-The genus Graptocarcinus ${ }^{35}$ was described from a species $^{36}$ in the upper Cretaceous of Texas. Our species has a greater fronto-orbital distance, due to the larger orbits, and the carapace begins to widen at a greater distance from the orbits.

\section{Subtribe Gymnopleura Bourne}

\section{Family RANINIDAE Dana}

Anterior thoracic sterna broad, posterior thoracic sterna narrow and keel-like; posterior thoracic epimera largely exposed by reduction of branchiostegite; female openings on coxae; last pair of pereiopods dorsal in position, normal or reduced in size; sternal canal present; thoracic nerve ganglion-chain elongate; antennary sternum triangular spout-shaped; branchiae eight on each side (Bourne).

This family is represented in British Columbia, Washington, Oregon, and California by 12 species distributed in five genera. It is altogether absent to-day from the adjacent waters of the Pacific although occurring further south, from Mexico to Panama.

KEY TO THE FOSSIL GENERA OF THE FAMILY RANINIDAE ON THE PACIFIC SLOPE OF NORTH AMERICA

$\mathbf{A}^{1}$. Carapace of moderate convexity, not egg-shaped.

$B^{1}$. Sternum very narrow, or linear, between feet of second to fifth pairs. Carapace very broad in proportion to its length; anterior margin also very broad, with several strong teeth Ranina, p. 89.

$B^{2}$. Sternum broad between feet of first and second pairs.

$\mathrm{C}^{1}$. Sternum very narrow between feet of third to fifth pairs. Anterior margin of carapace narrow, with three teeth

Ranidina, p. 99.

$C^{2}$. Sternum broad between feet of third pair. Fronto-orbital border broad.

$D^{1}$. Sternum linear between feet of fourth and fifth pairs. Width of carapace about half its length. Rostrum simple.

Raninoides p. 92.

$D^{2}$. Sternum gradually diminishing in width from first to fifth sternite. Width of carapace about two-thirds or three-fourths of its length. Rostrum bifid______Palaeocorystes, p. 101.

$\mathrm{A}^{2}$. Carapace extremely convex, resembling half an egg; a prominent midrib; one strong antero-lateral spine Eumorphocorystes, p. 100.

\section{Genus RANINA Lamarck}

Ranina Lamarck, Sys. Anim. sans Vert., 1801, p. 156 ; type, $R$. ranina (Linnaeus).

Sternal plastron linear between bases of feet of second pair. Second article of outer antennae bearing on outer border a large auriculiform prolongation. Anterior border of carapace very wide,

${ }^{35}$ Roemer, Neues Jahrb. f. Mineral., Geol. u. Palaeont., 1887, nol. 1, Stuttgart, p. 173.

${ }^{36} \mathrm{G}$. texanus Roemer, Idem, text-figs. $a, b$.

$3020-26-7$ 
nearly straight, armed with strong teeth, the median one forming a small rostrum; lateral borders curving regularly inward; hind margin very narrow.

Cretaceous; Eocene; Oligocene; Miocene; Pliocene; Recent.

Both species here described fall into Fabiani's division Eteroranina ${ }^{37}$ otherwise typical Ranina.

RANINA TEJONIANA, new species

Plate 22, figs. 1 and 2

Description.-Carapace (pl. 22, fig. 1) very convex from side to side, nearly flat from front to back. Sides of carapace as preserved very arcuate, armed with two depressed spines the origins of which are to be seen on the left side. The posterior of the spines, at the

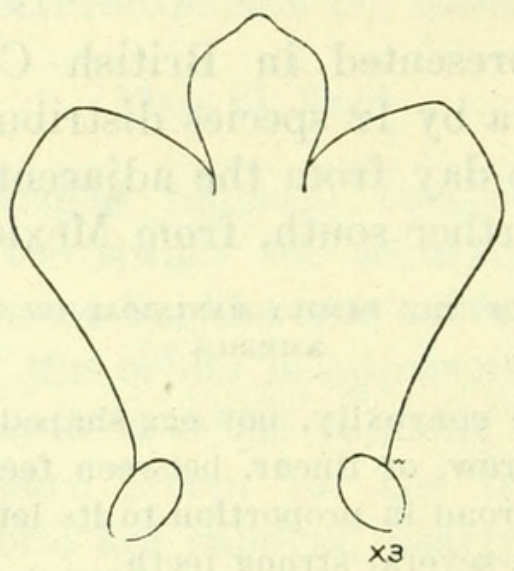

Fig. 1.-RANina tejoniana. Sternum (First SEgment ANd episternum) OF holotype, $\times 3$

antero-lateral angle, is smaller than the other; its cross-section is a little more than twice as long as wide, the cross-section of the larger is three times as long as wide, and the distance between them is equal to the length of the smaller cross-section. The longitudinal distance of the posterior end of the base of the posterior spine from the outer orbital angle is greater than the transverse distance of that angle from the line of the greatest width of the carapace. Only two orbital teeth, the two outermost, are visible; both are truncate, separated by an open suture, inclined a little inward; outer margin of outer tooth very oblique and slightly convex, a point at its outer corner has been broken off. Similar spines may have been present at the corners of the second tooth.

Very little of the true outer surface of the carapace remains; a small piece near the anterior middle is smooth, while another piece

${ }^{37}$ Boll. Mus. Civ. Vicenza, vol. 1, 1910, p. 31; Atti Accad. Sci. Veneto-TrentinoIstriana, ser. 3, anno 3, Padova, 1910, p. 88. 
near the lateral spines bears a few granules directed forward. Underlying surfaces are granulate, the granules thinning out toward the middle.

The pterygostomian regions are swollen (pl. 22, fig. 2). The merus of the left outer maxilliped is fairly complete; it is rather short and broad with a deep inner groove; the outer margin of the exognath is very convex. The episternum is subcircular, broadly pointed at the extremity and invaginated in the first sternal somite from which it is separated by a narrow fissure on each side. The first somite is characteristically broad, the lateral extremities have not been uncovered.

Measurements.-Holotype, greatest width $52.5 \mathrm{~mm}$., fronto-orbital width about $25 \mathrm{~mm}$; hinder end of carapace missing.

Occurrence.-California: West side of Tecuya Creek; southeast quarter of southeast quarter, section 26, township 10-20 west; Eocene series, very close to the type-locality of the Tejon formation; one specimen, holotype, in California Academy of Sciences.

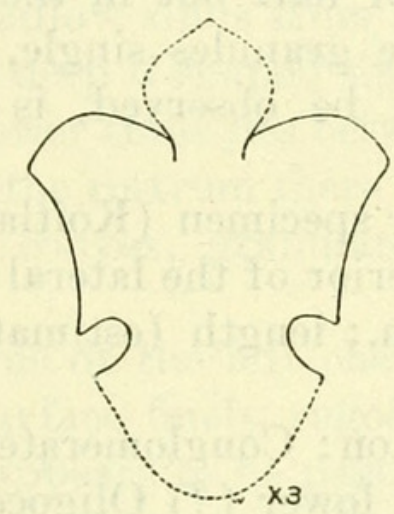

Fig. 2.-Ranina americana. Sternum (first and second Segments) of larger specimen, N. Pac. $167, \times 3$. Episternum after Withers

\section{RANINA AMERICANA Withers}

Plate 23, figs. 1-4

Ranina americana Withers, Ann. Mag. Nat. Hist., ser. 9, vol. 14, 1924, p. 125, pl. 4, figs. 1-3 ; type-locality, Clallam Bay, south shore of Strait of Juan de Fuca, Washington; upper Oligocene, Blakeley formation, in a matrix of greenish grey sandstone; Brit. Mus., Cat. No. In. 23798.

Description.-Viewed laterally the carapace is moderately convex in an antero-posterior direction, and equally convex on its anterior and posterior slopes; the convexity from side to side is much greater. Surface rough with scabrous granules, which are sparse and single on the anterior middle portion, larger and closer posteriorly and toward the lateral and anterior borders where they have a tendency to form in short, transverse rows of two or three granules. The posterior of the lateral teeth is situated at the anterior fourth of the carapace (pl. 23 , figs. 2 and 4 ). It is directed nearly transversely outward and 
is of considerable length, being extended $3 \mathrm{~mm}$. beyond curve of carapace and the tip broken off. Behind the tooth a fine, raised. granulated rim runs in a slightly curved line to the posterior margin; in front of it is a larger tooth curved forward and inward, and similar to the orbital tooth. Anterior margin of carapace incomplete; outer orbital tooth wider than that between the two superior sinuses of the orbit, which in turn is about one-fourth as wide as the distance to the corresponding tooth on the opposite side.

On the ventral surface of the carapace the granules are anteriorly fine and rather dense; arranged more or less in oblique lines; further back, they are larger and more elongate and arranged in short, transverse rows of from four to six granules. Only fragments of the outer maxillipeds remain. The first sternite (pl. 23, fig. 1) is similar in shape to that of $R$. ranina, ${ }^{38}$ but wider. Of the chelipeds only the right one is shown on the smaller specimen as far as the end of the merus (pl. 23, fig. 3 ).

Variation.-In the larger type-specimen, the upper surface is smooth except on anterior half but in the Koitlah specimens it is granulate posteriorly, the granules single, while the center of the carapace, so far as can be observed, is punctate with elongate impressions.

Measurements.-Larger specimen (Koitlah Point), width of cara pace just behind the posterior of the lateral spines $38 \mathrm{~mm}$.; posterior width (estimated) $15 \mathrm{~mm}$. ; length (estimated) $45.6 \mathrm{~mm}$. Type, $4 \varepsilon$ by $60 \mathrm{~mm}$.

Occurrence.-Washington: Conglomerate sea cliffs at Koitlab Point, west of Neah Bay; lower (?) Oligocene; Stanford University (N. Pac. 167) ; two specimens showing the greater part of the dorsa surface and certain portions of the ventral surface and fragments of appendages.

\section{Genus RANINOIDES Milne Edwards}

Raninoides Milne Edwards, Hist. Nat. Crust., vol. 2, 1837, p. 196; type R. loevis (Latreille).

Sternal plastron broad between bases of feet of first, second anc third pairs, narrow between those of fourth and fifth pairs. Cara pace about twice as long as wide; surface almost horizontal longi tudinally but curved transversely. Fronto-orbital border a littl narrower than middle portion of carapace and strongly dentate. A lateral marginal tooth well forward.

Eocene; Oligocene; Miocene; Recent.

This genus, described from a Recent species, is here enriched $b$. seven species extending from the Eocene to the Miocene. Zittel ${ }^{3}$

${ }^{38}$ Cancer raninus Linnaeus, Syst. Nat., ed. 10,1758 , p. 625.

${ }^{20}$ Text-book of Palaeontology, London, vol. 1, 1900, p. 665 ; ed. 2, vol. 1, 1913, p. 765. 
ascribes the genus to the Cretaceous but apparently without sufficient grounds ; Bittner, $1875,{ }^{40}$ and Schlüter, $1879,{ }^{41}$ note that Palaeocorystes laevis of the Cretaceous is related to Raninoides, but do not place it in that genus.

\section{RANINOIDES VADERENSIS, new species}

Plate 22, fig. 5

Description.-Carapace very convex from side to side, gently so from front to back. Surface smooth and glossy to the naked eye, punctate, the punctae larger and crowded on the anterior two-fifths, becoming smaller and less crowded posteriorly almost to disappearance; however, everywhere there are widely scattered punctae of a larger size. Submedian grooves shallow; the outline of the carapace save for the spines is nearly oval. Lateral margin marked by a row of fine bead granules. Just below a band of larger granules. Antero-lateral spine narrow, projecting forward more than outward; the tips are broken off. Outer orbital spine narrow, acute, separated by a broad, shallow sinus from a much shorter spine; this in turn is separated by a deep $U$-shaped sinus from a broad, flattened, subacute spine. A narrower sinus lies between it and a much smaller spine; between this and the rostrum there is a broad arcuate margin. Rostrum with slightly convex, granulate margins and a median ridge.

A portion of the merus of the left cheliped is nearly circular in cross-section, and the surface finely rugose. A.t a short distance is an impression of what appears to be part of the manus ornamented with a reticulated pattern of fine granules.

Measurements.--Length of carapace of holotype $33 \mathrm{~mm}$.; greatest width of carapace near the middle $18.4 \mathrm{~mm}$.; width at posterior base of antero-lateral spines $16.8 \mathrm{~mm}$.; length of rostrum $2.6 \mathrm{~mm}$.; frontoorbital width $11.8 \mathrm{~mm}$.

Occurrence.-Washington: 1 mile west of junction of Olequa and Stillwater Creeks on the latter near Vader, Lewis County, in section 30, township 11 north, range 2 west; upper Eocene series, Tejon formation. One specimen showing dorsal surface of carapace and two fragments of appendages. Holotype in University of Washington.

Oregon: Western part, at "Basket Point" on Umpqua River, 12 miles below mouth of Calapooia River, Douglas County; middle Eocene series. One small specimen about $16 \mathrm{~mm}$. long, with a portion of the carapace exposed, showing posterior and one lateral margin with antero-lateral spine. Cat. No. 353355, U.S.N.M. 
Description.-Shape of carapace similar to that of $R$. vaderensis, but the anterior half is more oblong, the widest part in front of middle, the fronto-orbital width greater, the antero-lateral spine further forward, the lateral margin not so strongly outcurved behind the spine; postero-lateral margin straighter; the dorsal surface more convex, so that in dorsal view one can scarcely see the lateral margins. Very little of the outer layer of shell remains, it shows roughness near the antero-lateral margin; the layer just below is rough with fine granules in front which gradually diminish in size until the posterior end is nearly smooth. Merus of cheliped little more than twice as long as wide, outer margin very convex.

Measurements.-Holotype, length of carapace to posterior end of inner frontal sinus $28.3 \mathrm{~mm}$.; greatest width of same $19 \mathrm{~mm}$; width at posterior base of antero-lateral spines $17 \mathrm{~mm}$.; fronto-orbital width (tips of spines broken off) $13.5 \mathrm{~mm}$.

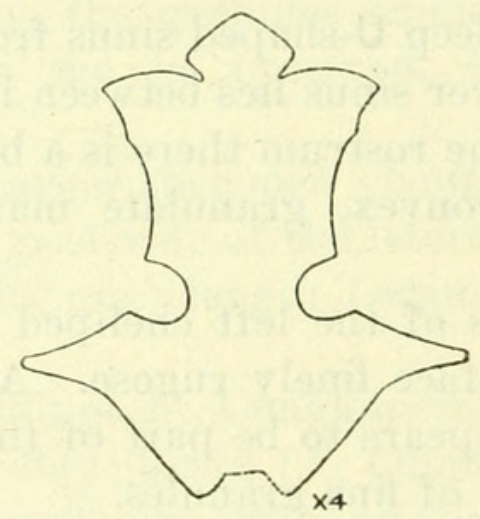

Fig. 3.-Raninoides dickersoni. Sternum (First and SECond SEgMents and episterNUM) OF HOLOTYPE, $\times 4$

Occurrence.-Washington: Railroad bluff about $1 \frac{1}{2}$ miles south of Vader, Lewis County, about 700 feet below railroad post No. 79, section 4, township 11 north, range 2 west; Eocene series; two specimens, one large holotype, one small paratype, in University of Washington.

RANINOIDES DICKERSONI, new species

Plate 20, fig. 5

Cancer (?), species $b$ Dickerson, Univ. California Publ. Geol., vol. 9, No. 17, 1916, pp. 427 and 434, pl. 42, fig. 12.

Description.-Greatest width of carapace $21.4 \mathrm{~mm}$. Carapace narrowed anteriorly; margin thick and bluntly rounded. Only one tooth evident behind the orbital tooth and not far from the latter; 
it is broken off at base but the fracture indicates that it was directed rather forward than outward. Lower surface of carapace granulate.

Episternum short, subtriangular, separated by a notch from the first somite. First sternal somite suboblong, anterior margin nearly transverse. Second somite anteriorly broader than the first.

Occurrence.- Southeast quarter of northwest quarter of section 15, on branch of Salt Creek, township 18 south, range 14 east, Mount Diablo base line and meridian, Coalinga quadrangle, Fresno County, California; middle Eocene series, near base of Tejon group, 75 to 100 feet above the chocolate shale of probable Chico age, in a glauconitic sandstone stratum in clay shale; one specimen showing portion of under surface, holotype, in University of California.

RANINOIDES WASHBURNEI, new species

Plate 22, fig. 6

Description.-Carapace less convex from side to side than in vaderensis. Surface everywhere punctate; punctae plainly seen without a lens, largest in the middle, where the narrow interspaces form a lacelike mesh. Submedian grooves emphasized by a small swelling on the outer or branchial side. The fronto-orbital space is wider than in vaderensis and the antero-lateral spine projects more outward than in that species. Outer orbital spine broad though incomplete, but the indications are that it is bispinous; the adjoining sinus inclines to a V-shape and the spine beyond it is similar to the corresponding one in vaderensis; there is another, deeper, oblong sinus and a third spine (broken off) either side of the rostrum; only the broad base of the latter is visible.

In the smaller concretion there are fragments of more than one appendage, including two articles which may be the terminal portion of the third or last swimming leg.

Measurements.-Length of carapace of holotype (estimated) 31 $\mathrm{mm}$.; greatest width, between tips of antero-lateral spines $22.2 \mathrm{~mm}$.; width half way back $20.7 \mathrm{~mm}$.; fronto-orbital width $14 \mathrm{~mm}$.

Occurrence.-Oregon: Near Eugene; upper Oligocene series; two small carapaces lacking spines may be young of $R$. washburnei; a fragment of a larger carapace is also doubtfully referred to this species.

Oregon; Western part, at "Basket Point" on Umpqua River, 12 miles below mouth of Calapooia River, Douglas County; middle Eocene series. One carapace in nodule (Cat. No. 353336, U.S.N.M.), holotype, and impression; fragments of appendages in another nodule, said to have occurred next the first one. 


\section{RANINOIDES EUGENENSIS, new species}

Plate 24, fig. 4

Description.-Carapace slightly convex from side to side, almost flat longitudinally on the median line. Surface coarsely punctate, similarly to $R$. washburnei, surface layer incomplete. The anterior spines are incomplete, but the two principal orbital spines are more advanced than the rostrum. Rostrum subacute, flanked on either side by a very short spine; the narrow sinuses appear to be $\mathbf{U}$-shaped, the intervening spine oblong, blunt, the outer spine broad but with details missing. The carapace is slightly constricted for a very short space behind the antero-lateral spines, so that the widest point is not far behind those spines. The postero-lateral margin though slightly convex is nearly straight.

Measurements.-Length of carapace of holotype, approximately $24.5 \mathrm{~mm}$.; width between tips of antero-lateral spines $17.7 \mathrm{~mm}$; greatest width behind the spines $14.8 \mathrm{~mm}$; fronto-orbital width $10 \mathrm{~mm}$.

Occurrence.-Oregon; near Eugene; upper Oligocene series; one carapace, holotype, and impression and portions of two other carapaces, one of which may be considered a paratype. Holotype in University of Oregon.

Oregon: Western part, one-fourth mile west of Springfield Junction on Southern Pacific Railroad, Lane County; Oligocene series. One carapace, incomplete and corroded but determinable by the nearly straight postero-lateral margin and the coarsely punctate surface, which is continued on at least the anterior part of the ventral surface of the carapace. The specimen is considerably larger than the type, measuring $22 \mathrm{~mm}$. in greatest width behind the spines; all spines are lacking. Cat. No. 353338, U.S.N.M.

Relation.-In its surface and antero-lateral spines this species resembles $R$. washburnei, but differs notably in its flatter and narrower carapace, more rapidly diminishing posteriorly.

RANINOIDES FULGIDUS, new species

Plate 23, fig. 6

Description.-Carapace very convex from side to side, rising steeply from the lateral margins in their middle third; gastric region a little convex longitudinally, carapace posteriorly flat. The punctae of the carapace are visible to the naked eye, are widely separated on ihe greater part of the carapace, but numerous and more or less crowded on the anterior and antero-lateral regions; the interspaces are filled with fine, scabrous granules which are most abundant and prominent where the punctae are most numerous; posterior end of carapace smooth, devoid of granules and punctae. Behind the outer 
margin of the outer spine or tooth of the orbit, the lateral margin of the carapace is arcuate, exclusive of the antero-lateral spine; the postero-lateral margin is nearly straight. The antero-lateral spine does not interrupt the general curve of the margin and projects sideways very little, if at all, beyond the line of that curve.

While the general character of the frontal outline is similar to that of the species described above, it differs from washburnei and eugenensis in this, that the outer of the two narrow sinuses reaches further backward than the inner, while in the other three species, the reverse is true. The tips of all the spines are wanting; the two outer spines incline toward the cylindrical, the outer one having a

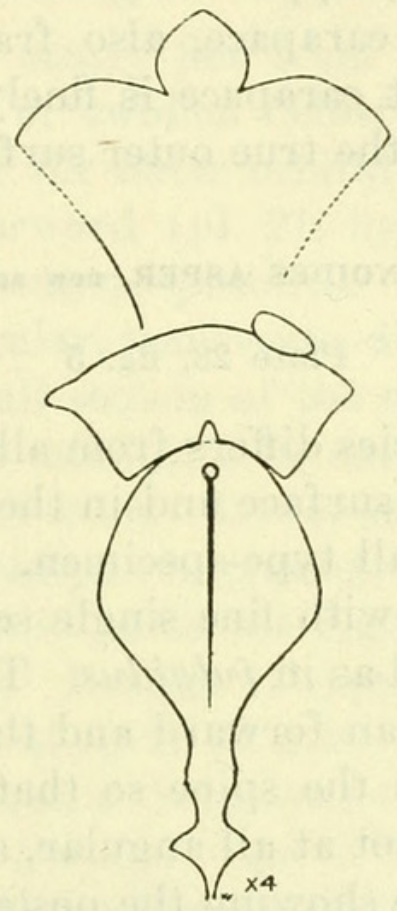

Fig. 4.-Raninodes fulgidus. Sternum (353339), $\times 4$; the First Segant and the EPISTERNUM ARE IN A SEPARATE PIECE OF ROCK FrOM THE REST AND PERHAPS BELONG TO A DIFFERENT SPECIMEN

small spine on its inner slope. The rostrum is broad and apparently shorter than the outer spines and is flanked on either side by a smaller tooth bordering the sinus.

Cheliped elongate, reaching considerably beyond the carapace; surface covered with scabrous granules which are rougher on manus than on merus. Apparently a spine has been broken from the upper margin of the manus at its distal third.

This species can always be distinguished by the ornamentation of the carapace, consisting of punctae and fine granules in combination.

Measurements.-Estimated length of carapace of holotype 43.3 $\mathrm{mm}$.; greatest width, in front of middle, $24.3 \mathrm{~mm}$.; estimated width of front and orbits $20 \mathrm{~mm}$.; length of upper margin of palm $13 \mathrm{~mm}$. 
Occurrence.-Oregon: Springfield Junction, 1 mile west of Springfield, Lane County; Oligocene series; three specimens and one impression of parts of the carapace; also two specimens showing together the episternum and the first three sternal somites. Cat. No. 353340, U.S.N.M.

Oregon: Western part, one-fourth mile west of Springfield Junction, Southern Pacific Railroad, Lane County; Oligocene series. Six specimens, more or less defective, showing the dorsal side of the carapace and in one case, three segments of the sternum. The largest one which has also some pieces of the chelipeds is made the holotype; Cat. No. 353339, U.S.N.M.

Oregon: Near Eugene; upper Oligocene series; three specimens and two impressions of carapace, also fragments of sternum and appendages. The largest carapace is finely granulate and dull all over, but does not retain the true outer surface which is shining and partly smooth.

\section{RANINOIDES ASPER, new species}

Plate 23, fig. 5

Description.-This species differs from all those above described in the ornamentation of the surface and in the character of the anterolateral spine. In the small type-specimen, which is brown in color, the surface is roughened with fine single scabrous granules without large punctae interspersed as in fulgidus. The antero-lateral spine is directed more outward than forward and the margins on either side curve rapidly away from the spine so that the sinuses formed are very broad and shallow, not at all angular, as they are in americana.

A fragment of carapace showing the posterior left corner is nearly black; it belonged to a larger specimen than the type but has the same asperities besides a posterior and postero-lateral rim of very fine granules.

A third specimen exposes a part of the merus and carpus of the right cheliped. Most of the outer surface layer is lacking, but there are indications of fine rugose lines. The merus is strongly curved and very stout.

A fourth specimen contains several small fragments of carapace crushed together with no means of identification except the characteristic surface.

Occurrence.-Oregon: Western part, at Springfield Junction, one mile west of Springfield, Lane County; Oligocene series. Four fragments of carapace and appendages; the fragment showing the anterolateral spine and adjacent part of the carapace may be considered the type; Cat. No. 353337, U.S.N.M. 


\section{Genus RANIDINA Bittner}

Ranidina BittNer, Sitzungsber. Kais. Akad. Wiss., Wien, math.-naturw. Cl., vol. 102, Abth. 1, 1893, p. 33 ; type, $R$. rosaliae Bittner.

Anterior margin of carapace narrow, with three triangular teeth including rostrum; thence the carapace widens rapidly to a large lateral tooth about one-third the distance to the narrow posterior margin. Sternum broad between feet of first and second pairs.

Oligocene; Miocene.

\section{RANIDINA WILLAPENSIS, new species}

Plate 21, figs. 4 and 5

Description.-Carapace nearly flat from side to side except near the margin; very convex or swollen below (pl. 21, fig. 4). Shape suboval up to the base of the outer orbital spine which is directed obliquely outward and forward (pl. 21, fig. 5) ; fronto-orbital distance narrow, details obscured; posterior margin much narrower. Lateral spine stout, triangular, transverse, directed obliquely upward and outward. Only a small section of the outer surface of the shell remains, behind the right middle; it is covered with large punctae near together forming a net work. Lower surface coarsely granulate.

Measurements.-The holotype is cracked obliquely longitudinally through the middle and also lacks the right margin, so that measurements are approximate. Length of carapace $47.4 \mathrm{~mm}$.; width of same just in front of lateral spine $32 \mathrm{~mm}$.; distance on median line between the front margin and a line drawn between the lateral spines $18 \mathrm{~mm}$.; distance between (broken) tips of lateral spine and of outer spine of orbit $17 \mathrm{~mm}$; distance from tip of lateral spine to posterior margin $35.3 \mathrm{~mm}$.; greatest thickness of carapace $14 \mathrm{~mm}$.

Occurrence.-Washington: Tuffaceous sandstone bluffs along the Willapa River, north of Holcomb; middle Oligocene series. One specimen, holotype, showing the dorsal surface of the carapace incompletely and a portion of the right ventral surface; in Stanford University.

Washington: Sea cliffs between Classens Wharf and the ship canal estuary, Townsend Bay; lower Oligocene series; one specimen showing the left side of the ventral surface of the carapace. Its identity is made reasonably certain by its great breadth and the character of the surface.

Relation.-From $R$. rosaliae Bittner ${ }^{42}$ from the Miocene of Hungary our species differs in its smoother surface, and inward-pointing orbital spine.

42 Sitzungsber. k. Akad. Wiss., math.-naturw. Cl., Wien, vol. 102, Abth. 1, 1893, p. 33. 


\section{Genus EUMORPHOCORYSTES von Binkhorst}

Eumorphocorystes von BinkhoRst, Rheinlande u. Westphal. naturh. Verein. Verh., vol. 14, 1857, p. 108; type, E. sculptus Binkhorst.

Carapace very convex, egg-shaped, divided into two symmetrical parts by a raised median line which ends anteriorly in a small point; one marginal tooth on either side placed well forward. Buccal cavity elongated in a pointed arch and extending nearly half the length of the carapace. Sternal surface not known.

Cretaceous; Oligocene.

\section{EUMORPHOCORYSTES NASELENSIS, new species}

\section{Plate 24, figs. 9 and 10}

Description.-Carapace very convex in both directions but most so from side to side, suggesting half an egg (pl. 24, fig. 10) ; widest at lateral spine which is situated in advance of the anterior third; postero-lateral margin rounding gradually into posterior margin without an angle (pl. 24, fig. 9) ; antero-lateral margin becoming concave soon after leaving the lateral spine and continuing to the orbital angle, the outer spine directed inward. The anterior margin in front view arches upward; it appears to have three sinuses on tho right side; the rostrum is not uncovered. A high blunt median ridge the length of the carapace. The surface is covered with large, unequal and adjacent punctae separated by a coarse network. Lateral margin finely granulated. The lateral spine (pl. 24, fig. 10s) seems to have pointed a little forward.

Measurements.-Length of carapace (approximate) $53.6 \mathrm{~mm}$; width behind lateral spine $39.3 \mathrm{~mm}$. Distance from middle of base of lateral spine (broken off at base) to outer angle of orbit $19 \mathrm{~mm}$; distance from same point to middle of posterior margin $43.7 \mathrm{~mm}$; width of front and orbits $16.2 \mathrm{~mm}$; greatest height of carapace above lateral margin $13.2 \mathrm{~mm}$.

Occurrence.-Washington: Shale bluffs along Nasel River near mouth of Salmon Creek, Nasel; middle Oligocene (?) series. One specimen showing little more than half of dorsal surface of carapace.

Relation.-This species has much in common with the preceding, Ranidina willapensis: A similar outline and ornamentation, one stout lateral spine, a narrow front and rear and a thick body. It differs in having the dorsal surface much more convex, in the presence of a median ridge, in the lateral spine being nearer the front, in the front narrower and the outer orbital spine inclined inward instead of outward. 
On account of the egg-shaped body, the median ridge and the narrow fissures of the anterior margin, I place the species in Eumorphocorystes Binkhorst ${ }^{43}$ described from a species, E. sculptus, from the Chalk of Maestricht.

\section{Genus PALAEOCORYSTES Bell}

Palaeocorystes Bell, Monog. Fossil Malac. Crust. Great Britain, 1862 (1863), p. 11; type, P. broderipii Mantell.

Carapace depressed, becoming gradually narrower posteriorly, antero-lateral margin dentate, rostrum bifid, orbit bifissured above. Buccal cavity subtriangular, narrowing slightly anteriorly. First thoracic sternite narrowing toward the front and expanding laterally toward the back. Episternum trilobed. Second sternite shorter than first or third, widening from front to back. Third sternite longer and narrower than second, fourth narrows equally, its length nearly half less than third.

Cretaceous; Eocene.

\section{PALAEOCORYSTES HARVEYI Woodward}

Plate 20, fig. 4

Palaeocorystes harveyi Woodwand, Quart. Journ. Geol. Soc. London, vol. 52, 1896, p. 225, text-fig. 4.-Whiteaves, Mesozoic fossils, vol. 1, pt. 5; Geol. Surv. Canada, Ottawa, 1903, p. 317, text-fig. 17.

Type-localities.-British Columbia: Hornby Island and Comox River, Vancouver Island. Cretaceous. Types in Provincial Museum, Victoria, and Museum of the Geological Survey, Ottawa.

\section{Tribe ANOMURA Milne Edwards}

\section{Superfamily PAGURIDEA Dana \\ Family PAGURIDAE Boas}

HERMIT CRABS

Abdomen soft, showing no trace of segmentation, straight, twisted, or spirally coiled; some of the appendages lost, the remainder much reduced; tail-fan not adapted for swimming but for holding body in hollow objects. Carapace firm in fore part and soft in hind part. First pair of legs chelate; fourth pair unlike third.

\section{Genus PAGURISTES Dana}

Paguristes Dana, U. S. Expl. Exped., vol. 13, Crustacea, pt. 1, 1852, p. 436 ; type, $P$. hirtus Dana.

Chelipeds similar, equal, subequal or one (usually the left) may be larger than the other. Fourth pair of legs simple. Outer maxil-

${ }^{43}$ Rheinlande u. Westphal. naturh. Verein. Verh., Bonn, vol. 14, 1857, p. 108, pl. 7 (not 6). 
lipeds approximated at base. Abdomen with paired appendages other than the uropods on the first two segments in the male and the first segment in the female.

Miocene (?); Recent.

\section{PAGURISTES, species}

Plate 24, fig. 3

Description.-The specimen as well as its encasing rock is so crumbly that no more can be uncovered without destroying it. Only the form of the fingers is seen and in the case of the propodal finger nothing but the impression. The fingers meet along their prehensile edges which are dentate and longitudinal or nearly so. The outer part of the proximal third of each finger is broken away; the distal two-thirds gradually diminishes, with the outer margins slightly convex. The propodal finger appears triangular in crosssection; its lower surface is granulate along the inner and outer edges. The distance across the fingers at the proximal third is $10.6 \mathrm{~mm}$. A fragment of the inner surface of the palm bears several tubercles.

Occurrence.-California : Santa Rosa quadrangle, Sonoma County; 1 mile south of Mountain School and 11/2 miles southwest of Petaluma Reservoir, on right bank of creek bed; Miocene (?) series, fresh and brackish water zone; one specimen, showing part of the right cheliped.

Relation.-Approaches $P$. turgidus (Stimpson) ${ }^{44}$ a Recent species on the coast from British Columbia to San Diego and extending down to 254 fathoms. The fingers of the fossil are more nearly equal.

\section{Genus DARDANUS Paulson}

Dardamis Paulson, Invest. Crabs Red Sea, Kiev, 1875, p. 90 ; type, $D$. hellerii Paulson.

Chelipeds with few exceptions dissimilar and unequal, the left being much the larger; finger tips corneous, blackened and somewhat spooned, especially those of smaller hand. Fourth pair of legs subchelate. Outer maxillipeds approximated at base. No paired appendages on anterior abdominal segments of either sex.

Eocene; Pleistocene; Recent.

DARDANUS SUBAEQUALIS, new species

Plate 24, figs. 1 and 2

Description.-Chelae similar and subequal. In the left or major chela (pl. 24, fig. 2) the palm is only slightly higher than in the right ( $\mathrm{pl} .24$, fig. 1), and seemingly shorter, the fingers are longer

4 Schmitt, Univ. California Publ. Zoöl., vol. 23, 1921, p. 123, pl. 18, figs. 1 and 8. 
than in the left chela where they are largely broken away. The outer surface of the palms is strongly convex from the upper to the lower margins, slightly so from end to end; on the upper two-thirds there are five rows of stout, spaced tubercles or blunt spines. The upper row is marginal, the lowest of the five is prolonged feebly on the fixed finger; the upper and lower interspaces are narrow, the others wide, the second, counting from the top, widest; the upper interspace forms the upper surface of the palm. The lower margin is marked by a row of similar tubercles, and above it is a partial row. The remainder of the outer surface is deeply reticulated, with indications of low tubercles at the principal intersections of ridges. Immovable finger elongate triangular, very high at base. Dactylus thick in top view, showing four irregular rows of tubercles.

Right palm similar to left but a little lower and longer; distally it is still lower as the outer surface there turns abruptly inward forming a lower surface.

Upper edge of merus of cheliped tuberculate, lower edge slightly imbricate; outer surface largely covered with short, deeply impressed lines.

Measurements.-Holotype, greatest height of right palm $12.4 \mathrm{~mm}$., superior length of same $12.4 \mathrm{~mm}$; greatest height of left palm 13 $\mathrm{mm}$., superior length of same $10 \mathrm{~mm}$., inferior length of palm and immovable finger $21.6 \mathrm{~mm}$., basal height of latter $7.8 \mathrm{~mm}$., superior length of dactylus $13.7 \mathrm{~mm}$., extreme height of merus $8.8 \mathrm{~mm}$.

Occurrence.-California : vicinity of La Jolla; Eocene series; one specimen, showing the two chelae of a single individual, side by side; below the left palm is the greater portion of the merus, the cheliped having been bent on itself at the middle. Holotype in University of California.

Relation.-In most Recent species of the genus Dardanus the left cheliped is larger than the right, but seldom are the two so nearly of a size as in this species. In D. hessii (Miers) ${ }^{45}$ for instance, the chelae are nearly or quite equal but much smaller and narrower than in our species. The ornamentation of $D$. subaequalis is akin to that of the Japanese $D$. impressus (de Haan), ${ }^{46}$ but here the armature consists of sharp-pointed spines instead of blunt tubercles and the chelipeds are very unequal. None of the species now living on the American coast resembles this Eocene species.

DARDANUS ARNOLDI, new species

Plate 24, figs. 5-8

Description.-Dactylus: Two longitudinal rows of spines (pl. 24, fig. 6), one on outer margin, the other on middle of upper side;

${ }^{45}$ Pagurus hessii Miers, Zoöl. Alert, 1884, pp. 185 and 264, pl. 28, fig. A.

${ }^{46}$ Pagurus impressus de Haan, Fauna Japon., Crust., 1849, p. 207, pl. 49, fig. 3. 
spines stout, conical, blunt, directed obliquely distad, nine in each row, diminishing in size toward tip of finger. Upper and lower surfaces (pl. 24, fig. 5 and 6) covered with large spaced granules, larger at proximal end; some of them show a hair-socket. Two low, prehensile teeth, the basal one very large, subcircular, the next tooth touching the first and much smaller, broader than long. Finger slightly curved inward toward tip, prehensile surface hollowed out in middle third.

Wrist: The wrist belongs to a smaller cheliped than the dactylus. Upper margin pronounced, armed with a single row of 15 spines which increase in size toward distal end with exception of two small spines on articulating condyle, and have on the outer side of each a socket for hairs. Just below this row on the inner side and nearly parallel but diverging a little distally, there is row of flattened tubercles directed upward and with an elongate orifice in the top of each. Further down the inner surface (pl. 24, fig. 8) is covered with similar flattened, striated tubercles directed obliquely upward and distad and equipped each with a similar orifice. On the lower, short part and also on the distal part of this surface there are simple oblique striations which terminate along the distal edge in a row of granules. The ornamentation of this surface resembles a colony of encrusting bryozoans. Outer surface (pl. 24, fig. 7) rougher, armed with fifteen or more short, upstanding, conical spines or tubercles each with a socket on upper side; the intervening space is filled with granules, some of which also are provided with hair sockets.

Measurements.-Length of right movable finger, holotype (a short piece missing from either end), $7.3 \mathrm{~mm}$. Length of right wrist, paratype (chord of outer margin), $5.1 \mathrm{~mm}$.

Occurrence-California: Rincon del Potrero, Santa Monica; Pleistocene series; one left wrist or carpus of cheliped, paratype; Cat. No. 353568, U.S.N.M.

California: Deadman Island, southeast of San Pedro; Pleistocene series; one right movable finger or dactylus, holotype; in Stanford University.

Relation.-In shape the dactyl approaches that of $D$. impressus (de Haan), ${ }^{47}$ but the ornamentation is very different, impressus having four rows of acorn-shaped tubercles. While it is not certain that wrist and hand belong to the same species, there is a strong probability that they do. Both have the Dardanus form, were found in the same horizon and geographically not far apart. There is sufficient similarity in their ornamentation.

$D$. arnoldi is not akin to the Recent Californian species, D. jordani. ${ }^{48}$ In $D$. subaequatis, described above, the chelae are subequal

${ }^{47}$ Pagurus impressus de Haan, Fauna Japon., Crust., 1849, p. 207, pl. 49, fig. 3.

4 Schmitt, Univ. California Publ. Zoöl., vol. 23, 1921, p. 126, pl. 17, figs. 3 and 4. 
and similar; in $D$. arnoldi the same may be true, as the movable finger of the right cheliped, which in this genus is the smaller, has the appearance of a major dactylus.

\section{Genus PAGURUS Fabricius}

Pagvrvs FABRicius, Syst. Entom., 1775, p. 410; type, P. bernhardus (Linnaeus).

Chelipeds usually dissimilar and unequal, the right being much the larger; very rarely subequal. Fourth pair of legs subchelate. Outer maxillipeds widely separated at base. No paired appendages except the uropods, on the abdomen of either sex.

Pleistocene; Recent.

\section{PAgURUS GRANOSIMANUS (Stimpson)}

Eupagurus granosimanus Stimpson, Ann. Lyc. Nat. Hist. New York, vol. 7, 1862, p. 90.

Pagurus granosimanus ScHмiтт, Univ. California Publ. Zoöl., vol. 23, 1921, p. 141, text-fig. 91 and synonymy.

Description.-These specimens agree with Recent ones of this today widely distributed species (Unalaska to Lower California). Surface covered with rather closely placed, slightly forward-pointing granules, with some smaller granules in the interstices. The granules of the outer marginal row are larger and have the appearance of thick, blunt serrations.

Occurrence.-California; Pleistocene :

Nob Hill (lumber yard), northeast of San Pedro; lower San Pedro formation; one right immovable finger; Cat. No. 353353, U.S.N.M.

Deadman Island, southeast of San Pedro; one propodus of right cheliped.

\section{Superfamily THALASSINIDEA Ortmann}

\section{Family CALLIANASSIDAE Bate}

Body shrimplike. Abdomen extended; abdominal pleura small or absent; tail-fan well developed and adapted for swimming. First pair of legs unequal or subequal, perfectly or imperfectly chelate; third and fourth pairs simple, others variable. Antennal peduncle five-jointed; antennal scale quite vestigial; no antennal thorn.

\section{Genus CALLIANASSA Leach}

Callianassa LeACH, Edin. Encyc., vol. 7, 1814, p. 400; type, C. subterranea (Montagu).

First pair of legs very unequal, with well developed, much compressed chelae; second pair small and chelate; fifth pair subchelate. 
Eyestalks triangular or oblong, flattened; cornea dorsal, median, small or absent. Rostrum short, triangular, rudimentary or absent. Jurassic; Cretaceous; Eocene; Oligocene; Miocene; Pleistocene; Recent.

This genus occurs from the Lias down to Recent. About 90 fossil species have been described and 78 Recent. Five species are now living on the west coast of America ; only one of these, $C$. goniophthalma, from deep water, 192 to 322 fathoms, has the large tubercles or raised sockets for hairs on the outer surface of the palm such as are present on 5 of the 12 fossil species described below from the manus. $C$. longimana is the Recent species which in its elongate wrist and palm approaches $C$. oregonensis of the Miocene.

KEY TO THE FOSSIL SPECIES OF THE GeNUS CALLIANASSA ON THE PACIFIC SLOPE OF NORTH AMERICA

\section{Species in whick the manus is known}

$A^{1}$. Manus with the whole or a portion of its outer surface roughened with tubercles.

$\mathbf{B}^{1}$. Tubercles scattered over outer surface of manus; distant, not large. Manus short, with a hollow at distal end of outer surface. Propodal finger very long, much longer than hand.

bandonensis (Oligocene), p. 118.

$B^{2}$. Tubercles restricted to lower half of outer surface of manus.

$\mathrm{C}^{1}$. Tubercles occupying greater part of lower half of outer surface of manus; upper and lower margins dentate; proximal margin oblique__._.

$\mathrm{C}^{2}$. Tubercles confined mostly to the lower distal quarter of outer surface of manus.

$D^{1}$. Fingers equally wide at base, not gaping. Upper and lower margins of palm diverging distally in male. Tubercles elongate_-_-_

$\mathrm{D}^{2}$. Dactylus broader at base than fixed finger; fingers separated at base; a spine or tubercle on palm in gape between fingers.

$\mathrm{E}^{1}$. Palm elongate; proximal margin oblique.

$E^{2}$. Palm shorter; proximal margin vertical.

knapptonensis (Eocene), p. 112.

clallamensis (Oligocene), p. 114.

$A^{2}$. Manus with its outer surface smooth (or nearly so).

$B^{1}$. Manus with a large backward-pointing tooth on upper proximal corner and another tooth in gape close to dactylus.

$\mathrm{B}^{2}$. Manus without a large backward-pointing tooth on upper proximal
corner.

$C^{1}$. Manus broader than long.

$D^{1}$. Propodal finger occupying half the height of distal end of palm.

incerta (Eocene), p. 108.

$\mathrm{D}^{2}$. Propodal finger occupying not more than a fourth the height of distal end of palm.-.

¿o Outer layer of shell not preserved. 
$C^{2}$. Manus longer than broad.

$D^{1}$. Upper surface of manus broadly rounded, without a marginal line; cross-section broad-oval__________-_fresnoensis (Eocene), p. 109.

$D^{2}$. Upper surface of manus with a definite, more or lass acute, margin. $\mathbf{E}^{1}$. Dactylus broader than fixed finger, their bases separated by a gape into which projects from the manus a broad shallow lobe composed of two lobules, the lower lobule having a denticulate margin_-_-_-_-_porterensis (Oligocene), p. 119.

$\mathrm{E}^{2}$. Dactylus and fixed finger of equal or nearly equal width; gape narrow or absent.

$\mathrm{F}^{1}$. Carpus, or wrist, short, broader than long.

whiteavesii (Cretaceous), p. 107.

$\mathbf{F}^{2}$. Carpus elongate, longer than broad.

$\mathrm{G}^{1}$. Socket-bearing tubercles of fingers prominent.

oregonensis (Oligocene, probably), p. 121.

$\mathrm{G}^{2}$. Sockets sunk below surface of fingers. A tooth on proximal half of each finger.

longimana (Pleistocene and Recent), p. 122.

$\mathbf{A}^{3}$. Manus irregularly and minutely wrinkled. (Not seen by present writer).

stimpsonii ${ }^{50}$ (Eocene), p. 107.

Species in which only the fingers are known

Fingers without a prehensile lobe or tooth_-_-_stephensi (Pleistocene), p. 122.

CALLIANASSA WHITEAVESII Woodward

Plate 20, figs. $6-8$

Callianassa whiteavesii Woodwand, Quart. Journ. Geol. Soc. London, vol. 52, 1896, p. 223, text-figs. 1 and 2; Geol. Mag., n. s., dec. 4, vol. 7, 1900, p. 435 , pl. 17, fig. $2 a$, b.-Whiteaves, Mesozoic fossils, vol. 1, pt. 5; Geol. Sur. Canada, Ottawa, 1903, p. 319, text-figs. 18 and 19.

Occurrence.-British Columbia: Comox River, Vancouver Island; Cretaceous (type-locality); types (pl. 20, figs. 6 and 7) in Museum of the Geological Survey, Ottawa.

Northwest Territory: Township 30, range 8, west of fourth principal meridian; Cretaceous (Woodward). (See pl. 20, figs. $8 a$ and 8b.)

Figure $8 b$, plate 20 , apparently represents the normal length of the immovable finger.

\section{CALLIANASSA STIMPSONII Gabb}

Callianassa stimpsonii GABB, Palaeontology of California, vol. 1, sec. 4, 1864 , p. 57 , pl. 9 , fig. $1, a, b$, ; vol. 2 , sec. 2,1869 , p. 127 , pl. 19 , fig. 3 (correction of pl. 9, fig. 1 b) ; Proc. California Acad. Sci., vol. 3, 1867, p. 302 (type-localities, California : "Chico Creek, Chico Group, Upper Cretaceous series ; Clayton and Canada de las Uvas, Tejon ${ }^{51}$ Group," Eocene series (Cretaceous of Gabb).-Herlprin, Proc. Acad. Nat. Sci. Phila., vol. 34, 1882, p. 197.-Cooper, California State Mineralogist, 7th Ann. Rept., 1887 (1888), p. 271.

"Hand subquadrate, flattened, equally convex on both sides, slightly twisted. Upper and lower edges acute; the lower one crenu-

${ }^{50}$ Not $C$. stimpsoni Smith, 1873 , Recent, which may be known as $C$. atlantica, new name.

${ }^{11}$ Dr. G. Dallas Hanna says in a letter, "It seems doubtful if any of Gabb's material came from the type section of the Tejon although the species was reported from there." 
late. Fixed finger (from cast) nearly as long as the hand, not toothed, very slightly curved on its inner edge. Movable finger unknown. Surface irregularly and minutely wrinkled, and marked along the upper edge by a row of about seven foramina, surrounded by a raised lip looking forward, and over the rest of the surface by a number of pustules, which are largest and most closely placed on the upper half" (Gabb).

It is impossible to determine the status of this species without seeing the specimens figured by Gabb. These are apparently not extant. A lot of five specimens collected by Gabb and labeled "Callianassa stimpsonii" has been loaned to the writer by the Philadelphia Academy of Natural Sciences through Dr. H. A. Pilsbry. It bears the labels "Clayton" and "Martinez." None of the five answers to the description or figures of $C$. stimpsonii; two (wrist and hand) represent another species of Callianassa, two are crab claws, while the fifth is the carapace of an undetermined shrimp.

CALliANASSA INCERTA, new species

Plate 25, figs. 1-4

Among the specimens borrowed from the Academy of Natural Sciences, Philadelphia, under the name, Callianassa stimpsonii Gabb, are two specimens of Callianassa of a different species; they are labeled "Martinez" and "Clayton," and are Eocene. Right manus, holotype, and left carpus or wrist, paratype.

Description.-Manus: Proximal margin concave, upper margin convex, lower straight except where it curves upward at the proximal end (pl. 25, fig. 1). Outer surface very convex in a vertical direction, inner surface slightly convex, upper and lower margins thin, edge acute (pl. 25, fig. 3). The cavity for insertion of dactylus equals half the height of distal end of manus and meets the stump of propodal finger. This is thin, prehensile edge sharp, bearing a broad triangular tooth; inner surface (pl. 25, fig. 2) divided by a longitudinally oblique ridge into two surfaces the upper of which is concave. Outer layer of shell lacking, exposed layer covered with low transverse reticulations; upper distal corner of outer surface slightly roughened with oblong granules.

Carpus (pl. 25, fig. 4) : Embedded in rock. Like the hand, very convex externally, upper and lower margins turned strongly inward. Surface nearly smooth, with indications of oblong granules on the middle third of the lower half.

Measurements.-Length of manus to suture $8.5 \mathrm{~mm}$., greatest height, near proximal end $9 \mathrm{~mm}$., distal height $7.5 \mathrm{~mm}$. Length of wrist $6.5 \mathrm{~mm}$., height $7.3 \mathrm{~mm}$. 
Description.-Proximal end of manus (pl. 25, fig. 5) nearly at right angles to lower margin, upper margin convex and converging toward lower margin at distal end. Outer surface very convex between the acute upper and lower margins, immovable finger bent strongly inward (pl. 25, fig. 7). Inner surface in great part convex both longitudinally and transversely, except above the lower edge where there is an elongate hollow leading back from the finger (pl. 25 , fig. 6). Just below upper margin and just above lower margin on outer surface a row of about 12 sockets. Lower margin bluntly serrated, a small socket in each interval. On the outer surface are several scattered punctae not far above the lower margin, also a few (four) at distal end behind and above the sinus. On the inner surface are two sockets obliquely placed behind the sinus.

Measurements.-Right manus, holotype, length measured from sinus between fingers $15.3 \mathrm{~mm}$., width near proximal end $17.5 \mathrm{~mm}$., width at distal end $15.7 \mathrm{~mm}$., greatest thickness $8.4 \mathrm{~mm}$.

Occurrence.-California : Carrizo Creek, Alverson Canyon, Coyote Mountain, Imperial County; Pliocene series; five specimens of manus, two right, three left, two having the base of the fixed finger attached. Holotype in University of California.

CALLIANASSA FRESNOENSIS, new species

Plate 26, figs. 4 and 5

Description.-Upper and lower margins thick, bluntly rounded (pl. 26, fig. 4) ; upper margin straight, lower margin sinuous, proximal margin oblique to upper (pl. 26, fig. 5). Inner and outer surfaces equally convex, the convexity rather uniform from one end to the other. Margins marked with two rows of punctae or hair sockets; one row is along middle of upper margin, the other on the outer surface; rows irregular, in the main nearer together than are the individual sockets in each row. Six sockets are visible in each row above. On the lower margin the rows are nearer together, one row along the middle, the other toward the inner surface. Both inner and outer surfaces have a number of distant punctae; on lower half of inner surface they form two rows of five each.

Measurements.-Approximate length of manus through middle 12 $\mathrm{mm}$., greatest width, toward proximal end, $7.3 \mathrm{~mm}$., width at distal end $7 \mathrm{~mm}$., thickness $4.5 \mathrm{~mm}$., greatest diameter of fixed finger near its origin $2 \mathrm{~mm}$.

Occurrence.-California: 1 mile southeast of Oil City, Fresno County; Eocene series (called Tejon by Arnold); one specimen of the left manus, holotype, in California Academy of Sciences. 
Manus.-Outer surface (pl. 25, figs. 10 and 12) very convex from top to bottom especially in upper half; nearly level from front to back except near the ends. Inner surface (pl. 25, fig. 11) much less convex and unevenly so. Proximal margin slightly oblique to the upper and lower margins which are subparallel to each other, so that the upper angle is slightly acutangular, the lower one obtusangular. Upper and lower margins drawn to a thin edge, the upper edge armed with from 9 to 11 saw teeth directed distad, each tooth tipped with a short curved spine at the end of a sharp ridge, (pl. 25, fig. 11 ), and having a spreading base enclosing a socket from which proceeded probably a bunch of hairs; an acute oblique ridge defines the sockets on the inner surface. The lower edge bears smaller and more numerous serrations, 14 appearing on each of three specimens, exclusive of the proximal corner; these teeth also embrace sockets and terminate in short curved spines, but they are connected on the outer surface with a smooth continuous ridge, and show no especial feature on the inner surface.

The lower half of the outer surface is occupied largely by a group of 30 or more irregularly disposed tubercles situated midway between carpus and fingers (pl. 25, figs. 10 and 12). A row of several tubercles subparallels the proximal margin, the largest tubercle situated at the lower two-fifths or one-third. On the inner surface (pl. 25, fig. 11) there is a group of tubercles similar to that on the outside but composed of fewer tubercles; also near the distal, upper corner a series of wrinkles. The smooth surface both inside and out shows a few punctae and also obscure, elongate tubercles which appear to be in a substratum of shell.

Fingers.-The propodal or fixed finger (pl. 25, fig. 12) is curved gradually upward from the lower line of the manus. It is subtriangular in cross-section, thickest near the top, the outer ridge smoothly rounded, the oblique upper surface marked by a line of a few very large punctae, the oblique lower outer surface by two rows of smaller and more numerous punctae which are continued on the palm; prehensile edge finely cremulate.

The dactylus (pl. 25, fig. 8) or movable finger (5455 and 324) is very thick except for a thin upper edge; the surfaces above and below the smooth inner ridge have a few punctae; the outer surface has a line of punctae on each margin; on the prehensile edge near the base there is a stout tooth. The two fingers have the appearance of fitting close together when shut. 
Minor chela.-Three smaller propodites (5455) with finger attached appear to be narrower and smoother than those above described. They may represent the minor chela.

Wrist.-One specimen about $21 \mathrm{~mm}$. long by 15 wide has the shape of a major carpus (pl. 25, fig. 9). The small piece of the outer shell visible is smooth. The inner shell is solidly covered with small, interlacing raised rings or half rings, in some of which there is a tubercle. The convexity of the article is similar to that of the manus.

Arm.-Two narrower, suboval pieces resemble in shape the minor merus of the first pereiopod. The surface of an inner layer of the larger specimen is covered with low oblong tubercles placed close together. The smaller specimen shows a smooth outer layer with dark mottlings.

Measurements.-Right propodus of cheliped, holotype, length measured from upper base of finger directly back, $16 \mathrm{~mm}$., greatest height $15.7 \mathrm{~mm}$., superior length $17.2 \mathrm{~mm}$., length of finger, tip lacking, $11 \mathrm{~mm}$. Right manus (237), length measured from upper base of finger directly back, $15.4 \mathrm{~mm}$., greatest height $17.6 \mathrm{~mm}$.

Occurrence.-Washington, Oregon; Eocene.

\section{WASHINGTON}

Olequa Creek, one-fourth mile above Vader Station, Lewis County, in east bank, just north of where small creek enters Olequa on east; section 29, township 11 north, range 2 west; six specimens of the right manus and one of the left.

West bank of Olequa Creek about one-eighth mile north of Vader Station; section 29, township 11 north, range 2 west; 9 specimens of the right manus, 13 of the left manus ( 1 with finger), 2 movable fingers and a fragment of the abdomen showing 4 segments.

Railroad bluff about $1 \frac{1}{2}$ miles south of Vader, about 700 feet below railroad post No. 79 ; section 4, township 11 north, range 2 west; 7 specimens of the right manus and 8 of the left.

Rock bluff in Northern Pacific Railway cut 2,850 feet south of mile post 76 and three-fourths mile north of Olequa railway station; upper Eocene or Tejon; three specimens of the right manus and one of the left.

WESTERN OREGON

Basket Point, on Umpqua River, about 12 miles below mouth of Calapooia River; middle Eocene series. Propodus (palm and finger) of right cheliped, holotype; also 8 additional specimens of the propodus, one of the carpus, and two of the merus. Holotype, Cat. No. 353328, U.S.N.M. 
Propodus of major cheliped.-Outer surface only is exposed. Manus very convex in a vertical direction, more so in the upper half where it curves over almost horizontally. Proximal margin slightly oblique to the upper and lower margins and rounded broadly into them; lower margin the less produced proximally, nearly horizontal, but slightly sinuous, making a slight bay under the distal half of the palm, and again curving obliquely upward from the base to the tip of the finger; upper margin of manus slightly convex, the distal half sloping considerably downward, so that the manus is lower at the distal end than elsewhere. (See measurements.) The lower margin forms a thin rim, widest at the proximal end, and marked with a row of punctae just above the edge; upper margin less prominent, with a few spaced tubercles.

The lower half of the outer surface is partially tuberculate, the tubercles concentrated in the distal lower corner, encroaching a little on the finger while a few of the smallest ones reach down to the marginal punctae. There are about 15 of the larger tubercles; the five uppermost ones are in a nearly horizontal row, beginning below the middle of the manus near its distal margin and ending at the proximal third.

The propodal finger occupies less than a third of the distal end of the manus, its occludent margin is concave and entire. Above its base a small, conical, sharp tooth projects from the manus distad into the interdigital gap. Dactylus not preserved. The articulating condyle of the manus lies half way between the upper margin and the base of the tooth in the gap.

Paratype.-Smaller than holotype, finger incomplete, surface imperfect. Agrees with the description of the holotype.

Measurements.-Holotype, right and larger propodus, length from proximal end above lower margin to upper proximal end of finger $19.4 \mathrm{~mm}$., total length measured to tip of finger $26.5 \mathrm{~mm}$., greatest height $16.3 \mathrm{~mm}$., least height, just behind fingers $15 \mathrm{~mm}$. Paratype, right manus, length from proximal end above lower margin to upper proximal end of finger $16.4 \mathrm{~mm}$., greatest height $12.6 \mathrm{~mm}$., least height, just behind finger $11 \mathrm{~mm}$.

Occurrence.-Washington: North bank Columbia River, threequarters mile northeast of Knappton; Oligocene series; two specimens of major right manus, one with its propodal finger (holotype), both embedded in nodules. Holotype in California Academy of Sciences. 
Relation.-Obviously akin to $C$. umpquaensis, but differs in having a longer major manus, with margins entire instead of dentate, with a tooth in the gape between fingers, with the tubercles of the outer surface mostly in the distal lower quarter of the palmar portion instead of in the middle of the lower half. The propodal finger has an entire instead of a crenulate upper margin.

CALLIANASSA COWLITZENSIS, new species

\section{Plate 26, figs. 1-3}

Holotype.-Outer surface of manus (pl. 26, fig. 2) evenly convex in a vertical direction, flat midway in a longitudinal direction but curving inward toward the ends. Upper proximal angle with a large blunt tooth projecting backward; from the end of the tooth the upper margin is directed forward and downward in a slightly sinuous line. A row of submarginal punctae. The margin is entire; the four or five tubercles which appear near the middle do not pertain to the outer layer of shell. A stout tooth ( $t$, figs. 1 and 2, pl. 26), tip broken off, projects from the distal end into the interdigital gape just below the insertion of the dactylus. At the base of the tooth on the outer surface there is a small, low, vertically oblong tubercle, and at twice the distance from the end margin another similar, smaller tubercle. These tubercles may not appear, or may be less strong, on the real outer shell. The same may be said of various tubercles on the inner side near the upper distal corner and near the articulation of the dactylus. The inner surface of the manus is flat along the upper and lower margins but convex vertically in the intermediate space (pl. 26, fig. 1).

Additional material.-The carpus (pl. 26, fig. 3) associated with the holotype but belonging to another specimen has an outer surface convex in a vertical direction and nearly flat in the opposite direction. The distal margin is regularly concave except at the ends, the lower margin curves rapidly upward in its proximal half.

Measurements.-Right manus, holotype, length through the middle $26 \mathrm{~mm}$; s superior length $22.5 \mathrm{~mm}$., length measured from the gape just above the immovable finger $22.8 \mathrm{~mm}$., height (approximate) $18.3 \mathrm{~mm}$. Right wrist of another specimen of apparently the same species, distal height $11.8 \mathrm{~mm}$., proximal height (approximate) $8 \mathrm{~mm}$., length through the middle $12.4 \mathrm{~mm}$.

Occurrence.-Washington: On Coal Creek, Cowlitz County, about 21/4 miles up creek from Mount Solo; section 2, township 8 north, range 3 west; Eocene series; one right manus without finger or lower margin, holotype. A right wrist belonging to a smaller specimen may represent the same species. Holotype in University of Washington. 
California: Llajas Canyon, Simi Valley; Santa Susana Shales, the basal member of the Meganos Group, Eocene series; left palm, inside view.

Relation.-This species may be recognized by the strong tooth at the upper proximal end of the manus and the tooth in the gape being adjacent to the dactylus rather than to the fixed finger as in $C$. knapptonensis.

\section{CALLIANASSA CLALLAMENSIS Withers}

Plate 26, figs. 6-12

Callianassa clallamensis Withers, Ann. Mag. Nat. Hist., ser. 9, vol. 14, 1924 , p. 122 , pl. 4, figs. 4-7; type-locality, Clallam Bay, south shore of Strait of Juan de Fuca; Blakeley formation, upper Oligocene; Brit. Mus., Cat. Nos. In. 23789-In. 23797.

Description.-Shape of manus squarish, the upper and lower margins both inclined slightly down at the distal end. Outer surface very convex, especially at the upper third. Upper and lower margins rimmed, entire, with submarginal punctae, of which six are visible along the upper margin and seven along the lower. On the lower distal quarter a group of 14 unequal tubercles besides a row of three above the submarginal punctae (pl. 26, fig. 11). On the upper distal portion a small group of tubercles near the hollow above the articulation of the dactylus and three or four tubercles at a little greater distance. Besides, the whole surface shows evidence of a pavement of oblong tubercles for the most part belonging to a lower layer of shell, but projecting slightly in the lower proximal portion. The inner side (pl. 26, fig. 10) has a similar pavement, which is evident on the surface in two places, near the upper and lower margins both distad to the middle. There are a few (three or four) round tubercles in the upper distal corner behind the much swollen articulation with the dactylus, and one just below the upper margin in the same neighborhood. In the lower distal corner there is a large tubercle at base of finger and a smaller one further back above the margin. Of submarginal punctae there is a row of 22 above the lower margin, the distal six or seven being less crowded; the row along the upper margin shows only about six or seven besides those punctae in the tubercles already mentioned.

The Twin specimens (pl. 26, figs. 6-9) show that the upper proximal corner of the manus is almost right-angled. The specimens are all smaller than the one above described and the tubercles on the lower distal quarter of the outer face run fewer and average smaller. One tubercle or short spine is at the outer edge of the gape close to the dactylus (figs. 7 and 9). On the inner surface there is a row of from four to six tubercles a little below the articulation with the dactylus. There is always present on the same surface the small 
group of tubercles near the upper distal corner, but the corresponding group on the outer surface may be very inconspicuous or represented by only one or two tubercles.

The stump of the fixed finger has on its upper surface two tubercles on its inner margin and one just outside its outer margin. The stump of the dactylus (pl. 26, fig. 8) is smashed flat, but appears to have four large tubercles above and three on the outer side. The distal portion of the carpus (pl. 26, fig. 7) diminishes rapidly in height.

Measurements.-Left manus (N. Pac. 281), length measured horizontally from upper base of fixed finger $21.7 \mathrm{~mm}$., superior length (approximate) $19.6 \mathrm{~mm}$., height at middle $21 \mathrm{~mm}$., height at base of fingers $20.7 \mathrm{~mm}$., height near proximal end $20.7 \mathrm{~mm}$., greatest thickness $10 \mathrm{~mm}$.

Occurrence.-Washington: Shale bluffs along the Nasel River half a mile above mouth of Salmon Creek, Nasel; middle (?) Oligocene series; one left manus.

Washington: Twin, in shale sea cliffs west of West Twin River for a distance of three-fourths mile; upper (?) Oligocene series; 11 specimens of manus, sometimes only a fragment, 6 from the right side and 5 from the left, two with a stump of the fixed finger attached, two others with the base of the dactylus and two with a piece of the carpus.

Relation.-The manus of $C$. clallamensis resembles that of $C$. knapptonensis in having the distal margin vertical in direction and the lower distal quarter of the outer surface tuberculate. It differs, however, in being shorter and in having the proximal margin vertical instead of oblique.

\section{CALLIANASSA TWINENSIS, new species}

Plate 27, figs. 1-4

Holotype.-The manus (pl. 27, fig. 2) increases notably in width from the proximal to the distal end; its lower proximal corner forms a rounded lobe which is produced backward a little beyond the line of the manus-carpus articulation. Upper margin somewhat arcuate, lower margin chiefly straight and inclined downward toward the finger. The distal margin between the fixed finger and the articulation with the dactyl is at right angles to the upper margin but very oblique to the lower margin; it forms a reentering angle with that portion of the distal margin above it, which in turn is oblique to the upper margin. The upper, proximal and lower margins have a thin rim which stands out at an angle with the surface. The outer surface is convex from top to bottom, less so from end to end. Ten tubercles on lower half, all but one in distal quarter; four are larger than the others. The tubercles are different from those found 
in the species above described; they are oblong, vertical, and the hair sockets, with which the tubercles of Callianassa are commonly provided, are not pointing distad close to the surface of the manus, but are directed more, though not completely, normal to the surface. Eight tubercles above the lower margin, the hinder ones very small, the two distalmost long, obliquely placed; an oblong tubercle on base of fixed finger. Near distal end, above articulation of dactylus, a large tubercle, and above it, near the rounded corner, a very small tubercle.

Carpus (pl. 27, fig. 2) detached, smooth, only partially exposed, much less high than manus, and like it convex in both directions but to a lesser degree.

Paratype a.-Fingers and distal portion of right manus, inner view (pl.27, fig. 3). This is part of a smaller cheliped than the holotype but has the appearance of being also a major chela. The fingers are very broad, and when closed they meet while their outer margins are strongly arched. The dactylus has a strong blunt rim separating its two surfaces; the outer surface curves strongly over to the ridge forming really an upper surface, on which there are four large tubercles or sockets, transversely placed at nearly equidistant intervals. The inner surface is marked except distally by a blunt longitudinal ridge, which bears at its posterior end two tubercles and a granule, and divides the surface into two parts oblique to each other; both parts are a little concave, the upper one has a longitudinal row of two sockets in its proximal half, the lower one has a row of three smaller sockets stretching along the middle portion. Distal margin of palm where the dactylus is attached, very oblique; two sockets along this margin and one below the upper margin of the palm not far from the corner. The propodal finger is divided lengthwise by a stronger ridge than that on the dactyl; a row of three sockets below the ridge, and two above the ridge near together.

Paratype b.-Left manus, lower portion lacking. Tuberculation of outer surface similar to that of holotype; supero-proximal angle subrectangular. Inner surface with proximal margin more oblique to upper margin than appears on the outer surface; distal margin oblique as in paratype $a$, with a line of two sockets; instead of one in upper distal corner of palm there is a subvertical row of three; four tubercles on lower distal quarter.

Paratype c.-Right manus embedded in nodule so that only a part of outer surface is visible and no margin except the proximal one.

Paratype d.-Right chela (pl. 27, fig. 4), embedded in a nodule so that the outer surface is visible to a great extent. This specimen resembles those of the type lot in its ornamentation and general appearance except that the upper and lower margins of the manus do 
not diverge distally but converge. This is probably, then, the major chela of a female. The upper margin is more arcuate than in the male, the lower margin is nearly at right angles to the proximal end, and begins to curve upward near base of finger. Tubercles elongate, few, four large ones on the palm forming a $Y$, a small tubercle forming a longitudinal line below the middle. A tubercle on distal margin just above fixed finger. A blunt ridge runs lengthwise through this finger; four tubercles above the ridge, three visible below, tip of finger acute; prehensile edge with a large basal tooth, its margin as well as that of the tooth minutely crenulate, or near the tip very minutely milled. The dactylus has been broken off and slipped down partially behind the other finger; it also has a longitudinal ridge, smooth except for some small tubercles near the articulation; beneath the ridge at some distance one sees three large tubercles.

Occurrence.-Washington: Twin, in shale sea cliffs west of West Twin River for a distance of three-fourths mile; upper Oligocene series; a specimen of right manus and carpus showing the outer surface (holotype) and on the reverse of the nodule the inner surface of a pair of fingers and part of the right manus of a smaller specimen (paratype $a$ ) ; also two other specimens of manus, one left, one right, both incomplete (paratypes $b$ and $c$ ). Holotype in Stanford University. From the same locality, two incomplete specimens of cheliped; University of Washington, Loc. 179.

Washington: About half a mile east of mouth of East Twin River, Clallam County; Oligocene series; one specimen of left cheliped (pl. 27, fig. 1), showing portions of ischium, merus, carpus and proximal half of manus and an impression of the same (paratype $e$, Cat. No. 353334, U.S.N.M.).

Washington: South side of Richs Passage, Puget Sound; basal conglomerate of upper Oligocene, or Blakeley formation; one left chela.

Washington: Sandy shale bluffs on Grays River at Grays River; upper (?) Oligocene series; one right chela, probably of a female (paratype $d$ ).

Measurements.-Holotype, right manus, middle length measured to the gape $12 \mathrm{~mm}$., greatest height, near distal end, $12.6 \mathrm{~mm}$., height near proximal end (approximate) $10.2 \mathrm{~mm}$. Paratype $a$, length of gape between fingers, tips meeting, $8.6 \mathrm{~mm}$., greatest width across fingers when closed $8.7 \mathrm{~mm}$.

Relation.-Differs from all the above described species in the great distal divergence of the upper and lower margins of the manus in the male and in the great width of both fingers and the character of the tubercles. 
Holotype.-Upper margin straight, proximal angle rather prominent, rounded; lower margin slightly arcuate, proximal angle rounded, much less prominent than upper angle; proximal end therefore oblique; distal margin vertical. Outer surface (pl. 27, fig. 6) moderately convex from top to bottom and equally so in upper and lower halves; nearly level in the opposite direction except toward the ends; a deep vertical gutter just within the distal margin. Behind this gutter a curved row of six small tubercles; a similar row of six tubercles at the other end; between the rows are a number of scattered tubercles of more or less prominence, 12 being most elevated. Inner surface (pl. 27, fig. 5) a little flatter than outer, with a distal sutter corresponding to that on the outer surface; behind the gutter a few low, inconspicuous tubercles. Fingers lacking, but a cross section of the propodus at base of fixed finger shows that it occupies about two-fifths the height of distal end of manus.

Paratype a.-The manus (pl. 27, fig. 8) is a little longer relative to its height and perhaps represents a female. The lower margin does not show the arching of the male but is nearly horizontal and slightly sinuous, the finger being inclined somewhat downward, and regularly tapering but incomplete. Lower edge of palm and finger serrate, outer surface of palm covered with distant granules, a row of granules just above middle of finger.

Paratype b.-A larger specimen (pl. 27, fig. 7) than any other, showing a much bruised palm and a finger which had been broken off at its base and turned over toward the outside so that its oblique upper surface looks like part of the outer surface, from which it is separated by a distinct angular edge. The finger lacks a tip but even without it appears unusually long. Enough of the upper margin of the palm remains to show that it is irregularly dentate; the distal outer furrow is less marked than in smaller specimens.

Measurements.-Right manus, holotype, length measured from between fingers $10.5 \mathrm{~mm}$., greatest height $12.3 \mathrm{~mm}$., least or distal height (approximately) $10.5 \mathrm{~mm}$., thickness $4.7 \mathrm{~mm}$. Left propodus including part of finger, paratype $a$, length measured from between fingers $10.7 \mathrm{~mm}$., distal height $10 \mathrm{~mm}$. Paratype $b$, length measured from between fingers $12.6 \mathrm{~mm}$., greatest height $13.2 \mathrm{~mm}$. length of propodal finger on upper margin, minus tip, $15.3 \mathrm{~mm}$.

Occurrence.-Oregon: Shale sea cliffs south of mouth of Five Mile Creek, Bandon; lower (?) Oligocene series; five specimens of manus, three right and two left, free from the matrix. Two others with fixed finger attached, one right and one left, embedded in hard 
nodules. The specimens are all in poor condition and the outer layer absent. Holotype in Stanford University.

Relation.- $C$. bandonensis differs from those above described in the short palm and very long, immovable finger and in the hollow at the distal end of palm.

CALlianassa PORTERENSIS, new species

Plate 28, figs. 1-5

Description.-Manus of major cheliped (pl. 28, figs. 1, 3, 4) with outer surface very convex from upper to lower edge, unevenly convex in a longitudinal direction, being thickest near the proximal end. Lower edge straight, upper edge slightly convex, being depressed distally owing to a dorsal flattening of the outer surface toward the dactylus. Propodal finger curving gradually upward until near the top where it is curved strongly yet still obliquely upward; this finger narrows regularly to near the tip. On the distal end of the manus between the fingers and separated from the fixed finger by a small U-shaped sinus there is a shallow lobe which is itself bilobed,

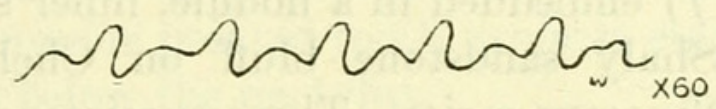

Fig. 5.-Callianassa porterensis. Lower margin of left major propodus, holotype, $\times 60$

the lower lobule bearing three or four marginal denticles, while there may be two or three more denticles near the margin. Upper edge entire, lower edge denticulate except near the proximal end, the obtuse denticles arranged in pairs on shallow subtruncate lobes; the denticulation is continued on the propodal finger.

Surface nearly smooth; on paratypes $a$ and $b$, which have the outer layer of shell preserved, there are very low, oblong tubercles in the lower, middle portion; and the presence of similar tubercles on an inner layer is indicated by oblong light-colored spots of similar shape. On the outer surface of the palm there is a row of punctae close to the lower margin; toward the finger on which the punctae are continued, they become larger, further from the edge and more distant from one another. A submarginal row of a few large punctae along the prehensile margin of the propodal finger (pl. 28, fig. 5). A longitudinal row of two punctae just below middle of palm and near its distal end. A solitary, subdistal puncta above the latter and halfway between it and the upper margin. There are apparently punctae below the upper margin but they are difficult to make out on the outer surface; on the inner surface they are, small and 
numerous. The punctae on the lower and distal part of the inner surface of the propodus are similar to those of the outer surface.

Minor chela ( $\mathrm{pl}$. 28, figs. 2 and 5) narrower than major chela at the distal end of the manus, its lower margin curving gradually upward from the middle of the palm; the finger itself is longer and more horizontal than in the major chela; if it turns upward at all it must be at the extreme end which is not visible in paratypes $b$ and $e$.

Measurements.-Left manus, holotype, length measured from upper base of finger $10.8 \mathrm{~mm}$., greatest height $8.8 \mathrm{~mm}$. Right manus (paratype $c$ ) length measured from upper base of finger $12 \mathrm{~mm}$., length of fixed finger measured from same point $6.3 \mathrm{~mm}$., greatest height of manus $9.3 \mathrm{~mm}$. Right manus (paratype $e$ ), length 13.4 mm., greatest height $10.3 \mathrm{~mm}$.

Occurrence.-Washington: Restoration Point, Bainbridge Island, Kitsap County; upper Oligocene series; one right manus (paratype $e)$ with immovable finger of a female, probably, embedded in a nodule, outer surface exposed.

Washington: Near Porter, section 22, township 17 north, range 5 west; middle Oligocene series; left manus of female with immovable finger (paratype $f$ ) embedded in a nodule, inner surface exposed.

Washington: Shaly sandstone bluff on Chehalis River below Porter; middle Oligocene series. Three specimens of the left manus, two having the propodal finger attached but lacking the tip. The specimen without finger (paratype $a$ ) is separate from the matrix and shows inner and outer surfaces, the others show only the outer surface; the larger of these is considered the holotype; the smaller appears to be a minor chela (paratype $b$ ). Holotype in Stanford University.

Oregon: Sandy shale cut along the Corvallis and Eastern Railway between Rocky Point and Oysterville, Yaquina Bay; Oligocene series. A single nodule containing two specimens of propodus, one (paratype $d$ ) showing the inner surface of a right major propodus complete and the other (paratype $c$ ) the outer surface of a left major propodus incomplete.

Oregon: Shale sea cliffs south of mouth of Five Mile Creek, Bandon; lower (?) Oligocene series; left manus of male with immovable finger (paratype $g$ ), partially embedded in a nodule, inner surface exposed.

Relation.-In the shape and denticulation of the lower margin of the manus, this species is akin to $C$. oregonensis from the Miocene of Oregon, but the latter has a straight propodal finger and the two fingers are nearer together at their origins instead of separated by a broad lobe. 


\section{CALLIANASSA OREgONENSIS Dana}

Plate 28, figs. 6-9

Callianassa oregonensis Dana. U. S. Explor. Exped., Geol., 1849, p. 722 ; atlas, pl. 17, fig. 3 (type-locality, near Astoria, in calcareous concretions of argillaceous rock; Miocene series [probably Oligocene]; type not found, probably not extant).

Description.-No. 5456: Manus (pl. 28, fig. 8) suboblong, outer surface very convex in a vertical direction, lower margin serrate, serrations continued on immobile finger.

Fingers of about equal width, separated at base; gape small, gradnally diminishing toward the tips. Prehensile edges crenulate. Socket-bearing tubercles prominent; a row of five on inner surface of dactylus below upper margin (about a third of finger lacking); two rows of smaller tubercles below, five in the lowest row, three in the intermediate; a row of eight tubercles besides two out of line on the outer surface just over the upper margin. Only three tubercles are visible on propodal finger, at its base, in a row just above but not parallel to lower margin. Outer margins of fingers nearly straight, toward the ends they curve toward each other.

No. 5458: A triangular pointed tooth projects obliquely distad into the gape from just below the dactylus.

No. 5458: A large manus has the upper and lower margins converging distally, and may belong to a female (pl. 28, fig. 7).

No. 5454: Left minor cheliped (pl. 28, fig. 9). Inner margins of fingers sinuous, the dactylus bearing a long shallow lobe at its middle. Two rows of pits on each finger and some additional pits irregularly placed. Carpus wider than manus, distal end oblique, the lower angle produced distad in a triangular tooth. Merus with a high blunt median ridge and a basal wing with similar ridge which reaches to the middle line of the main part of the article.

Measurements.-Minor cheliped, No. 5454: Middle length of manus $12.8 \mathrm{~mm}$., width of manus $7.3 \mathrm{~mm}$., length of fingers $8 \mathrm{~mm}$., length of entire propodus $19.6 \mathrm{~mm}$., middle length of carpus 15 $\mathrm{mm}$., distal height of carpus $8.2 \mathrm{~mm}$., greatest height of same 9.2 mm., length of merus $14.2 \mathrm{~mm}$. Chela, No. 80: Length about 24.5 mm., width $11.7 \mathrm{~mm}$. Cheliped No. 80: Length of ischium $18.8 \mathrm{~mm}$., greatest width or height (across outer and lower surface and large tooth) $10.8 \mathrm{~mm}$., length of carpus $22.2 \mathrm{~mm}$. (perhaps exaggerated), length of manus $17.6 \mathrm{~mm}$., height of same $11.5 \mathrm{~mm}$.

Occurrence.-Washington: Sandy bluffs along Chehalis River for 1 mile east of Helsing Junction, Independence; upper Oligocene; one right wrist. 
Washington: Monterey sandstone bluffs along Wilson Creek 11/2 miles above Willapa; Oligocene (?) series; one specimen of right wrist of large size, about $25 \mathrm{~mm}$. long (pl. 28, fig. 6).

Oregon: West side of Judkins Ridge, Eugene; Oligocene series; one left minor cheliped showing the last four articles (pl. 28, fig. 9) ; Cat. No. 353329, U.S.N.M.

Oregon: Near Eugene; upper Oligocene series. Three specimens: An incomplete right chela, inner surface; distal end of left manus with fingers; left cheliped lacking fingers.

Oregon: One-fourth mile west of Springfield Junction, Southern Pacific Railroad, Lane County; Oligocene series; impression of right manus with inner view of both fingers which show the outer layer of shell but are incomplete (pl. 28, fig. 8) ; Cat. No. 353330, U.S.N.M.

Oregon: Springfield Junction, Lane County; Oligocene series; about 30 nodules containing mostly small fragments but among them several examples of the wrist or the chela (pl. 28, fig. 7); Cat. No. 353331, U.S.N.M.

CALLIANASSA LONGIMANA Stimpson

Plate 29, figs. 3-6

Callianassa longimana Strmpson, Proc. Boston Soc. Nat. Hist., vol. 6, 1857, p. 86.-Schmıтt, Univ. California Publ. Zoöl., vol. 23, 1921, p. 117, text-fig. 79, and synonymy.

Occurrence.-California; Pleistocene :

Rincon del Potrero, Santa Monica; one immovable finger of right major cheliped, and attached to it, the interdigital tooth of palm.

Deadman Island, southeast of San Pedro; one left immovable finger, three right movable fingers (pl. 29, figs. 5 and 6 ).

Spanish Bight, San Diego Bay; upper San Pedro formation; a left, and extremity of a right, movable finger, much worn and a right immovable finger (pl. 29, figs. 3 and 4).

Range of Recent specimens.-From Vancouver Island, British Columbia, to San Quentin Bay, Lower California.

CALLIANASSA STEPHENSI, new species

Plate 18, figs. 5-8

Callianassa, new species, T. S. OLdroyd, Proc. U. S. Nat. Mus., vol. 65, art. 22,1924 , p. 23.

Description.-Immovable finger (pl. 18, figs. 5 and 6): Broad, gradually curved and tapering except for a slight swelling on upper edge proximal to middle. Outer surface slightly convex in a transverse direction, inner surface narrower and flat for a great part of its extent. Two upper surfaces one on either side of the prehensile edge; the outer of these is narrower and almost at right angles to 
the outer surface; the inner one is wider and tapers gradually to a point at tip of finger, its surface is transversely concave and forms a very oblique angle with the inner surface. Lower edge irregularly dentate, teeth short with blunt tips; distal to each tooth on the proximal three-fifths of the margin there is a puncta or hole for the insertion of hairs; on the distal two-fifths of the finger the marginal line of punctae is continued on the outer surface close to the margin by four punctae; a little further from the edge there is " row of five punctae confined to the proximal two-thirds; near the upper edge not far from the top there is a single puncta. The upper edge of the outer surface where it bends abruptly inward is marked by a line of irregularly spaced punctae which are larger on the distal half; this edge has also at its proximal end a line of a few granules. 'The prehensile edge is concave except for a broad, shallow lobe proximal to the middle, as above stated; it is rough with about 36 small but irregular and crowded tubercles. The margin between the inner and the oblique upper surface has about 16 tubercles on its proximal half, rest of margin smooth; among the tubercles are two or more punctae the line of which is continued on the inner surface by two additional punctae placed obliquely. The tip of the finger is short and blunt and curved well upward.

Dactylus or movable finger (pl. 18, figs. 7 and 8): The largest and most eomplete dactylus is among the type lot; it lacks the proximal end, all the material being very fragile. The outer surface is very convex in both directions especially transversely; the inner surface is concave in a longitudinal direction, and is bluntly ridged through the middle lengthwise. Upper and lower edges convex, converging to a point where the tip of the finger turns abruptly and vertically downward. Prehensile edge bearing 21 larger and proximally seven or more smaller tubercles. Upper edge having small blunt teeth gathered mostly in distant groups of two or three. On the outer surface just below this margin are four large holes, and a little farther above the lower margin three large holes unequally spaced. On the inner surface the holes are smaller and five in number; two form a line across the middle, while a third makes an $\mathbf{L}$ with these and is situated near distal end not far from prehensile edge; the other two are submarginal near proximal lower end and are socketed so as to direct the hairs upward.

Measurements.-Holotype, left immovable or propodal finger, length on upper edge $12 \mathrm{~mm}$., greatest width (at origin) $5 \mathrm{~mm}$.

Occurrence.-California; Pleistocene series:

Nob Hill (lumber yard), northeast of San Pedro; Lower San Pedro formation; 1 left movable finger, 14 immovable fingers, 3 right, 11 left; Cat. No. 353332, U.S.N.M. 
Signal Hill (or Los Cerritos), northeast of Long Beach; upper San Pedro formation; one right movable and one right immovable finger.

Spanish Bight, San Diego Bay; upper San Pedro formation, Pleistocene series; two movable fingers, one right, one left, three immovable fingers, one right, two left; one of the latter is taken as holotype. Cat. No. 353333, U.S.N.M. Twelve other smaller immovable fingers, four right, eight left, were collected at the same place by Mrs. Stephens.

Relation.-This species is related to the Recent $C$. californiensis Dana, but the Pleistocene species has wider fingers, the propodal finger has flatter inner and outer surfaces. The ornamentation of teeth, tubercles and hair-sockets is similar in the two species.

\section{Genus UPOGEBIA Leach}

Upogebia Leach, Edin. Encyc., vol. 7, 1814, p. 400; type, U. stellata (Montagu).

First pair of legs subequal and subchelate; remaining pairs simple. Eyestalks cylindrical; cornea terminal. Rostrum short, stout, tridentate.

Eocene; Recent. The fossil forms hitherto referred to Upogebia have since been placed in other genera. ${ }^{52}$

\section{UPOGEBIA (UPOGEBIA) EOCENICA, new species}

Plate 29, figs. 1 and 2 ; plate 30

Description.-Five specimens show the carapace. Lateral margin spinous. Front quinquedentate (pl. 29, fig. 1), the rather broad median tooth flanked by a very small, acute tooth and separated by a shallow sinus from a somewhat larger tooth which is a little less advanced. These two small teeth, the intermediate and the outer tooth, are situated on either side of a broad smooth gutter which runs along within the lateral margin of the rostrum and is continued on the gastric region. The scabrous surface of the rostrum is continued backward nearly to the cervical suture; the tubercles or sockets are conical, pointed above and widen out anteriorly forming a surface covered with minute punctules which formerly served as sockets for hairs. The tubercles form a single row on the lateral marginal ridge and several very irregular rows on the remaining area, on the rostrum two rows, and further back about three rows, each side of the median line. One specimen (holotype) shows the

52 Van Straelen, Mém. Acad. Roy. Belgique, Cl. Sci., ser. 2, vol. 7, 1925, p. 309. 
orbital spine on the right side characteristic of the typical subgenus (pl. 29 , fig. $1 s$ ); the tip is broken off but the spine is stronger than in Recent species; the eyestalk is visible below, but it is detached and reversed.

The third and fourth segments of the abdomen (paratype $f$ ) have a groove setting off the anterior part of the lateral margin (pl. 30 . fig. 2); the adjacent surface bears a patch of very fine punctules indicating hairs; the anterior angle is produced in a shallow lobe which is rounded in the third segment, subacute in the fourth; the sixth segment has sinuous lateral margins (pl. 30, fig. 1,6), and is widest across its middle. Telson (paratype $f$ ) coarsely punctate, a deeply impressed median line. The inner appendage forming the tail fan (tf, pl. 30, figs. 1 and 2$)$ bears three smooth costae and the outer appendage two.

The chelipeds are equal (paratype $a$ ). The arm (paratype $g$ ) is massive, surface wrinkled, distal end flattened dorsally in a triangular surface. The wrist (paratype $c$ ) has a crenulated inner edge, a stoutish inner distal spine, a few smaller distal spines; the dorsal surface has two longitudinal grooves meeting at the middle of the distal end. Palm (paratype $h$ ) much swollen (pl. 30, fig. 3), diminishing at the proximal end; upper part of outer surface granulate; inner surface with a longitudinal groove above, and below that on the proximal three-fifths a series of eight oblique well-separated stridulating ridges (paratypes $e$ and $h$ ), an unusual arrangement in the genus (pl. 29, fig. 2 ; pl. 30, fig. 18 ) ; just proximal to those are sereral tubercles; above the lower margin there is a smooth longitudinal ridge in the upper slope of which are numerous punctules. The immovable finger (paratype $c$ ) is short, slender, curved, deflexed (pl. 30, fig. 4) and much smaller than the dactylus. The latter (paratype $b$ ) is only partially exposed; it has a few large tubercles on the upper edge, a groove through the middle, the lower edge of which is granulate.

Of the remaining pereiopods, the upper half of the outer surface of at least two (paratype $e$ ) is granulate, granules more or less arranged in short transverse rows, upper surface punctate.

Measurements.-Paratype $a$, length of carapace in front of the cervical suture $8 \mathrm{~mm}$., length of palm $7 \mathrm{~mm}$. Paratype $h$, length of palm $10.7 \mathrm{~mm}$.

Occurrence.-Washington: Railroad bluff about $1 \frac{1}{2}$ miles south of Vader, Lewis County, about 700 feet below railroad post No. 79, section 4 , township 11 north, range 2 west; Eocene series; portions of at least six individuals, one of which is holotype; in University of Washington. 


\section{Superfamily HIPPIDEA de Haan}

\section{Family ALBUNEIDAE Ortmann (ALBUNIDAE Stimpson)}

First pair of legs subchelate; second to fourth legs with last joint curved and flattened. Carapace flattened, without wings to cover the legs. Third maxillipeds narrow, with exopodites. Abdomen bent under thorax; tail-fan not adapted for swimming.

\section{Genus BLEPHARIPODA Randall}

Blepharipoda Randall, Journ. Acad. Nat. Sci. Philadelphia, vol. 8, 1839 (1840), p. 130 ; type, B. occidentatis Randall.

Eye peduncles very slender, elongated, cylindrical, and articulated in the middle. Antennae with an acicle. Third maxillipeds with third or merus joint narrow and similar to the fourth, or carpus, which is not produced at its antero-external angle.

Oligocene; Recent.

\section{BLEPHARIPODA BRUCEI, 53 new species}

Plate 28, figs. 10 and 11

Description.-Similar color and ornamentation of the four fragments indicate a single species. The palm has a margin peculiar to Blepharipoda occidentalis ${ }^{54}$ a hitherto unique species of its genus which inhabits the waters of the west coast of America from San Francisco to Lower California.

The palm (holotype) shows the outer surface, lacking the upper portion and the proximal end, and a narrow strip of the inner surface above the lower margin (pl. 28, fig. 11). The horizontal distance from the interdigital sinus to the fracture is $6.7 \mathrm{~mm}$. The palm is thick, proximal cross-section oval. Surface granulate, granules mostly combined by twos or threes or even fours. Lower margin subacute, interrupted a little distad of the middle by a stout spine of which only the base remains. The hand appears to reach its greatest height at the spine; behind the spine the margin is slightly convex, in front of it concave; the margin is accented by a line of fine granulation, the granules mostly alternating in two crowded rows. Immediately above there is a narrow, smooth strip. On the inner surface there is an irregular row of seven granules close to the margin, on the remaining surface visible the granules are less crowded than on the outer surface.

The merus or arm is $8 \mathrm{~mm}$. long, $4.2 \mathrm{~mm}$. wide at the middle, distal lower corner not visible (pl. 28, fig. 10). Near the distal upper corner

\footnotetext{
${ }^{53}$ For Prof. Bruce L. Clark of the University of California through whom much of the material used in this paper was loaned to the author.

a Randall, Journ. Acad. Nat. Sci. Philadelphia, vol. 8, 1839, p. 131, pl. 6.
} 
is the attachment of seemingly two large spines. The surface is not entirely granulate; through the middle there is a broad longitudinal smooth band, and a little above this and separated from it by a rough line of granules, there is another but narrower smooth strip; the extreme upper part of the outer surface is smooth; the granules of the lower half are mostly fine. An indication of a spine on lower margin a little distad to the middle.

The carpus or wrist is very incomplete as to the distal end, the extreme length visible is $5.2 \mathrm{~mm}$., the width $4 \mathrm{~mm}$. Surface very convex transversely, upper half granulate, also distal end of lower half; lower proximal portion smooth, with a dimple near the articulation with the merus; the upper distal half is much more produced than the lower half, as in B. occidentalis.

The fourth fragment appears to be the upper part of a manus, with the condyle at the articulation with the dactylus; surface very uneven and finely granulate.

Occurrence.-Washington: Sea cliffs between Classens Wharf and ship canal estuary, Townsend Bay; lower Oligocene series; two specimens, one containing a right manus, holotype, and what appears to be the left merus of the cheliped, outer-upper face, and the other containing a left carpus and a fragment which may be part of a manus. Holotype in Stanford University.

Relation.-This can not be referred to the Recent $B$. occidentalis because in the latter the lower edge of the palm is thinner and sharper and the granules of the outer surface form longer lines which are arranged more or less in parallel rows.

\section{Tribe ASTACURA Borradaile}

\section{Family ERYMAIDAE Van Straelen, $1925^{55}$}

Carapace subcylindrical, rostrate, having always a well-developed cervical suture and postcervical and branchio-cardiac sutures. Antennules biflagellate. Antennae with a long flagellum and a scaphocerite. Dieresis of external uropod. (Van Straelen.)

\section{Genus ERYMA von Meyer}

Eryma von MEYER, in Leonhard and Bronn's Jahrbuch für Mineralogie, 1840, p. 587 ; Neue Gattungen Fossiler Krebse, Stuttgart, 1840, p. 18.

Rostrum medium; cervical suture deep; branchio-cardiac and postcervical sutures nearly parallel; hepatic sutures almost encircling a tubercle formed between these sutures, the cervical and the antennal sutures; on median line in front of cervical suture a fusiform area limited by two furrows; the antennular flagella inserted on a short 
peduncle; scaphocerite sharp; third pair of maxillipeds well developed; first three pairs of pereiopods provided with a chela, last two pairs with a terminal dactyl; uropods wide and bladelike. (Van Straelen.)

Jurassic; Cretaceous.

\section{ERYMA DAWSONI Woodward}

Plate 35, fig. 1

Eryma dawsoni Woopward, Geol. Mag., n. s., dec. 4, vol. 7, 1900, p. 400, pl. 16, fig. 2.-Whiteaves, Mesozoic fossils, vol. 1, pt. 5; Geol. Surv. Canada, Ottawa, 1903, p. 321, pl. 41, fig. 2.

Type-locality.-British Columbia: Hornby Island. Cretaceous.

\section{Genus ENOPLOCLYTIA M'Coy}

Enoploclytia M'Coy, Ann. Mag. Nat. Hist., ser. 2, vol. 4, 1849, p. 330 ; type, E. leachii (Mantell).

Carapace strongly rostrate; branchial regions dilated; cervical suture very deep and wide; gastro-orbital furrow constant; postcervical sutures more important than the cervical suture but diminishing greatly downward; branchio-cardiac sutures extremely reduced; first three pairs of pereiopods terminate in massive chelae, especially the first, the two last pairs with terminal dactyls; carapace and pereiopods covered with large tubercles.

Jurassic; Cretaceous.

ENOPLOCLYTIA MINOR Woodward

Enoploclytia minor Woodward, Geol. Mag., n. s., dec. 4, vol. 7, 1900, p. 434.Whiteaves, Mesozoic fossils, vol. 1, pt. 5 ; Geol. Sur. Canada, Ottawa, 1903 , p. 321.

Type-locality.-British Columbia: Hornby Island. Cretaceous.

\section{Family ASTACIDAE Hagen}

Carapace subcylindrical, free from epistome, and divided by a transverse cervical groove. Rostrum of moderate size.

First three pairs of legs chelate, first pair much larger than the others; last two pairs not chelate. Posterior thoracic somite united to the preceding by a movable joint. Exopodite of uropods divided by a suture.

\section{Genus MEYERIA M'Coy}

Meyeria M'Coy, Ann. Mag. Nat. Hist., ser. 2, vol. 4, 1849, p. 333 ; type, M. ornata (Phillips).

Carapace strongly compressed, high; cervical suture very deep, $\mathrm{V}$-shaped, lateral portions nearly straight, meeting above in an acute angle considerably in front of middle and extending to lateral 
margins at a point deeply notched by the abrupt narrowing of the front thence to the sharp rostrum; hepatic sulcus acutely angular; branchial furrow forming a nearly straight, delicate impressed line from near the lower ends of the cervical suture to middle of each side of posterior margin, never meeting on midline of back. Abdomen semicylindrical, large, ends of second segment dilated, rotund, of the others subtrigonal; outer branch of tail fan with a transverse suture. Legs slender.

Cretaceous.

\section{MEYERIA (?) HARVEYI Woodward}

Meyeria (?) harveyi Woodwand, Geol. Mag., n. s., dec. 4, vol. 7, 1900, p. 434.

Type-locality.-British Columbia: Hornby Island. Upper Cretaceous.

\section{Genus HOPLOPARIA M'Coy}

Hoploparia M'Coy, Ann. Mag. Nat. Hist., ser. 2, vol. 4, 1849, p. 175; type, H. longimana (Sowerby).

Carapace subcompressed, sides broad; cervical suture deep, disappearing on the sides; hepatic sulcus bifurcate, $\lambda$-form; rostrum awl-shaped; supra-antennal process semi-cylindrical, covering the base of the scale of the outer antenna. First pair of feet, or chelipeds, large, unequal; the major stout, digits strongly tuberculate; the minor more slender, digits armed with numerous subequal denticles; remaining feet slender. Abdomen subcylindrical, epimera falcate, acuminate.

Cretaceous; Eocene.

\section{HOPLOPARIA BENNETTI Woodward}

Hoploparia bennetti WoodwaRD, Geol. Mag., n. S., dec. 4, vol. 7, 1900, p. 433.

Hoploparia bennettii Whiteaves, Mesozoic fossils, vol. 1, pt. 5, Geol. Sur. Canada, Ottawa, 1903 , p. 320.

Type-locality.-British Columbia: Comox River. Upper Cretaceous.

\section{HOPLOPARIA (?), species (Gabb)}

"Gen ? Sp. indet." "Three fragments of claws, remarkable for their long, slender form" GABB, Geol. Sur. California, Palaeont., vol. 2, 1869, pp. 127 and 209, pl. 19, figs. $2 a-f$.

Occurrence.-California: Cottonwood Creek, Shasta County. Lower Cretaceous: Shasta group. 


\section{Genus ASTACUS Fabricius, Milne Edwards}

Astacus FABRICIUS, Syst. Entom., 1775, p. 413 (part).

Astacus Milne Edwards, Hist. Nat. Crust., vol. 2, 1837, p. 329; type, $A$. astacus (Linnaeus).

Body robust and ovate; first pair of abdominal appendages of male neither bifid nor toothed at tip; no hooks near base of any of thoracic legs.

The last thoracic somite bears a pleurobranchia on each side, the full number of gills being 36 ; there are besides two or three rudimentary gills on each side of body; the hindmost podobranchia is provided with a plaited, bilobed lamina, like those in front. The orifice of the green gland is situated on posterior face of tubercle. The annulus ventralis is represented by a transverse ridge behind the penultimate thoracic sternum.

Miocene; Pliocene; Recent.

\section{Astacus CHENODERMa Cope}

Plate 29, fig. 7 ; plates $31-34$

Astacus chenoderma Cope, Proc. Amer. Philos. Soc., vol. 11, (1870) 1871, p. 606 ; type-locality, Catharine's Creek, Idaho; topotypes in U. S. Nat. Mus., Cat. No. 353343 (Smithsonian No. 9779); cotypes perhaps not extant.

Astacus breviforceps Cope, Proc. Amer. Philos. Soc., vol. 11, (1870) 1871, p. 606 ; type-locality, Catharine's Creek, Idaho.

Carapace (pl. 31, fig. 1; pl. 33, fig. 3) : Surface finely wrinkled; numerous granules or small tubercles with anterior openings for insertion of hair. In cases where the surface has been worn and the granules obliterated or partly so, the punctae appear larger on an otherwise smooth surface. Cervical suture very deep. Grooves on either side of the cardiac region far apart. A blunt median carina on the anterior portion of the carapace is continued for a short distance on the basal portion of the rostrum, diminishing in width anteriorly. Rostrum (pl. 33, figs. 1 and 3 ; pl. 34, figs. 1 and 2) long, diminishing gradually to a point, bordered on each side by a strong carina, which is roughened by unequal and unevenly spaced tubercles up to the number of seven; the carina is continued behind the line of the orbit. Outside this portion of the carina and wholly behind the orbit there is an obliquely longitudinal line formed by two teeth or tubercles the posterior slope of which is elongate.

Abdomen (pl. 29, fig. 7; pl. 32; pl. 33, fig. 5) : Surface similar to that of the carapace but with the tubercles and their punctae more numerous. When the surface is a little worn the punctae are much more conspicuous. First somite short, produced laterally in a slender pleuron. Second somite twice as long as the first, its pleuron sub- 
orbicular, anterior and posterior margins broadly arcuate, posteroexternal portion outwardly produced; this pleuron is about one and a half times as long (in the direction of the axis of the crayfish) as the greatest length (in the same direction) of any of the next three pleura. The third, fourth and fifth somites are of subequal length, their pleura similar, falcate, each extending laterally a distance equal to that between articulations. The sixth somite is about the same length as those preceding, but its pleuron is subtriangular, about half as extensive and directed obliquely backward. The telson (pl. 32, fig. 2) is about seven-eighths as wide at its origin as its length; its lateral margins converge slightly in the proximal half, strongly in the distal half, the extremity broadly arcuate; the lateral incision is at the distal two-fifths of the length. The branches of the tail-fan are broadly oblong-oval; when longitudinally disposed the inner branch exceeds the telson very slightly while the outer one is considerably longer; the transverse suture of the outer branch is almost in line with (a little in advance of) the posterior end of the telson, and is marked by a row of spines and spinules.

Chelipeds: Unequal, asymmetrical, one chela (either right or left) longer and slenderer than the other. The first is the chenoderma type, the second the breviforceps type. Surface rougher than that of the body. Merus (pl. 33, fig. 2) twice as long as its greatest width, margins tuberculate; upper margin with a single row of tubercles ending in a cluster of tubercles just behind the transverse distal furrow; a row of tubercles on either margin of the narrow lower surface, and on the distal margin, ending in a cluster of tubercles at the outer angle. Carpus (pl. 31, fig. 5) with a deep tongitudinal furrow in its upper surface, the portion outside the furrow very coarsely and roughly tuberculate. Palm of major chela (pl. 31, fig. 5) as wide as its length between articulations with carpus and dactylus; palm of minor chela (pl. 31, fig. 2) somewhat narrower than its length between articulations. Their outer or upper surface is rougher than the inner or lower one and the tubercles are larger and more abundant toward the margins where the sockets with which they are provided probably supported a coating of soft hair. The fingers are long and flattened, longer in the minor chela (pl. 31, fig. 3). In the minor chela the outer edge of the dactylus or movable finger is concave, and the opposite or prehensile edge is slightly convex; the outer edge of the immovable finger is convex and the prehensile edge concave; the fingers therefore meet when closed. In the major chela the prehensile edges of both fingers are somewhat concave and the outer edges convex, resulting in a narrow interspace at least in the proximal half when the fingers are closed (pl. 31, fig. 5). 
Ambulatory legs (pl. 34, figs. 2 and 3): Of the ambulatory legs the carpus and the ischium are of about equal length and the merus about twice as long as either.

Measurements.-Eldorado specimens: Width of largest carapace, measured on its circumference, $67 \mathrm{~mm}$.; width of largest palm 31 $\mathrm{mm}$. Approximate length of large specimen from tip of rostrum to tip of telson $172 \mathrm{~mm}$.; length of abdomen $86 \mathrm{~mm}$.

Occurrence.-Oregon: Near Eldorado, Malheur County; Pliocene series; ${ }^{56}$ upwards of 1,000 fragmentary specimens representing at least 200 individuals in Yale Museum.

Oregon: Section 34, township 19 south, range 43 east, Snake River Valley, Malheur County; Payette formation, Miocene series; three specimens representing at least two individuals; Cat. No. 353341, U.S.N.M.

Oregon: Near Vale, Malheur County; Payette formation, Miocene series; nine specimens; Cat. No. 353342, U.S.N.M.

Idaho: Catharine's Creek (local name for upper part of Castle Creek), Owyhee County; Pliocene series (?) ; ${ }^{57}$ J. C. Schenk, collector, for Clarence King, in charge United States Geological Exploration of fortieth parallel; two abdomens, five carapaces, one major and one minor manus; Cat. No. 353343, U.S.N.M. ${ }^{58}$

sв Dr. John P. Buwalda writes, after a study of mammalian remains in Oregon : “I think it probable that if the rock in which the crayfish were entombed is fairly well indurated, the age can, with quite a high degree of probability, be assigned to upper Miocene and lower Pliocene."

${ }^{57}$ Cope says of his species there is "great probability of their being later than Miocene, and nothing to conflict with their determination as of Pliocene age." (Cope, Proc. Amer. Philos. Soc., vol. 11, (1870) 1871, p. 547 ; Faxon, Mem. Mus. Comp. Zoöl., vol. 10, 1885, p. 156.)

For discussion of the present state of knowledge in regard to the horizons of the Castle Creek deposits, see Dall, Discovery of a Balkan fresh-water fauna in the Idaho formation of Snake River Valley, Idaho. Professional Paper 132-G, U. S. Geological Survey, 1924.

${ }^{5}$ Although the two species above were said to be in the Smithsonian collection, they were not sent there by Professor Cope. In 1881, Prof. A. S. Packard wrote (Bull. U. S. Geol. Surv., vol. 6, no. 2, pp. 393 and 394): "We may in this connection [description of Cambarus primaevus] refer to the three fossil forms from Idaho Territory, described by Prof. E. D. Cope, who has kindly allowed us to examine his type specimens (those of A. subgrundialis excepted), which were collected by $\mathrm{Mr}$. Clarence King, in charge of the survey of the fortieth parallel." In June, 1898, Prof. Packard wrote to Prof. George P. Merrill: "I send tomorrow a small box containing the fossil Astacus from Idaho, which was loaned by the late Professor Cope and which was not returned to him. It should be added to the National Museum."

These specimens, 13 in number, are now in the National Museum. They were collected by J. C. Schenk for Clarence King in Deposit 1, Catharine Creek, Pliocene series (?). There are no specific labels attached to them, nor are they separated or separable into two species. They do not appear to be the type specimens described, but they may be specimens from which the types were selected. If they really represent $A$. chenoderma and $A$. breviforceps, then those species are synonymous.

It is highly probable that Cope's A. subgrundialis (loc. oit., p. 605) also is conspecific with chenoderma for its chief character is the spination of the upper margin of the chelae. Although I find no spines remaining on this margin, it is likely that many of the coarse, broken tubercles present possessed in the beginning spiniform horny tips. 
Relation.-This species appears to be the ancestor of $A$. gambelii (Girard) ${ }^{59}$ through A. gambelii connectens Faxon ${ }^{60}$ both of which forms now inhabit the Snake River valley in Idaho. A. gambelii and its subspecies have a rostrum bordered by stout spines as in $A$. chenoderma; and A. g. connectens has the prominent posterior spine on the postorbital ridge, which is present in chenoderma but not in typical gambelii. The bearded manus of gambelii apparently existed in chenoderma. The asymmetry of the chelae of chenoderma, an asymmetry the constancy of which it is impossible to determine owing to the fragmentary character of the material, is repeated, to a limited extent in old males of typical gambelii, where, however, the right chela is the larger of the two.

\section{Tribe PALINURA Borradaile \\ Superfamily GLYPHEIDEA Van Straelen, 1925}

Carapace subcylindrical, rostrum well developed; eervical suture deep; branchio-cardiac sutures present; cephalic region carinated; at least the first pair of pereiopods with a terminal dactyl or leptochelate; exopod of uropods with a dieresis. (Van Straelen.)

\section{Family GLYPHEIDAE Winckler}

Scaphocerite present.

\section{Genus GLYPHEA von Meyer}

Glyphea von MEYer, Neue Gattungen fossiler Krebse, Stuttgart, 1840, p. 10 ; type, G. regleyana (Desmarest).

Rostrum moderately elongate; cervical suture very deep; branchiocardiac and postcervical sutures subparallel in a large part of their course; carinae nearly always present on cephalic region; antennules biflagellate, peduncles very long, consisting of at least three articles, flagella short and subequal; antennae with a flagellum longer than those of the antennules, and a very long peduncle with a pointed scaphocerite; third pair of maxillipeds well developed; all five pairs of pereiopods with terminal dactyls, the first pair extremely long, subcheliform; telson wide and rounded; uropods in form of palettes. (Van Straelen.)

Triassic to Cretaceous.

\footnotetext{
${ }^{59}$ Hagen, Ill. Cat. Mus. Comp. Zoöl., No. 3, 1870, p. 90, pl. 1, figs. 97, 98 ; pl. 3, fig. $170 ;$ pl. 11.

${ }^{\omega}$ Mem. Mus. Comp. Zoöl., vol. 40, 1914, p. 360 , pl. 7 , figs. 6 and 10 ; pl. 10, fig. 1.
} 
GLYPHEA, species, Whiteaves

Glyphaea sp. nov., Whiteaves, Mesozoic fossils, vol. 1, pt. 5; Geol. Sur. Canada, Ottawa, 1903, p. 323.

Occurrence.-British Columbia; Nanaimo, Vancouver Island. Cretaceous.

\section{Superfamily SCYLLARIDEA Stebbing}

\section{Family PALINURIDAE Gray}

Carapace subcylindrical, fused at sides to epistome. Rostrum small or wanting. Eyes not enclosed in separate orbits formed by edge of carapace. First joint of second antenna fused with epistome; flagellum long, cylindrical, rigid, multiarticulate. None of the legs much longer than the rest, or, except sometimes the first pair, chelate. Tail-fan divided by indistinct sutures into a soft hinder half and a harder front half. Telson roughly square behind.

\section{Genus PODOCRATUS (Becks MS.) Geinitz}

Podocratus BEcks MS., in Geinitz, Das Quadersandsteingebirge oder Kreidegebirge in Deutschland, Freiberg, 1849, p. 96 ; type, $P$. dülmense Becks.

Podocrates Schlüter, Zeitschr. deut. geol. Gesell., vol. 14, 1862, p. 710.

Linuparus (part) Ortmann, Amer. Journ. Sci., ser. 4, 1897, p. 296.

Antennal flagella short. No spines on antennular ring. Two frontal horns. A median dorsal and two lateral carinae on carapace and abdomen. Cretaceous.

\section{PODOCRATUS CANADENSIS (Whiteaves)}

Plate 35 , fig. 2 ; plate 36

Hoploparia (?) canadensis Whiteaves, Trans. Roy. Soc. Canada, vol. 2, 1884 (1885), sec. 4, pp. 237-238; Contrib. to Canadian Palaeontology (Geol. Survey of Canada), vol. 1, pt. 1, 1885, p. 87, pl. 11.

Podocrates canadensis Whiteaves, Proc. and Trans. Roy. Soc. Canada, ser. 2, vol. 1, 1895, p. 133.

Linuparus (Podocrates) canadensis Woodward, Geol. Mag., n. s., dec. 4, vol. 7,1900 , p. 396 , pl. 16 , fig. 1 .

Linuparus canadensis Whiteaves, Mesozoic fossils, vol. 1, pt. 5; Geol. Sur. Canada, Ottawa, 1903, p. 325.

Description.-In both this species and the next, the median keel is absent in front of the cervical suture (pl. 36; pl. 37, figs. 1 and 2); in $P$. canadensis it is stronger than the obtuse lateral keels and is three times as broad posteriorly as anteriorly. The keels each have a series of larger conical tubercles whose acute apices point forward.

Just in front of the cervical groove are five tubercles in two converging rows of two pairs and an odd one, which if connected by lines would have much the shape of an isosceles triangle with its 
base near the furrow. In front of these five tubercles are four others, still larger, forming a quadrangle whose sides are greater than the base of the isosceles triangle indicated by the other five.

Carapace between grooves covered with small, isolated, rather distant conical tubercles, occasionally surrounded by a minute annulus at base.

Occurrence.-Northwest Territory: Highwood River, a tributary of Bow River, Alberta; Cretaceous (type-locality). British Columbia: Vancouver Island, Cretaceous (Whiteaves); Hornby Island, Upper Cretaceous (Woodward).

\title{
PODOCRATUS VANCOUVERENSIS (Whiteaves)
}

\section{Plate 37}

Podocrates vancouverensis Whiteaves, Trans. Roy. Soc. Canada, ser. 2, vol. 1,1895 , sec. 4 , p. 132.

Limuparus (Podocrates) vancouverensis Woodward, Geol. Mag., n. s., dec. 4, vol. 7, 1900, pp. 393-395, pl. 15, figs. 1-3.

Linuparus vancouverensis Whiteaves, Mesozoic fossils, vol. 1, pt. 5; Geol. Sur. Canada, Ottawa, 1903, p. 323, pl. 40, figs. 1-3.

Type-localities.-British Columbia: 2 miles up Puntledge River, Vancouver Island (Mus. Geol. Surv. Canada, Ottawa), also Hornby Island; Cretaceous, Nanaimo group.

Description.-On the posterior portion of the carapace (pl. 37, figs. 1 and 2) the three longitudinal ridges are minutely tuberculate and extend from posterior margin to cervical groove where each terminates in a pointed tubercle larger than any of the rest.

Just in front of the groove there is an ovate-lanceolate area, elevated at pointed end anteriorly and margined with a single row of small tubercles. Immediately in front of this area, a pointed or spinous tubercle, almost in line with the largest tubercle on each of the lateral ridges; still further forward are two similar tubercles at a short distance from the outer margin.

Carapace between grooves minutely granulate and setose.

\section{Order STOMATOPODA Latreille}

\section{Family CHLORIDELLIDAE Rathbun (SQUILLIDAE Miers)}

\author{
MANTIS SHRIMPS
}

Exopodite of uropod composed of two quite distinct segments.

\section{Genus CHLORIDELLA Miers (SQUILLA Fabricius)}

Chloridella Miens, Ann. Mag. Nat. Hist., ser. 5, vol. 5, 1880, p. 13 ; type, $C$. microphthalma (Milne Edwards).

Carapace with well-marked carinae. Cervical groove defined across dorsum of carapace. Cornea of eyes bilobed. First five 
abdominal somites with longitudinal carinae. Raptorial dactylus not inflated at base, armed with teeth on inner margin. Telson with median carina, and smooth, pitted, tuberculate or carinate on either side; distal margin with three pairs of large teeth; one or more submedian denticles, several (more than four) intermediate and one lateral.

Jurassic; Cretaceous; Eocene; Miocene; Pliocene(?); Recent.

\section{CHLORIDELLA SONOMANA, new species}

Plate 38, figs. 1 and 2

Description.-This fragment is bent at its middle between the second and third abdominal segments and the two halves pressed close together. The fragment of carapace $(c$, fig. 2$)$ shows 5 carinae, the median carina is posteriorly bifurcated, the forks united a little in front of the margin and then ending in an elongate tubercle. The outer carina extends nearly to the posterior margin. The intermediate carina is interrupted by the transverse suture; behind that point it curves outward and then forward to unite with the outer margin. The short fifth thoracic segment (5, fig. 2 ) has no submedian carina, and no lateral carina is in evidence. A lateral carina is present on the sixth, seventh and eighth thoracic segments $(6, \%, 8$, fig. 2$)$. The carinae of the six abdominal segments are as follows: The submedian carina is continuous, except on the first segment which has lost its middle portion (1, fig. 2 ) ; the lateral carina is found on all, also the submarginal carina except on the second segment (2, fig. 2) where its presence is indeterminable; marginal carina on first (fig. 2), third and fourth (fig. 1) segments, second (fig. 2) and fifth (fig. 1) indeterminable. None of the carinae now have terminal spinules but the extremities show a place for their insertion; the only exception among complete carinae is the submedian third abdominal which diminishes gradually in height at its terminus. The lateral carina of the sixth segment (fig. 1) is curved, concave outward, the anterior half of the curve nearly transverse and situated near the anterior margin; this half is followed by a shallow furrow across the ridge, behind which there is a short, blunt, elevated, backward-pointing tooth. Two median granules are present on second to fifth segments inclusive, the sixth is broken in the middle.

Measurements.-Holotype, length from anterior margin of fifth thoracic segment to hind margin of sixth abdominal segment, about $72.3 \mathrm{~mm}$.; width across fifth abdominal segment lacking lateral margins $32.7 \mathrm{~mm}$.

Occurrence.-California: $5 \frac{1}{2}$ miles southeast of Santa Rosa, three-tenths mile upstream from bridge crossing Matanzas Creek 
on left bank, four-tenths mile north of Grangers Hall, Sonoma County; Pliocene (?) series; one specimen, holotype, extending from the hind part of the thorax to the sixth abdominal segment, inclusive. Holotype in University of California.

Relations.-As the holotype lacks those parts commonly used in diagnosing species, namely, the anterior and posterior ends of the body and all of the appendages, it is impossible to assign the fossil species to its proper place within the genus. It appears to be related to certain of those species which now inhabit the deeper waters off the Pacific coast of North America: C. panamensis (Bigelow) ${ }^{61}$ and $C$. biformis (Bigelow). ${ }^{62}$ The carapace is similarly carinated, especially that of panamensis, where the space between the branches of the median carina behind the transverse suture is the same form and the space outside the intermediate carina is equally oblique, but in sonomana the space is considerably wider in proportion to the full width of the carapace, and the posterior curve of the carina is a wider arch. The lateral carina of the sixth abdominal segment is similar in direction in the three species, and is interrupted in the middle, but neither of the Recent species has the same blunt tooth behind the break as is seen in sonomana.

\section{Genus PSEUdosqUilla Guérin MS., Dana}

Pseudosquilla Gú́rin, in Dana, U. S. Expl. Exped., vol. 13, Crustacea, pt. 1, 1852, pp. 615 and 621 ; type, P. lessonii (Guérin).

Carapace without carinae. Cervical groove not extending across dorsum of carapace. Cornea of eyes rarely bilobed. First five abdominal somites without longitudinal carinae. Abdomen usually compressed. Raptorial dactylus not inflated at base and with two, rarely three, teeth (excluding terminal tooth) on inner margin, or unarme 1 . Telson with sharp median carina and in adults with other carinae on either side, the submedian with movable tips; no marginal submedian denticles, never more than three intermediate denticles.

Niocene; Recent.

PSEUDOSQUILLA ADELAIDENSIS, new species

Plate 38 , fig. 3

Description.--The species has the strongly arched abdomen with the first five segments smooth which characterizes all the members of the genus. The sixth segment shows four carinae, submedian,

${ }^{61}$ Proc. U. S. Mus., vol. 17, 1894, p. 526, text-figs. 17 and 18.

${ }^{62}$ Idem, p. 532, pl. 21, text-fig. 20. 
intermediate, lateral and marginal; those of the submedian and intermediate pairs parallel, those of the lateral and marginal pairs inclined inward posteriorly. The median carina or crest of the telson is strong, the carinae of the next or lateral pair converge strongly posteriorly. The margin of the telson is so deficient that one can not make out the carina or the terminal denticles.

Measurements.-Length of abdominal segments beginning with the first: $11.2,10.7,10.7,11.3,13.6,9,17 \mathrm{~mm}$. (telson). Width of abdomen at fourth segment $31.7 \mathrm{~mm}$.

Occurrence.-California: Adelaide Quadrangle, central part about six miles west of Templeton, San Luis Obispo County; Monterey shales, middle Miocene series; one specimen showing the seven segments of the abdomen. Holotype in the University of California.

Relation.-In its size and general features this species approaches the Recent $P$. bigelowi ${ }^{63}$ from off the coast of southern California.

\section{BIBLIOGRAPHY}

1849. Dana, James D. United States Exploring Expedition. During the years 1838, 1839, 1840, 1841, 1842. Under the command of Charles Wilkes, U. S. N. Geology. Not dated [published 1849].

A new fossil crustacean described, Callianassa oregonensis, from the Miocene, p. 722 , atlas, pl. 17 , fig. 3 .

1864. GabB, W. M. Description of the Cretaceous Fossils. Geological Survey of California. Palaeontology. Vol. 1. Section 4.

Callianassa stimpsonii, new species, described (p. 57) and figured (pl. 9, fig. 1a-c). Types not extant. Impossible to identify figures, or to assign to Cretaceous or Eocene.

1867. - On the Subdivisions of the Cretaceous Formation in California. Proc. California Acad. Nat. Sci., vol. 3, 1866, pp. 301-306.

Lists Callianassa stimpsonii from both upper and lower Divisions of the Cretaceous, so-called.

1869. - Cretaceous and Tertiary Fossils. Geological Survey of California. Palaeontology. Vol. 2.

Cancer brewerii, new species, described (p. 1) and figured (pl. 1, fig. 1). Pliocene. Synonymous with Cancer productus Randall.

Crab carapace (p. 127), figured (pl. 19, fig. 1).

Shrimp, fragments of claws (p. 127, pl. 19, fig. 2-2b).

Callianassa stimpsonii Gabb 1864 (p. 127, pl. 19, fig. 3). Corrected figure of palm.

The last three are said to be Cretaceous and have not since been identified.

1871. Cope, E. D. On three extinct Astaci from the Fresh-Water Territory of Idaho. Proc. Amer. Philos. Soc., vol. 11, 1870, pp. 605-608.

Describes three new species of Astacus.

\footnotetext{
${ }^{63}$ Gonodactylus stylifierus Milne Edwards, Hist. Nat. Crust., vol. 2, 1837, p. 530, pl. 27, figs. 9-14, not Pseudosquilla stylifera (Lamarck, 1818) Dana. Pseudosquilla bigelowi Rathbun, Proe. U. S. Nat. Mus., vol. 38,1910 , p. 608.
} 
1882. Heilprin, Angelo. On the Age of the Tejon Rocks of California, and the occurrence of Ammonitic Remains in Tertiary Deposits. Proc. Acad. Nat. Sci. Philadelphia, vol. 34, pp. 196-214.

1888. Cooper, J. G. Catalogue of Californian Fossils. Seventh Ann. Rept. State Mineralogist for year ending Oct. 1, 1887, pp. 223-308.

Enumerates the two species to which Gabb had given specific names (pp. 227 and 271).

1895. Whiteaves, J. F. On some fossils from the Nanaimo group of the Vancouver Cretaceous. Trans. Roy. Soc. Canada, ser. 2, vol. 1, sec. 4, pp. 119-133.

One new crustacean described, Podocrates vancouverensis.

1896. Woodward, Henry. On some Podophthalmatous Crustacea from the Cretaceous Formation of Vancouver and Queen Charlotte Islands. Quart. Journ. Geol. Soc. London, vol. 52, pp. 221-228.

Describes the new species, Callianassa whiteavesii, Homolopsis richardsoni, Palaeocorystes harveyi, and Plagiolophus vancouverensis.

1900. - Further Notes on Podophthalmous Crustaceans from the Upper Cretaceous Formation of British Columbia, etc. Geol. Mag., new series, dec. 4 , vol. 7 , pp. 392-401.

Linuparus (Podocrates) vancouverensis, L. (P.) canadensis, and Eryma dawsoni, new species.

1900. - Further notes on Podophthalmous Crustaceans from the Upper Cretaceous Formation of British Columbia, etc. Geol. Mag., new series, dec. 4, vol. 7, pp. 433-435.

Describes four new species, Hoploparia westoni, H. bennetti, Enoploclytia minor, and Meyeria? harveyi, and notes occurrence of Callianassa whiteavesii.

1900. Whiteaves, J. F. Mesozoic fossils.-Vol. 1, pt. 4.-On some additional or imperfectly understood fossils from the Cretaceous rocks of the Queen Charlotte Islands, with a revised list of species from these rocks. Geol. Surv. of Canada, Ottawa, pp. 263-307.

Reproduces Woodward's description and figure of Homolopsis richardsoni.

1903. - Mesozoic fossils.-Vol. 1, pt. 5.-On some additional fossils from the Vancouver Cretaceous, with a revised list of the species therefrom. Geol. Surv. of Canada, Ottawa. Crustacea, pp. 315-326.

Describes a new species of Glyphaea, without specific name. Adds Linuparus atavus Ortmann to synonymy of Linuparus canadensis.

1903. Arnold, Ralph. The Paleontology and Stratigraphy of the Marine Pliocene and Pleistocene of San Pedro, California. Mem. California Acad. Sci., vol. 3, pp. 1-420, pls. 1-37.

Refers Pleistocene remains to Cancer breweri Gabb.

1905. Weaver, Charles E. Contribution to the Palaeontology of the Martinez Group. Univ. California Publ., Geol., vol. 4, No. 5.

Cancer? species. Pl. 13, fig. 11, p. 123. [Plagiolophus weaveri.]

1908. Rathbun, Mary J. Descriptions of Fossil Crabs from California. Proc. U. S. Nat. Mus., vol. 35, pp. 341-349.

Loxorhynchus grandis, Cancer fissus, new species, Branchiolambrus altus, new genus and species, and Archaeopus antennatus, new genus and species. Correction: After Etchegoin formation, read "Pliocene" instead of "Miocene." 
1916. Dickerson, Roy E. Stratigraphy and Fauna of the Tejon Eocene of California. Univ. California Publ., Geəl., vol. 9, No. 17, May 2.

Figures two crabs, Cancer (?), species $a$, p. 427, pl. 42, fig. 11. [Plagiolophus weaveri.]

Cancer (?), species $b$, p. 434, pl. 42 , fig. 12 . [Raninoides dickersoni.] 1916. Rathbun, Mary J. Description of a New Genus and Species of Fossil Crab from Port Townsend, Washington. Amer. Journ. Sci., vol. 41, pp. 344-346.

Branchioplax washingtoniana.

1917. - Description of a new species of crab from the California

Pliocene. Proc. U. S. Nat. Mus., vol. 53, pp. 451-452.

Cancer urbanus.

1924. Withers, Thomas H. Some Decapod Crustaceans (Callianassa and Ranina) from the Oligocene of Washington, U. S. A. Ann. Mag. Nat. Hist., ser. 9, vol. 14, July, 1924, pp. 121-127, pl. 4.

Two new species, Callianassa clallamensis and Ranina americana, described.

1925. Oldroyd, T. S. The Fossils of the Lower San Pedro Fauna of the Nob Hill cut, San Pedro, California. Proc. U. S. Nat. Mus., vol. 65, Art. 22, 1924 (issued Jan. 16, 1925), pp. 1-39, pls. 1-2.

On page 23 lists "Crab remains identified by Miss Mary J. Rathbun."

\section{EXPLANATION OF PLATES}

The photographs made for this report were taken by the United States Geological Survey and retouched by Miss Frances Wieser.

\section{Plate 1}

Fig. 1. Pyromaia tuberculata, abdomen of female, Spanish Bight, $\times 4$. The attached end is uppermost in the figure.

2. Chorilia, species, Deadman Island, right movable finger, outer view, $\times 4$.

3. Pinnixa eocenica, holotype, dorsal view of carapace, $\times 4$.

4. Same, rear view, $\times 4$.

5. Mesorhoea idae, paratype, Deadman Island, merus of right cheliped, inner surface, $\times 3$.

6. Same, upper surface, $\times 3$. Distal end at the right in the figure.

7. Same, outer surface, $\times 3$. Distal end at the right in the figure.

8. Mesorhoea idae, holotype, propodus of left cheliped, inner surface, $\times 3$.

9. Same, upper-outer surface, $\times 3$.

10. Same, lower-outer surface, $\times 3$.

11. Randallia pleistocenica, paratype, Nob Hill, merus of left cheliped, upper view, $\times 4$.

12. Randallia pleistocenica, holotype, carpus and propodus of left cheliped, lower (or outer) view, $\times 4$.

13. Randallia ornata, Signal Hill, right dactyl or movable finger, lower (or outer) view, $\times 4$.

14. Randallia ornata, Spanish Bight, right immovable finger, lower (or outer) view, $\times 4$.

15. Cycloxanthops novemdentatus, Rincon, right movable finger, $\times 1 / 2$.

16. Same, left immovable finger, $\times 1 \frac{1}{2}$. 
Plate 2

Loxorhynchus grandis, Canoas Creek, female, nat. size. After Rathbun

Fig. 1. Dorsal view.

2. Front view.

\section{Plate 3}

Loxorhynchus grandis, Canoas Creek, female, nat. size. After Rathbun

FIG. 1. Ventral view. Mandibles exposed, maxillae and maxillipeds lacking.

2. Rear view.

\section{Plate 4}

\section{After Rathbun}

FiG. 1. Loxorhynchus grandis, Canoas Creek, female, left profile, nat. size.

2. Branchiolambrus altus, holotype, dorsal view of carapace, $\times 2$.

3. Same, rear view, $\times 2$.

4. Archaeopus antennatus, male paratype, front view, $\times 2$.

5. Same, dorsal view, $\times 2$.

6. Same, ventral view, $\times 2$.

7. Archaeopus antennatus, female holotype, rear view, $\times 2$.

\section{Plate 5}

Archaeopus antennatus, female holotype, $\times 2$. After Rathbun

Fig. 1. Dorsal view.

2. Front view.

3. Ventral view.

\section{Plate 6}

\section{After Rathbun}

Fig. 1. Cancer fissus, carapace of holotype, dorsal view, $\times 2$.

2. Archaeopus antennatus, immature female, paratype, ventral view, $\times 2$.

3. Same, front view, showing palm, $\times 2$.

4. Same, rear view, $\times 2$.

\section{Plate 7}

Fig. 1. Uca oldroydi, male holotype, dorsal view, $\times 2$.

2. Same, ventral view, $\times 2$.

3. Hemigrapsus, species, Matanzas Creek, sternum and abdomen, $\times 1 \frac{1}{2}$.

\section{Plate 8}

Fig. 1. Uca hamlini, right chela of male, holotype, outer face, $\times 1 \frac{1}{2}$.

2. Eucrate martini, female holotype, ventral surface of body and impression of chelipeds, $\times 1 \frac{1}{2}$.

3. Reverse of the preceding, showing inside of ventral surface of body and outer view of chelipeds, $\times 1 \frac{1}{2}$. 


\section{Plate 9}

FIg. 1. Pilumnoplax carmanahensis, male holotype, right profile showing arm and wrist, $\times 1 \frac{11 / 2}{}$.

2. Same, dorsal view, $\times 1 \frac{1}{2}$.

3. Same, chelipeds, $\times 1 \frac{1}{2}$.

4. Same, left profile, showing merus of leg, $\times 1 \frac{1 / 2}{}$.

5. Plagiolophus weaveri, paratype, Martinez, antero-dorsal view to show orbits, $\times 1 \frac{1}{2}$.

6. Plagiolophus weaveri, holotype, dorsal view, $\times 1 \frac{1}{2}$.

7. Branchioplax washingtoniana, Bering Lake, dorsal view, $\times 11 \frac{1}{2}$.

\section{Plate 10}

Fig. 1. Pilumnoplax hannibalanus, male holotype, dorsal view, $\times 1 \frac{1}{2} ; d$, distal tooth, and $s$, subdistal tooth on right arm or merus; $f$, fifth or posterior tooth of antero-lateral margin of carapace.

2. Same, ventral view, $\times 1 \frac{1 / 2}{2} l$, , lobe of right manus overlapping dactylus; $m$, merus of first right ambulatory leg.

3. Same species, paratype $a$, dorsal view, $\times 1 \frac{1}{2}$.

4. Same, merus of left cheliped, $\times 2$.

5. Zanthopsis hendersonianus, holotype, dorsal view of carapace, nat. size.

6. Same species, paratype $a$, dorsal view of carapace, $\times 1 \frac{1}{2}$.

\section{Plate 11}

Fig. 1. Coeloma martinezensis, male holotype, ventral view, nat. size.

2. Same, dorsal view, nat. size.

3. Same, right chela, nat. size.

4. Lophopanopeus olearis, holotype, dorsal view, $\times 1 \frac{1}{2}$.

5. Persephona bigranulata, female holotype, ventral view, $\times 2$. The specimen is tipped a little to the right of the picture.

6. Same, dorsal view, $\times 2$.

7. Same, right profile, $\times 2$.

8. Same, rear view, $\times 2$.

Plate 12

Pilumnoplax soledadensis, male holotype, $\times 1 \frac{1}{2}$

Fig. 1. Dorsal view.

2. Impression of same, showing also movable finger of major chela.

Plate 13

Zanthopsis vulgaris, nat. size

FIG. 1. Male holotype, dorsal view.

2. Paratype, Holcomb (188), front view.

3. Paratype, female, Pachena Bay, ventral view.

Plate 14

Zanthopsis vulgaris, paratype, Holcomb (188), dorsal view, nat. size 
Plate 15

Cancer urbanus, holotype, dorsal view of carapace, $\times 2$, after Rathbun

\section{Plate 16}

Fig. 1. Cancer urbanus, Santa Monica, dorsal view of right wrist and palm, $\times 11 / 2$.

2. Cancer bainbridgensis, holotype, proximal end of dactylus of right cheliped, outer view, $\times 1 \frac{1}{2}$.

3. Same species, paratype, right (?) immovable finger, upper view, $\times 1 \frac{1}{2}$.

4. Cancer branneri, Signal Hill, right dactylus or movable finger, outer view, $\times 2$.

5. Cancer fissus, Section 24 , left manus, outer view, $\times 11 / 2$.

6. Same species and locality, another left manus, distal view, fingers broken off, $\times 1 \frac{1 / 2}{2}$; vertical length of fractures foreshortened.

7. Cancer gabbi, holotype, right manus, outer view, $\times 2$.

8. Same species, paratype, cross-section of right manus behind middle, $\times 2$.

9. Carcinides minor, holotype, carapace, dorsal view, $\times 4$.

10. Same species (331), right wrist, dorsal view, $\times 4$.

\section{Plate 17}

Fig. 1. Portunites insculpta, paratype, outer view of chela, $\times 4$.

2. Same species, holotype, dorsal view of carapace, $\times 2$.

3. Portunites triangulum, paratype (211), right manus, outer view, nat. size.

4. Same, dorsal view, nat. size.

5. Same species, holotype, dorsal view, $\times 1 \frac{1}{2}$.

6. Same, ventral view, $\times 1 \frac{1 / 2}{}$.

\section{Plate 18}

Fig. 1. Necrocarcinus hannae, holotype, dorsal view, $\times 2 ; l 0$, lower orbital tooth.

2. Same, right profile, $\times 2$.

3. Portunites alaskensis, paratype, Eugene, dorsal view, $\times 1 \frac{1}{2}$.

4. Same species, holotype, dorsal view, $\times 1 \frac{1}{2}$.

5. Callianassa stephensi, left immovable finger, holotype, outer view, $\times 3$.

6. Same, inner view, $\times 3$.

7. Same species, left movable finger, paratype, inner view, $\times 3$.

8. Same, outer view, $\times 3$.

\section{Plate 19}

Fig. 1. Calappa lanensis, holotype, dorsal view, $\times 1 \frac{1}{2}$.

2. Same, ventral view to show chela, $\times 1 \frac{1}{2}$.

3. Mursia yaquinensis, holotype, right antero-lateral profile of carapace, $\times 2$.

4. Same, right sternum, $\times 2$.

5. Same, right carapace, dorsal view, $\times 2$.

6. Mursia marcusana, holotype, dorsal view, $\times 2$.

7. Same species, left manus, Alki Point, $\times 2$. 
Plate 20

After Woodward except fig. 5, after Dickerson

FIG. 1. Plagiolophus vancouverensis, Comox River, carapace and arm, dorsal view, $\times 1 \frac{1}{2}$.

2. Same species, northwest side Hornby Island, carapace, dorsal view, $\times 1 \frac{1}{2}$.

3. Homolopsis richardsonae, Skidegate Inlet, dorsal view of carapace and fragments of some of the limbs, $\times 1 \frac{1}{2}$.

4. Palaeocorystes harveyi, dorsal view of carapace made from two type specimens, Vancouver Island and Hornby Island, nat. size.

5. Raninoides dickersoni, holotype, ventral view, $\times 2$.

6 and 7 . Callianassa whiteavesii, two left chelipeds, type-specimens, Comox River, $\times 11 / 2$.

8. Same species, Northwest Territories, nat. size. $a$. Cheliped. b. Distal portion of cheliped.

\section{Plate 21}

Fig. 1. Palehomola gorrelli, holotype, dorsal view, nat. size.

2. Same, outer view of left chela, nat. size.

3. Graptocarcinus (?), species (353565), dorsal view, $\times 3$. c. Corneal end. $e$. Base of eyestalk.

4. Ranidina willapensis, holotype, right profile, nat. size.

5. Same, dorsal view.

\section{Plate 22}

Fig. 1. Ranina tejoniana, holotype, dorsal view, nat. size.

2. Same, ventral view, nat. size.

3. Portunites alaskensis, chela (253), $\times 2$.

4. Raninoides lewisanus, holotype, dorsal view, $\times 11 \frac{1}{2}$.

5. Raninoides vaderensis, holotype, dorsal view, $\times 1 \frac{1}{2}$.

6. Raninoides washburnei, holotype, dorsal view, $\times 11 \frac{1}{2}$.

\section{Plate 23}

Fig. 1. Ranina americana, N. Pac. 167, ventral view, nat. size.

2. Same, dorsal view, nat. size.

3. Same species and locality, another specimen, ventral view, nat. size.

4. Same, dorsal view, nat. size.

5. Raninoides asper, holotype, dorsal view of left side of carapace, $\times 4$.

6. Raninoides fulgidus, holotype. dorsal view, $\times 1 \frac{1}{2}$.

\section{Plate 24}

Fig. 1. Dardanus subaequalis, holotype, right chela, $\times 2$.

2. Same, left chela, $\times 2$.

3. Paguristes, species, California, chela, $\times 2$.

4. Raninoides eugenensis, holotype, dorsal view, $\times 1 \frac{1}{2}$.

5. Dardanus arnoldi, holotype, right movable finger, ventral view, $\times 3.3$.

6. Same, outer-dorsal view, $\times 3.8$.

7. Same species, paratype, left wrist, outer view, $\times 3$.

8. Same, inner view, $\times 3$.

9. Eumorphocorystes naselensis, holotype, dorsal view, nat. size.

10. Same, right profile, nat. size. $h$. Hepatic angle. S. Lateral spine. 
Plate 25

Fig. 1. Callianassa incerta, holotype, right manus, outer view, $\times 3$.

2. Same, inner view, $\times 3$.

3. Same, cross-section at base of fingers, $\times 3$.

4. Same species, paratype, left wrist, outer view, $\times 3$.

5. Callianassa kewana, holotype, right manus, outer view, $\times 2$.

6. Same, inner view, $\times 2$.

7. Same, distal end showing base of fingers, $\times 2$.

8. Callianassa umpquaensis, paratype (324), right movable finger, outer view, $\times 11 / 2$.

9. Same species, paratype, left major wrist, outer view, $\times 1 \frac{1}{2}$.

10. Same species, holotype, propodus of right cheliped, outer view, $\times 11 / 2$.

11. Same species, paratype, right major manus, inner view, $\times 1 \frac{1}{2}$.

12. Same species, propodus of left cheliped, paratype, outer view, $\times 11 / 2$.

Plate 26

Fig. 1. Callianassa cowlitzensis, holotype, right manus, inner view $\times 1 \frac{1}{12}$. $t$. Spot where tooth projects into interdigital gape.

2. Same, outer view, $\times 1 \frac{1}{2}$. $t$. Same as in fig. 1 .

3. Same species, right wrist (341), outer view, $\times 11 / 2$.

4. Callianassa fresnoensis, holotype, left manus, proximal end, $\times 3$.

5. Same, inner view, $\times 3$.

6. Callianassa clallamensis, left manus (120), outer view, $\times 1 \frac{1}{2}$.

7. Same species, right manus and portion of wrist $(120)$, outer view, $\times 11 / 2$.

8. Same species, left manus with stump of dactylus (120), outer view, $\times 1 \frac{1}{2}$.

9. Same species, right manus $(120)$, outer view, $\times 1 \frac{1}{2}$.

10. Same species, left manus (281), inner view, $\times 11 / 2$.

11. Same specimen, outer view, $\times 1 \frac{1 / 2}{}$.

12. Same specimen, cross-section at base of fingers, $\times 1 \frac{1}{2}$.

\section{Plate 27}

FIg. 1. Callianassa twinensis, left cheliped, paratype $e$, outer view, $\times 1 \frac{1}{2}$.

2 . Same species, portion of right cheliped, holotype, outer view, $\times 2$.

3. Same species, portion of right chela, paratype $a$, inner view, $\times 2$.

4. Same species, right chela of female, paratype $d$, outer view, $\times 1 \frac{1}{2}$.

5. Callianassa bandonensis, right manus, holotype, inner view, $\times 2$.

6. Same, outer view, $\times 2$.

7. Same species, right manus, paratype $b$, outer view, $\times 2$.

8. Same species, left manus, paratype $a$, outer view, $\times 2$.

Plate 28

Fig. 1. Callianassa porterensis, right major propodus with finger, paratype $d$, inner view, $\times 2$.

2. Same species, right minor propodus with finger, paratype $e$, outer view, $\times 1 \frac{1}{2}$.

3. Same species, left major propodus with finger, paratype $c$, outer view, $\times 2$.

4. Same species, left major propodus with finger, holotype, outer view, $\times 2$. 
Fig. 5. Same species, left minor propodus with finger, paratype $b$, outer view, $\times 2$.

6. Callianassa oregonensis, right wrist $(245)$, outer view, $\times 1 \frac{112}{2}$.

7. Same species, left chela of female (5458), outer view, $\times 11 \frac{1}{2}$.

8. Same species, right chela of male (5456), inner view, $\times 11 \frac{1}{2}$.

9. Same species, left minor cheliped (5454), outer view, $\times 1 \frac{1 / 2}{2}$.

10. Blepharipoda brucei, left merus, paratype, outer-upper view, $\times 4$.

11. Same species, right manus, holotype, outer view, $\times 4$.

\section{Plate 29}

Fig. 1. Upogebia eocenica, holotype, dorsal view of carapace, $\times 4$. $s$. Orbital spine.

2. Same species, paratype $h$, right palm, inner view, showing oblique striae, $\times 4$.

3. Callianassa longimana, right immovable finger, Spanish Bight, inner side $\times 6$.

4. Same, outer side, $\times 3$.

5. Same species, Deadman Island. $a$. Right movable finger, inner side, $\times 3$. b. Left immovable finger, inner side, $\times 3$.

6. $a$ and $b$. Same specimens, outer side, $\times 3$.

7. Astacus chenoderma, Eldorado, No. 5, abdomen (segments 1-6), right profile, and fragments of legs, $\times 1 \frac{1}{2}$.

\section{Plate 30}

\section{Upogebia eocenica}

FIG. 1. Paratype $e, \times 4$. 3- $\%$. Abdominal segments. $m$. Manus. s. Striae on inner surface of hand. $t f$. Tail fan.

2. Paratype $f, \times 4$. 5- $\%$. Abdominal segments. $t f$. Tail fan.

3. Paratype $h$, right palm, top view, $\times 4$.

4. Paratype $c$, right propodus of cheliped and part of movable finger, $\times 6$.

\section{Plate 31}

\section{Astacus chenoderma, $\times 1 \frac{1}{2}$}

Fig. 1. Eldorado, No. 3, portion of carapace, left profile.

2. Vale, No. 4, carpus and manus of right minor cheliped, dorsal view.

3. Eldorado, No. 7, right minor chela, ventral view.

4. Eldorado, No. 8, left immovable finger, dorsal view.

5. Eldorado, No. 6, right major cheliped, dorsal view.

Plate 32

Astacus chenoderma, $\times 1 \frac{1}{2}$

Fig. 1. Vale, No. 3, abdomen, dorsal view.

2. Eldorado, No. 4, abdomen and tail fan, dorsal view. 
Plate 33

Astacus chenoderma, $\times 1 \frac{1}{2}$

Fig. 1. Eldorado, No. 2, rostral end, dorsal view.

2. Eldorado, No. 9, merus of cheliped.

3. Eldorado, No. 1, anterior part of carapace with rostrum, dorsal view.

4. Snake River Valley, right (major?) cheliped, lower view.

5. Vale, No. 2, portion of carapace and abdomen (2-7 segments), in profile.

Plate 34

\section{Astacus chenoderma, $\times 11 / 2$}

Fra. 1. Vale, No. 1, anterior end of carapace and portion of left cheliped, dorsal view,

2. Same specimen in left profile.

3. Eldorado, No. 10, ambulatory legs.

\section{Plate 35}

\section{After Woodward}

Fig. 1. Eryma dawsoni, Hornby Island, profile of specimen embedded in nodule, nat. size.

2. Podocratus canadensis, Hornby Island, under side of cephalothorax, nat. size.

\section{Plate 36}

Podocratus canadensis, Highwood River, dorsal view of type-specimen, after Woodward

Plate 37

Podocratus vancouverensis, nat. size, after Woodward

FIG. 1. Dorsal view of carapace with some ambulatory legs, Puntledge River.

2. Dorsal view of carapace and abdomen with some ambulatory legs, Hornby Island.

3. Inner surface of thorax, with mandibles $(m)$ and anbulatory legs; also bases of antennules and upper surface of abdominal segments, Puntledge River.

\section{Plate 38}

Fig. 1. Chloridella sonomana, holotype, last four abdominal segments (3-6), $\times 1 \frac{1}{2}$.

2. Same specimen, portion of carapace $(c)$, thoracic (5-8) and first two abdominal $(1,2)$ segments, $\times 1 \frac{1}{2}$.

3. Pseudosquilla adelaidensis, holotype, abdomen, nat. size.

4. Callianassa knapptonensis, right major manus, holotype, outer view, $\times 2$.

Plate 39

Zanthopsis sternbergi, right cheliped, holotype, $\times 2$

Fig. 1. Merus, outer view.

2. Carpus, outer view.

3. Chela, outer view.

4. Carpus and chela, dorsal view. 


\section{ADDENDUM}

While this paper was going through the press a specimen was received which is apparently congeneric with Macrocheira kaempferi, the giant crab of Japan which inhabits deeper waters off shore, and is not known in America. The species below is the second one to be described in this genus.

\section{Family MAJIDAE}

\section{Genus MACROCHEIRA de Haan}

Maerocheira de HAAN, Fauna Japon, 1839, pp. 79 and 88 ; type, M. kaempferi (de Haan).

Carapace subtriangular. Rostrum long, two divergent spines. Preocular spine small. Basal antennal article not reaching front. Merus of outer maxillipeds elongate, rounded at distal end. Legs very long.

Oligocene; Recent.

MACROCHEIRA TEGLANDI, new species

Description.-Carapace high in the middle, sloping down on the sides and behind; front deflexed, rostrum invisible. Carapace broad, greatest width nearly equal to postfrontal length. Posterior two-
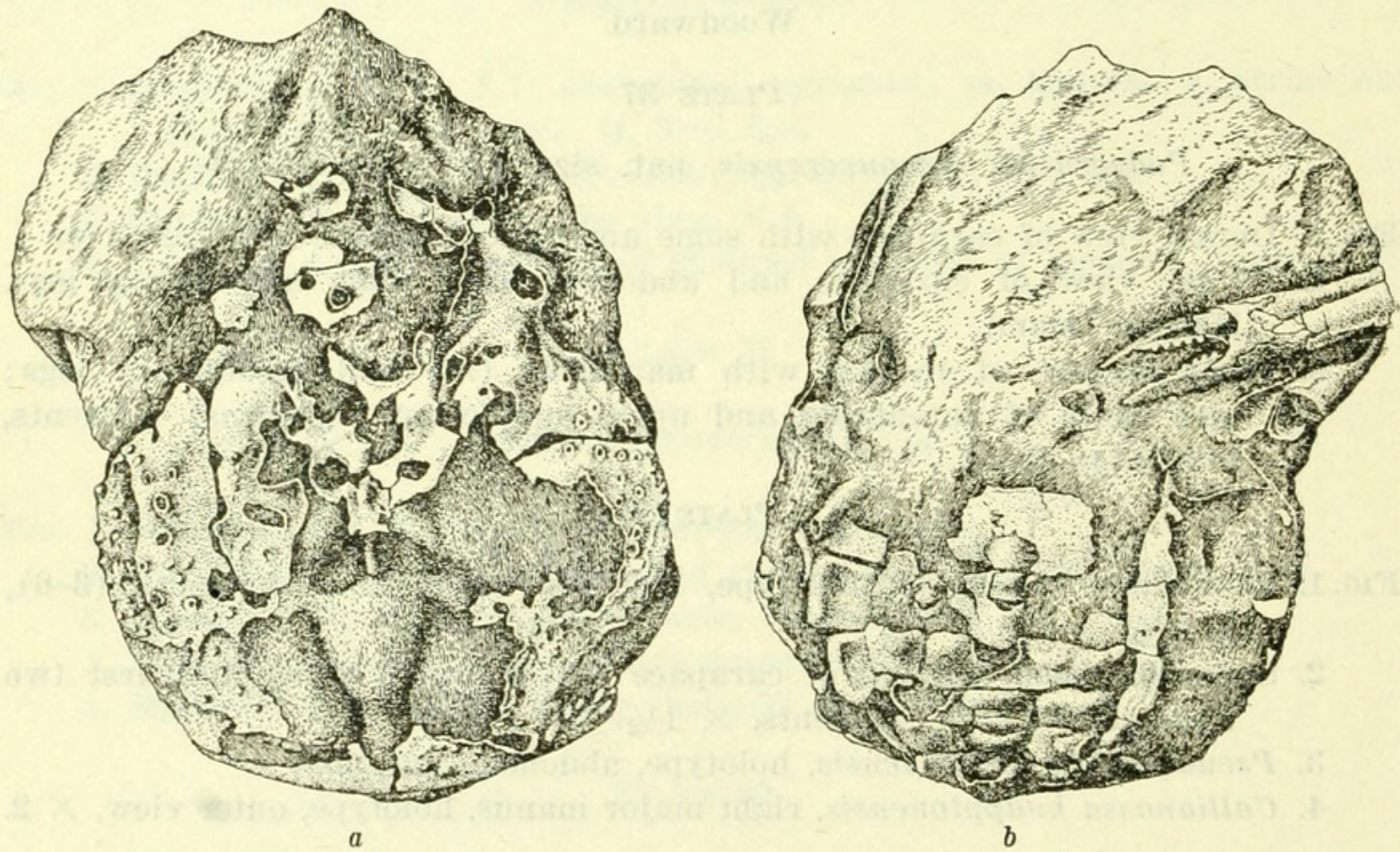

Fig. 6.-Macrocheira teglandi, female, holotype. a. Dorsal view. $b$. ventral view, SHOWING CGELIPED, STERNUM, AND ABDOMEN

thirds transversely broad-oval. Branchial regions nearly meeting on median line, a deep and broad hollow being the inner angle of each. Cardiac region urnshaped. Hepatic region short and high. Orbital region half the carapace width; anterior margin of inner, upper spine nearly transverse; outer spine stout at base, remainder broken 
off. Carapace punctate, posterior and posterolateral portions tuberculate. Sternum very broad, the plates extended laterally over bases of ambulatory legs. Abdomen of adult female considerably narrower than sternum, divided by two longitudinal furrows into three parts; middle part crossed transversely on the second to fifth segments, inclusive, by a high ridge; lateral parts with a large tubercle on the third to fifth segments, that on the fifth segment the largest.

Chelipeds of female of moderate length, narrow, palm not swollen but widening slightly toward the distal end. Fingers slender, shorter than palm, toothed on prehensile edges, dark color covering almost the distal half, running along either edge but not so far in the middle.

Measurements.-Female holotype, length of carapace from posterior margin to inner base of inner orbital spine $54.3 \mathrm{~mm}$; width of carapace $51 \mathrm{~mm}$.

Occurrence.-Washington: Conglomerate on beach just east of first Geodetic Survey mark beyond the first point east of East Twin River; 1926; Oligocene series; Nellie M. Tegland, collector. Holotype in University of California.

Relation.-Differs from M. kaempferi in its greater fronto-orbital distance, smoother carapace, more transverse inner orbital spine. 
(4) 


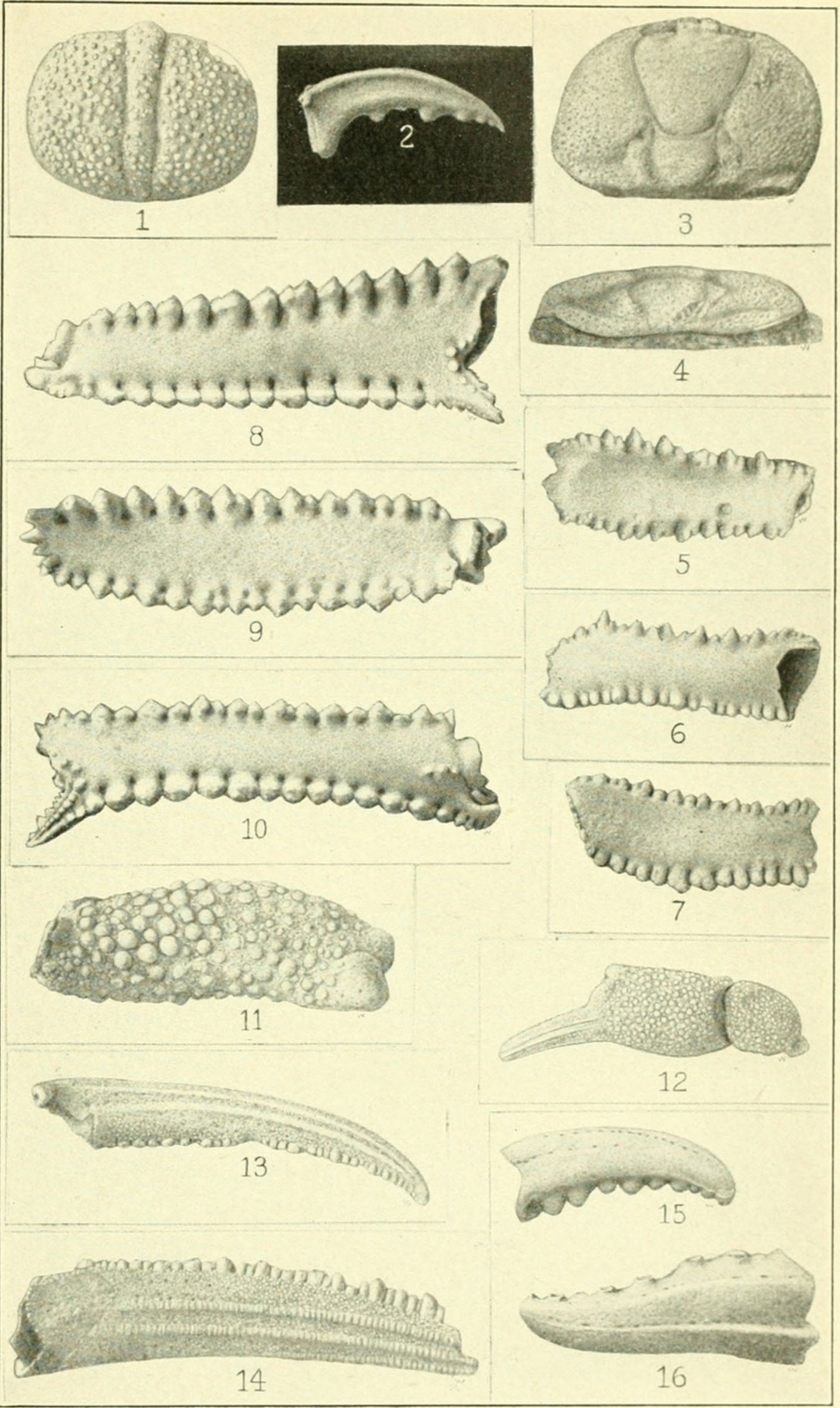

I, 2, 5-10. OXYrhyncha. (PAges 22, 25, 27.) 3, 4. Pinnixa. (PAge 34. II-I4. Randallia. (Pages 76, 77.) I5, 16. Cycloxanthops. (PAge 58) $3020-26-11 \quad$ FOR EXPLANATION OF PLATE SEE PAGE 140 

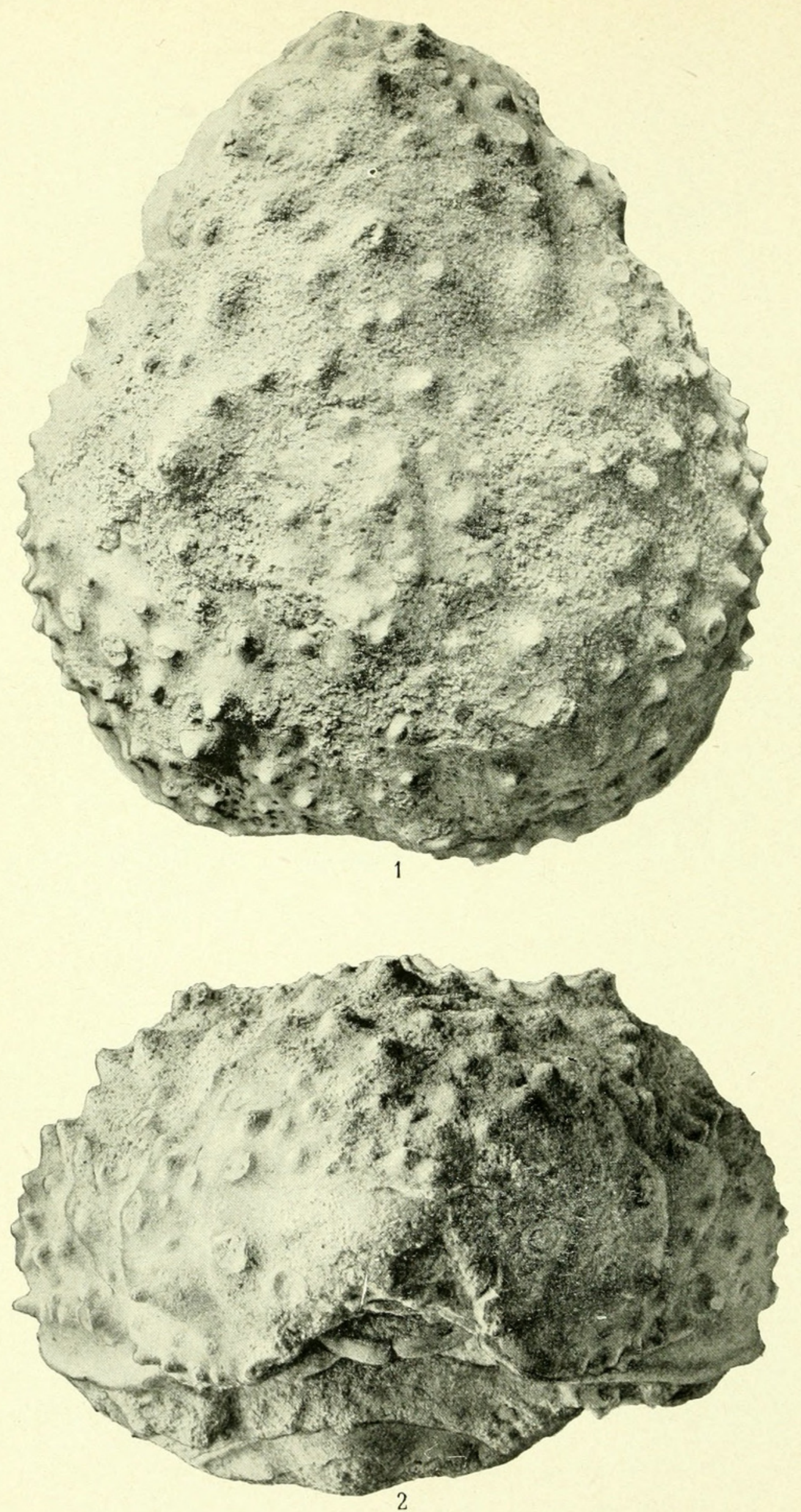

LOXORHYNCHUS GRANDIS. (PAGE 24)

For explanation of plate see page 14 I 

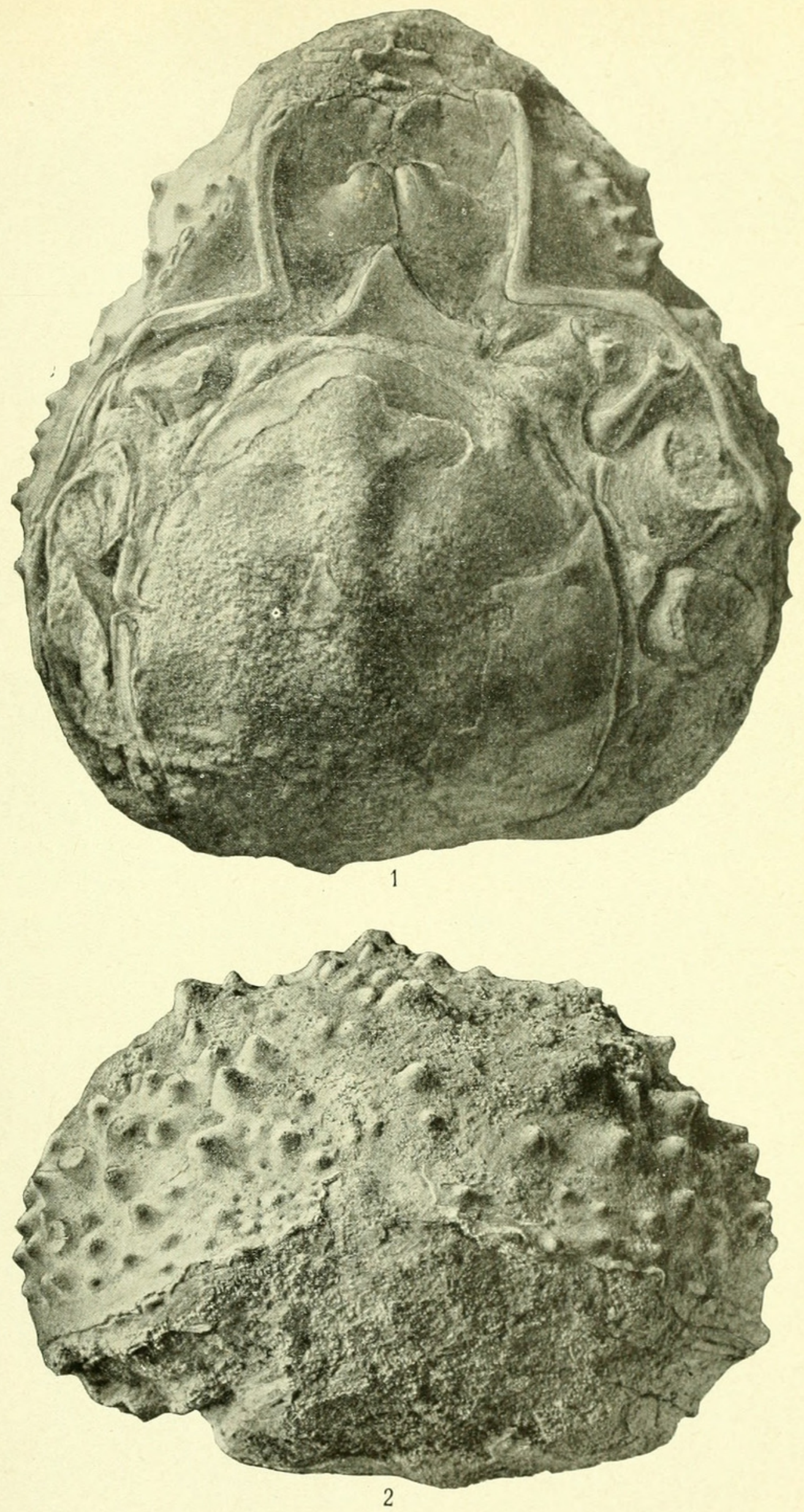

LOXORHYNCHUS GRANDIS. (PAGE 24)

For explanation of plate see Page 14 | 

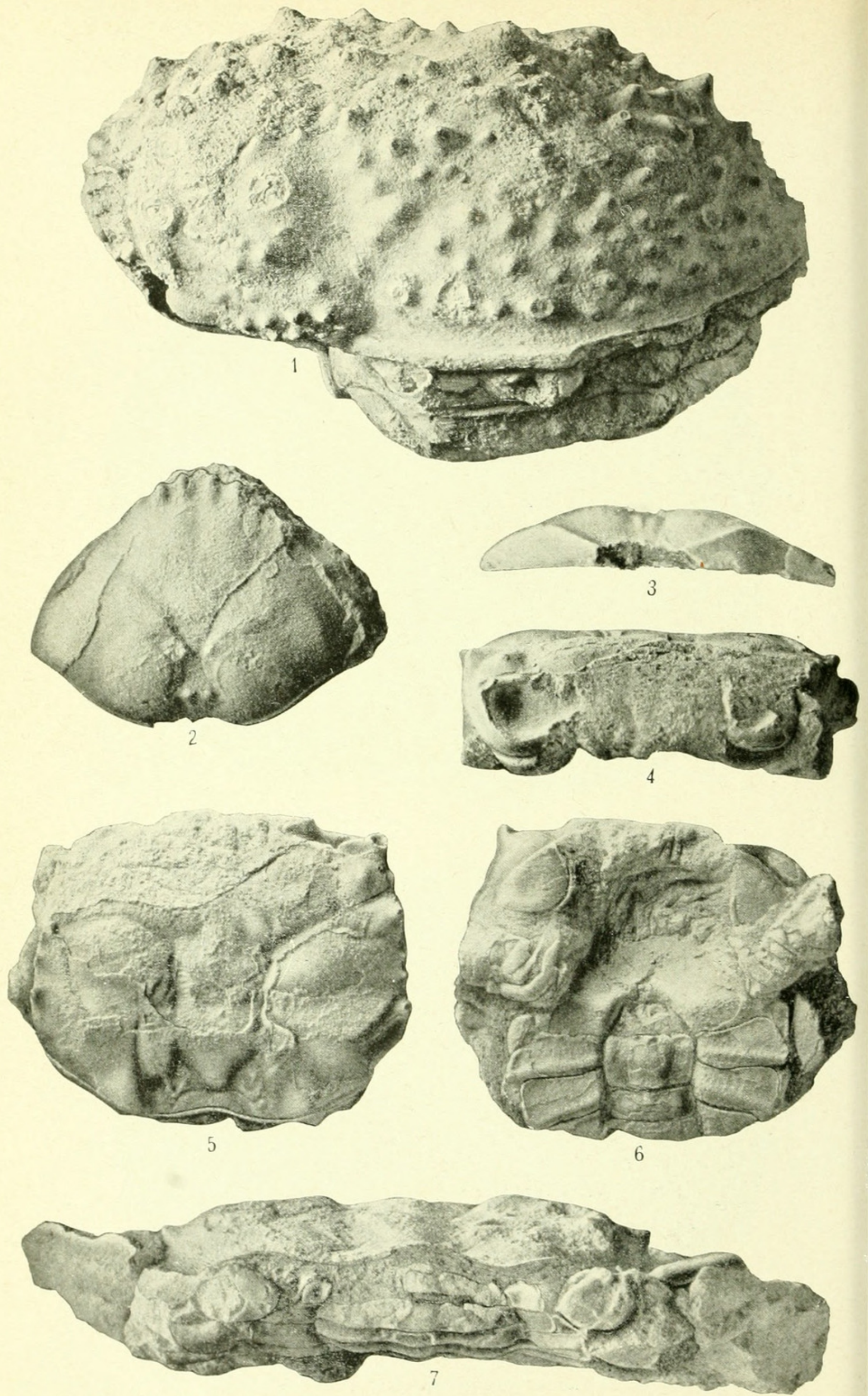

I. LOXORHYNCHUS 'GRANDIS. (PAgE!24.) 2, 3. Branchiolambrus altus. (PAge 65.) 4-7. Archaeopus antennatus. (PAge 3I) 

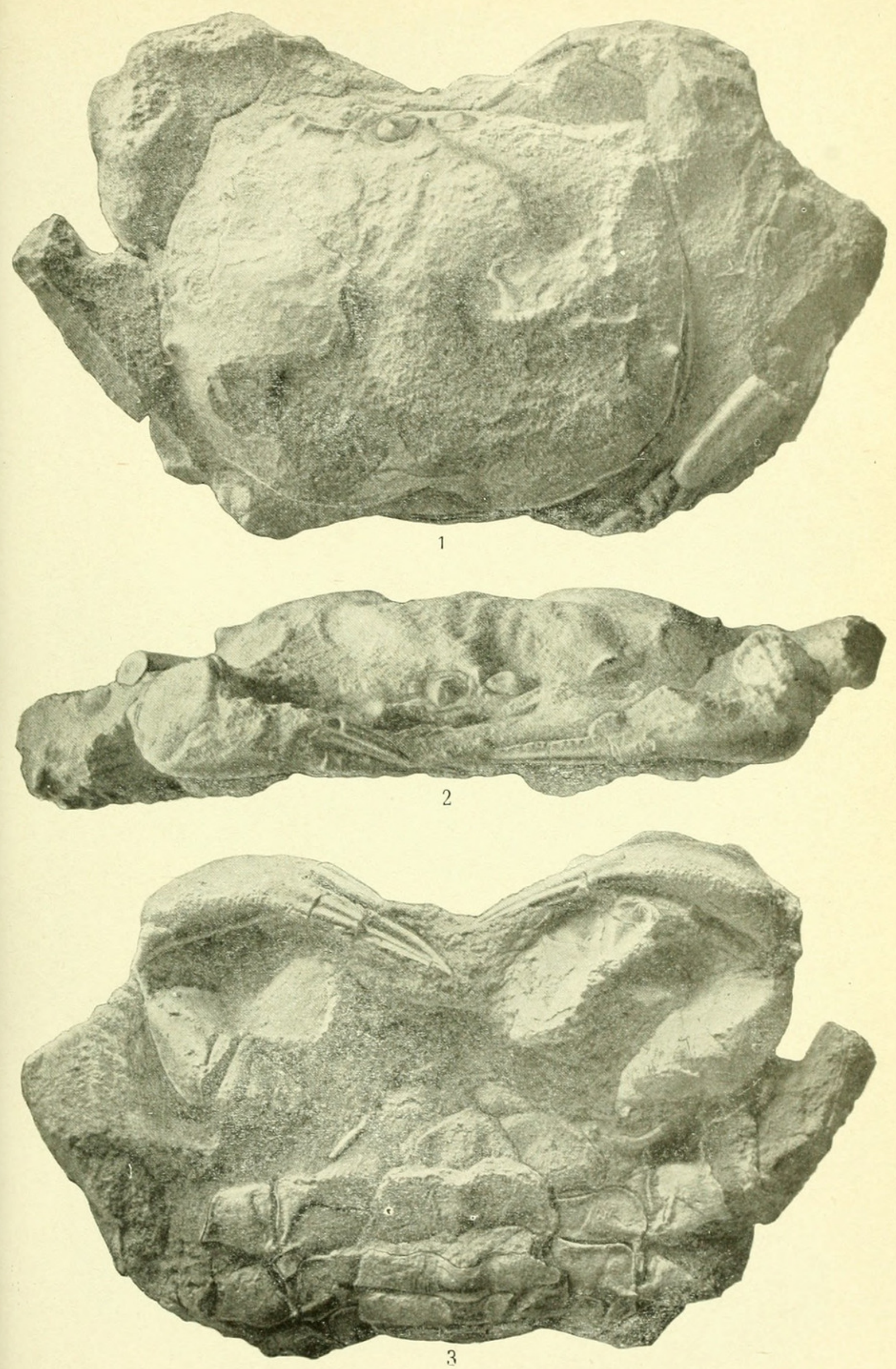

Archaeopus antennatus. (PAge 3I)

For explanation of Plate see page 14 I 


\section{$2 \mathrm{BHL}$ Biodiversity Heritage Library}

Rathbun, Mary Jane. 1926. "The fossil stalk-eyed Crustacea of the Pacific Slope of North America." Bulletin 138, 1-155.

https://doi.org/10.5479/si.03629236.138.i.

View This Item Online: https://www.biodiversitylibrary.org/item/34578

DOI: https://doi.org/10.5479/si.03629236.138.i

Permalink: https://www.biodiversitylibrary.org/partpdf/22115

\section{Holding Institution}

Smithsonian Libraries

\section{Sponsored by}

Smithsonian

\section{Copyright \& Reuse}

Copyright Status: NOT_IN_COPYRIGHT

This document was created from content at the Biodiversity Heritage Library, the world's largest open access digital library for biodiversity literature and archives. Visit BHL at https://www.biodiversitylibrary.org. 